Prepared in cooperation with the Colorado School of Mines, Center for Environmental Risk Assessment; National Institutes of Health/National Institute of Environmental Health Sciences (NIH/NIEHS), National Toxicology Program Laboratory; University of Illinois at Chicago, School of Public Health; U.S. Environmental Protection Agency, National Exposure Research Laboratory; U.S. Environmental Protection Agency, National Health and Environmental Effects Laboratory

\title{
Methods Used for the Collection and Analysis of Chemical and Biological Data for the Tapwater Exposure Study, United States, 2016-17
}

Open-File Report 2018-1098 



\section{Methods Used for the Collection and Analysis of Chemical and Biological Data for the Tapwater Exposure Study, United States, 2016-17}

By Kristin M. Romanok, Dana W. Kolpin, Shannon M. Meppelink, Maria Argos, Juliane B. Brown, Michael J. DeVito, Julie E. Dietze, Carrie E. Givens, James L. Gray, Christopher P. Higgins, Michelle L. Hladik, Luke R. Iwanowicz, Keith A. Loftin, R. Blaine McCleskey, Carrie A. McDonough, Michael T. Meyer, Mark J. Strynar, Christopher P. Weis, Vickie S. Wilson, and Paul M. Bradley

Prepared in cooperation with the Colorado School of Mines, Center for Environmental Risk Assessment; National Institutes of Health/National Institute of Environmental Health Sciences (NIH/NIEHS), National Toxicology Program Laboratory; University of Illinois at Chicago, School of Public Health; U.S. Environmental Protection Agency, National Exposure Research Laboratory; U.S. Environmental Protection Agency, National Health and Environmental Effects Laboratory

Open-File Report 2018-1098

\section{U.S. Department of the Interior U.S. Geological Survey}




\title{
U.S. Department of the Interior \\ RYAN K. ZINKE, Secretary
}

\author{
U.S. Geological Survey \\ James F. Reilly II, Director
}

U.S. Geological Survey, Reston, Virginia: 2018

For more information on the USGS - the Federal source for science about the Earth, its natural and living resources, natural hazards, and the environment-visit https://www.usgs.gov or call 1-888-ASK-USGS (1-888-275-8747).

For an overview of USGS information products, including maps, imagery, and publications,

visit https://store.usgs.gov.

Any use of trade, firm, or product names is for descriptive purposes only and does not imply endorsement by the U.S. Government.

Although this information product, for the most part, is in the public domain, it also may contain copyrighted materials as noted in the text. Permission to reproduce copyrighted items must be secured from the copyright owner.

Suggested citation:

Romanok, K.M., Kolpin, D.W., Meppelink, S.M., Argos, M., Brown, J.B., DeVito, M.J., Dietze, J.E., Givens, C.E., Gray, J.L., Higgins, C.P., Hladik, M.L., Iwanowicz, L.R., Loftin, K.A., McCleskey, R.B., McDonough, C.A., Meyer, M.T., Strynar, M.J., Weis, C.P., Wilson, V.S., and Bradley, P.M., 2018, Methods used for the collection and analysis of chemical and biological data for the Tapwater Exposure Study, United States, 2016-17: U.S. Geological Survey Open-File Report 2018-1098, 79 p., https://doi.org/10.3133/ofr20181098. 


\section{Acknowledgments}

The authors would like to extend their appreciation to fellow colleagues who collected field samples and offered additional support to make this project successful. Marc Cox at the University of Texas at El Paso provided the yeast Strain MCY-105 used in the screening for glucogenicity performed at the U.S. Geological Survey National Fish Health Research Laboratory in West Virginia.

We appreciate the helpful reviews of the manuscript by Heather Heckathorn and David Fazio, both with the U.S. Geological Survey. 



\section{Contents}

Acknowledgments ……...................................................................................................................

Abstract

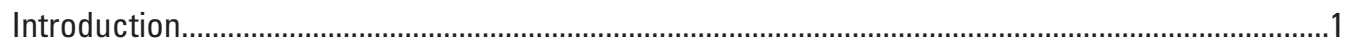

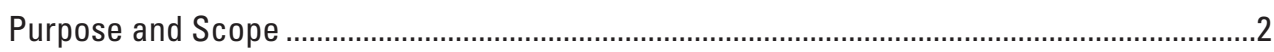

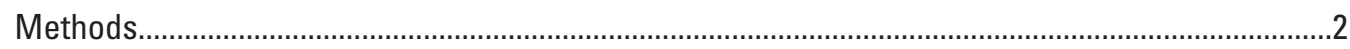

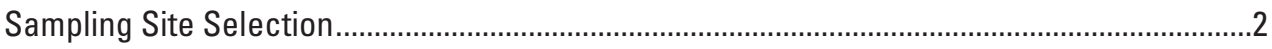

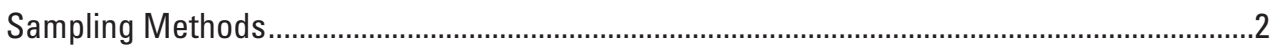

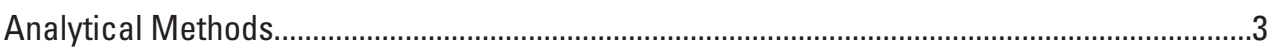

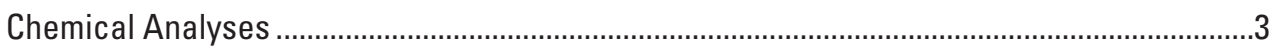

National Water Quality Laboratory (NWOL), Denver, Colorado ............................................

Steroid Hormones and Related Compounds (Phase I only)........................................3

Human-Use Pharmaceuticals, Pharmaceutical Metabolites, and Selected Polar Organic Compounds (Phases I and II)...................................

Heat Purgeable Volatile Organic Compounds (Phase II only)....................................4

Ambient Purgeable Volatile Organic Compounds (Phases I and II).........................4

Selected Trace Elements (Phases I and II) and Nitrate plus Nitrite (Phase II only) .............................................................................................

Per- and Polyfluroalkyl Substances (PFAS, Phases I and II)....................................

USGS Organic Geochemistry Research Laboratory (OGRL), Lawrence, Kansas .............4

Glyphosate, Glufosinate, and Aminomethylphosphonic acid

(Phase I only) ...........................................................................................

Steroid Hormones, Hormone Conjugates, and Phytoestrogens (Phases I and II)...5

Acetamide Herbicides and Degradation Products

(Phases I and II) ..................................................................................

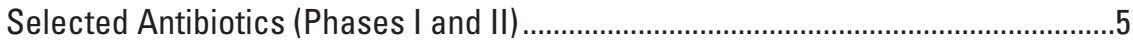

Cyanotoxin Screening (Phase II only) ....................................................................

USGS Organic Chemistry Research Laboratory (OCRL), Sacramento, California .............5

Pesticides and Pesticide Degradates (Phases I and II) ............................................

Diuron and Diuron Degradates and Neonicotinoid Insecticides

(Phases I and II) .....................................................................................

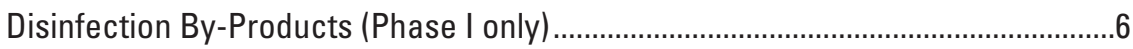

USGS Redox Chemistry Laboratory (RCL), Boulder, Colorado (Phase II only)...................6

EPA National Exposure Research Laboratory (NERL; Phases I and II) ............................6

Colorado School of Mines (Phases I and II)................................................................

High-Performance Liquid Chromatography ..........................................................

Quadrapole Time of Flight-Mass Spectrometry (QTOF-MS)...................................7

Data Acquisition Parameters..................................................................................

Quantitative Analysis ....................................................................................

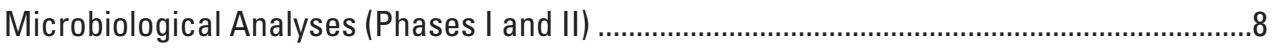

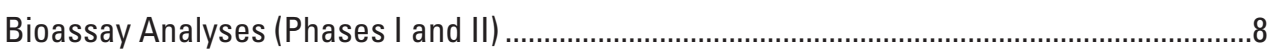

Extraction Method (Phases I and II) ........................................................................

USGS National Fish Health Research Laboratory (NFHRL) .............................................

EPA National Health and Environmental Effects Laboratory (NHEERL) ............................9

Results 
References Cited.

Appendix 1. Target analytes and internal standards used for quantitation of per- and polyfluorinated alkyl substances analyzed at the Colorado School of Mines, Golden, Colorado

Appendix 2. Recoveries of target analytes in 7-milliliter in-vessel spike tests of per- and polyfluorinated alkyl substances analyzed at the Colorado School of Mines, Golden, Colorado

Appendix 3. Calibration range, limit of quantitation, linear fit $\left(\mathrm{r}^{2}\right)$, and weighting type of calibration curves for target analytes of per- and polyfluorinated alkyl substances analyzed at the Colorado School of Mines, Golden, Colorado...

\section{Tables}

1. Site information for samples collected as part of the U.S. Geological Survey (USGS) Environmental Health Mission Area, Infrastructure Project, Tapwater Exposure Study, 2016-17

2. Chemical compound information for analyses performed by various laboratories for the U.S. Geological Survey, Environmental Health Mission Area, Infrastructure Project, Tapwater Exposure Pilot Study, 2016-17

2. Chemical compound information for analyses performed by various laboratories for the U.S. Geological Survey, Environmental Health Mission Area, Infrastructure Project, Tapwater Exposure Pilot Study, 2016-17 


\section{Conversion Factors}

International System of Units to U.S. customary units

\begin{tabular}{lcl}
\hline \multicolumn{1}{c}{ Multiply } & By & \multicolumn{1}{c}{ To obtain } \\
\hline centimeter $(\mathrm{cm})$ & Length & \\
millimeter $(\mathrm{mm})$ & 0.3937 & inch (in.) \\
\hline & 0.03937 & inch (in.) \\
\hline liter (L) & Volume & \\
liter (L) & 33.81402 & ounce, fluid (fl. oz) \\
\hline
\end{tabular}

Temperature in degrees Celsius $\left({ }^{\circ} \mathrm{C}\right)$ may be converted to degrees Fahrenheit $\left({ }^{\circ} \mathrm{F}\right)$ as follows:

$$
{ }^{\circ} \mathrm{F}=\left(1.8 \times{ }^{\circ} \mathrm{C}\right)+32 .
$$

\section{Supplemental Information}

Specific conductance is given in microsiemens per centimeter at 25 degrees Celsius $(\mu \mathrm{S} / \mathrm{cm}$ at $\left.25^{\circ} \mathrm{C}\right)$.

Concentrations of chemical constituents in water are given either in milligrams per liter ( $\mathrm{mg} / \mathrm{L}$ ), micrograms per liter $(\mu \mathrm{g} / \mathrm{L})$, or nanograms per liter $(\mathrm{ng} / \mathrm{L})$.

\section{Abbreviations}

${ }^{\circ} \mathrm{C}$

degrees Celsius

BLYAS

Bioluminescent Yeast Androgen Screen

BLYES

Bioluminescent Yeast Estrogen Screen

CSM

Colorado School of Mines

$\mathrm{Da}$

Dalton

DAI

direct aqueous injection

DCM

dichloromethane

DLBLK detection level, determined using blank data

DLDOC detection limit, by the DOCALC procedure

ELISA enzyme-linked immunosorbent assays

EPA

U.S. Environmental Protection Agency

ESI electrospray ionization

Et-FOSA $\mathrm{N}$-ethylperfluoro-1-octanesulfonamide perfluoro-1-octanesulfonamide

FOSAA perfluoro-1-octanesulfonamidoacetic acid 


\begin{tabular}{|c|c|}
\hline FTA & fluorotelomer acid \\
\hline FTS & fluorotelomer sulfonate \\
\hline GC/MS-MS & gas chromatography/tandem mass spectrometry \\
\hline GFAAS & graphite furnace atomic absorption spectrometry \\
\hline GS/MS & gas chromatography/mass spectrometry \\
\hline HDPE & high-density polyethylene \\
\hline HLB & hydrophilic lipophilic balanced \\
\hline HPLC/MS-MS & high-performance liquid chromatography/tandem mass spectrometry \\
\hline ICP-MS & inductively coupled plasma-mass spectrometry \\
\hline ICP-OES & inductively coupled plasma-optical emissions spectrometry \\
\hline IRL & interim reporting level \\
\hline IS & internal standards \\
\hline LC/MS-MS & liquid chromatography/tandem mass spectrometry \\
\hline LOO & limit of quantitation \\
\hline Me-FOSA & N-methylperfluoro-1-octanesulfonamide \\
\hline $\mathrm{mg} / \mathrm{L}$ & milligrams per liter \\
\hline $\mathrm{mL}$ & milliliter \\
\hline $\mathrm{mm}$ & millimeter \\
\hline MRL & minimum reporting level \\
\hline $\mathrm{ms}$ & milliseconds \\
\hline MS-MS & tandem mass spectrometry \\
\hline NERL & National Exposure Research Laboratory \\
\hline NFHRL & National Fish Health Research Laboratory \\
\hline $\mathrm{ng} / \mathrm{L}$ & nanograms per liter \\
\hline NHEEL & National Health and Environmental Effects Laboratory \\
\hline $\mathrm{NIH} / \mathrm{NIEHS}$ & National Institutes of Health/National Institute of Environmental Health Sciences \\
\hline NTP & National Toxicology Program \\
\hline NWQL & National Water Quality Laboratory \\
\hline OCRL & Organic Chemistry Research Laboratory \\
\hline OGRL & Organic Geochemistry Research Laboratory \\
\hline PETG & polyethylene terephthalate glycol \\
\hline PFAS & per- and polyfluoroalkyl substances \\
\hline PFBA & perfluorobutyrate acid \\
\hline PFDoA & perfluoro-n-dodecanoic acid \\
\hline PFDoS & perfluoro-1-dodecanesulfonate \\
\hline
\end{tabular}




\begin{tabular}{|c|c|}
\hline PFHpA & perfluoro-n-heptanoic acid \\
\hline PFHpS & perfluoro-1-heptanesulfonate \\
\hline PFODA & perfluoro-n-octadecanoic acid \\
\hline PFPeA & perfluoro-n-pentanoic acid \\
\hline PFPeS & perfluoro-1-pentanesulfonate \\
\hline PFTeDA & perfluoro-n-tetradecanoic acid \\
\hline $\mathrm{pg}$ & picograms \\
\hline $\mathrm{pH}$ & potential of hydrogen \\
\hline ppm & parts per million \\
\hline psi & pounds per square inch \\
\hline $\mathrm{QA} / \mathrm{QC}$ & quality assurance and quality control \\
\hline $\mathrm{RCL}$ & Redox Chemistry Laboratory \\
\hline RLDQC & reporting limit, by the DQCALC procedure \\
\hline SOP & Standard Operating Procedures \\
\hline SPE & solid phase extraction \\
\hline TOF-MS & time of flight-mass spectrometry \\
\hline$\mu \mathrm{g} / \mathrm{L}$ & micrograms per liter \\
\hline$\mu \mathrm{L}$ & microliter \\
\hline$\mu \mathrm{m}$ & micrometer \\
\hline$\mu \mathrm{S} / \mathrm{cm}$ & microsiemens per centimeter \\
\hline USGS & U.S. Geological Survey \\
\hline V & volts \\
\hline VOC & volatile organic compounds \\
\hline WFP & water filtration plants \\
\hline
\end{tabular}





\title{
Methods Used for the Collection and Analysis of Chemical and Biological Data for the Tapwater Exposure Study, United States, 2016-17
}

\author{
By Kristin M. Romanok, ${ }^{1}$ Dana W. Kolpin, ${ }^{1}$ Shannon M. Meppelink, ${ }^{1}$ Maria Argos, ${ }^{2}$ Juliane B. Brown, ${ }^{3}$ \\ Michael J. DeVito, ${ }^{4}$ Julie E. Dietze, ${ }^{1}$ Carrie E. Givens, ${ }^{1}$ James L. Gray, ${ }^{1}$ Christopher P. Higgins, ${ }^{3}$ \\ Michelle L. Hladik, ${ }^{1}$ Luke R. Iwanowicz, ${ }^{1}$ Keith A. Loftin, ${ }^{1}$ R. Blaine McCleskey, ${ }^{1}$ Carrie A. McDonough, ${ }^{4}$ \\ Michael T. Meyer, ${ }^{1}$ Mark J. Strynar, ${ }^{5}$ Christopher P. Weis, ${ }^{4}$ Vickie S. Wilson, ${ }^{3}$ and Paul M. Bradley ${ }^{1}$
}

\section{Abstract}

In 2016, the U.S. Geological Survey (USGS) Environmental Health Mission Area, initiated the Tapwater Exposure Study as part of an infrastructure project to assess human exposure to potential threats from complex mixtures of contaminants. In the pilot phase (2016), samples were collected from 11 States throughout the United States, and in the second phase (2017), the study focused on the Greater Chicago area, including North and South Chicago, Illinois, and East Chicago, Indiana. Residential tapwater samples were collected at private residences during both phases, and during the first phase, samples were collected from Federal office buildings and from one office 19-liter water-bottle source. During the second phase, raw intake and treated (pre-distributional) water samples also were collected from four drinking-water treatment facilities in the Greater Chicago area. Samples were sent to laboratories at the USGS, U.S. Environmental Protection Agency, National Institute of Environmental Health Sciences, and Colorado School of Mines Center for Environmental Risk Assessment, for potential drinking-water pathogens, chemical, and bioassay analyses. These analyses included more than 400 chemicals such as trace elements, steroid hormones, pharmaceuticals, volatile organic compounds, pesticides, per- and polyfluorinated alkyl substances, cyanotoxins, and other organic compounds. The in vitro bioassay analyses included estrogen, androgen, and glucocorticoid receptor activity.

\footnotetext{
${ }^{1}$ U.S. Geological Survey.

${ }^{2}$ University of Illinois.

${ }^{3}$ Colorado School of Mines.

${ }^{4}$ U.S. National Institute of Environmental Health Sciences/National Institutes of Health.

${ }^{5}$ U.S. Environmental Protection Agency.
}

\section{Introduction}

A recent study by the U.S. Geological Survey (USGS) and U.S. Environmental Protection Agency (EPA) was conducted to assess potential ecological exposures to aquatic environments from mixtures of organic compounds present in streams across the country (Bradley and others, 2017). Results of the study indicate a wide range of biologically active organic compounds such as pharmaceuticals, steroid hormones, and pesticides. It should be noted that the organic compounds detected in the Nation's streams were measured at low levels (Bradley and others, 2017). A study was conducted by the EPA (Conley and others, 2017a) in which water-quality samples were analyzed to determine if biological effects from these contaminants were evident in human cells. On the basis of the results of these studies as well as concerns regarding exposures to human health, the USGS, in cooperation with the EPA, National Institutes of Health/National Institute of Environmental Health Sciences (NIH/NIEHS), and Colorado School of Mines (CSM), Center for Environmental Risk Assessment Laboratory, Golden, Colorado (herein referred to as CSM), implemented a pilot Tapwater Exposure Study to determine whether these biologically active organic compounds were detected in drinking water. Although municipalities treat and monitor public water supplies, private water supplies are not monitored in the same way. Additionally, monitoring from State and local government stops at the curb, and potential sources of contaminants may be from indoor plumbing. The Tapwater Exposure Study is designed to study the exposure potential to homeowners from drinking water at the point of use.

During the pilot phase of the Tapwater Exposure Study (2016), referred to as Phase I, 11 paired (residential and workplace) drinking-water sources were sampled in 11 States, for a total of 26 sampling sites. Samples were analyzed for more than 400 inorganic and organic compounds. These compounds included trace elements, pharmaceuticals, pesticides, steroid 
hormones and related compounds, per- and polyfluoroalkyl substances (PFASs), and volatile organic compounds (VOCs). This combination of workplace and residential sources of tapwater (including self-supply and public sources) encompasses multiple exposure pathways.

During the second year of the study (2017), referred to as Phase II, the USGS, EPA, NIEHS, and CSM collaborated with the University of Illinois at Chicago and other nongovernmental agencies to increase the number of sampling locations and participants. Phase II participants included 45 residential sampling locations and 4 water filtration plants (WFPs) in Chicago, Illinois, and East Chicago, Indiana. Samples from the WFPs were collected from the raw-water intake at Lake Michigan and from a treated-water source within the facility prior to distribution.

\section{Purpose and Scope}

This report describes the sampling site selection and sampling and analytical methods used for Phases I and II of the USGS Environmental Health Mission Area, Tapwater Exposure Study. Phase I of the study was conducted in 2016, in 11 States throughout the United States, and Phase II was conducted in 2017 and was focused solely on neighborhoods in Chicago, Illinois, and East Chicago, Indiana. Phase II was planned and implemented in cooperation with the University of Illinois at Chicago and other nongovernmental agencies. The study was designed to capture a "snap shot" of potential contaminants to which an individual may be exposed in tapwater and to gain a better understanding of the chemical or biological exposures an individual encounters on a daily basis. Therefore "first-flush" protocols were not utilized.

\section{Methods}

The description of the sampling site selection, sampling protocols, and analytical methods are provided below.

\section{Sampling Site Selection}

Sampling sites were selected for Phase I by volunteer USGS employees to ensure national distribution and a cross section of public/self-supply and paired home/workplace settings. Twenty-six samples were collected in 11 States (table 1) between May and September 2016. These samples were collected from both public and self-supply sources, which included treated and untreated groundwater and surface water and commercial sources (primary source unknown).

Sampling sites for Phase II (2017) were selected in conjunction with the University of Illinois at Chicago and nongovernmental agencies in Chicago, Illinois, and East Chicago, Indiana. Residential samples were collected from 15 sites in East Chicago, Indiana, on August 28 and 30, and September 11, 2017 (table 1). Four additional samples and one quality-assurance sample were collected twice from two City of East Chicago WFPs on August 29 and September 12, 2017. Samples collected at the two City of East Chicago WFPs include water from a raw-water intake and a source of treated water prior to distribution. In Chicago, Illinois, 30 samples were collected from residential taps on November 27 and 28, and December 4-6, 2017. Raw and treated water-quality samples (along with quality-assurance samples) were also collected twice at two City of Chicago WFPs on July 19, 2017, and November 29, 2017. Source water for both of the WFP sampling sites is from Lake Michigan.

Residential tapwater station names and identification numbers are anonymized. Latitude and longitude location data are generalized and do not indicate exact sample site location for security and protection of personally identifiable information.

\section{Sampling Methods}

Sampling methods followed basic guidelines in the USGS National Field Manual (U.S. Geological Survey, variously dated) regarding sample cleanliness, bottle labeling and handling, and sample preservation. For Phase I, detailed sampling Standard Operating Procedures (SOPs), which were developed on the basis of protocols outlined in the USGS National Field Manual and which described proper sample-handling procedures, bottle filling order, and analytical method requirements, were provided to the project personnel collecting the samples. Those conducting the sampling were instructed to don clean, nitrile gloves prior to creating a clean workspace on adjacent counter tops. The instructions included prompts to indicate when donning a new set of clean gloves and laying out new, clean workspace covers was necessary. Samples were collected from the kitchen tap into appropriately cleaned and (or) rinsed bottles, according to the SOPs that were provided. Kitchen taps were not prepared or cleaned prior to sampling, because the purpose of the study was to determine "normal, everyday exposure" for an individual. Bottles used in sample collection for PFAS analyses in Phase I were prewashed by sampling personnel prior to sample collection (first with soap and water, followed by tapwater, then three deionized water rinses, and finished with a methanol rinse before being air dried and bagged). Subsequent analyses (Phase II) for PFAS samples were performed at multiple laboratories and each laboratory provided pre-cleaned sample containers. Bottle filling began immediately after the tap was turned on; care was taken to ensure the bottles did not come in contact with the surface of the tap. For samples collected from treated-water sources (public water supplies), ascorbic acid was added to the VOC and pharmaceutical sample collection bottles to neutralize the effects of chorine or chloramine that may have been introduced during the drinking-water disinfection process. All samples were filtered and preserved when required, placed into two self-closing plastic bags, placed on ice in a cooler lined with plastic bags, and shipped overnight to participating 
laboratories. Additional filtering may have been performed at the laboratories, depending on the analytical method requirements. Measured qualities of water, collectively referred to as field parameters, include temperature, measured in degrees Celsius $\left({ }^{\circ} \mathrm{C}\right)$; dissolved oxygen, measured in milligrams per liter $(\mathrm{mg} / \mathrm{L})$; specific conductance, measured in microsiemens per centimeter $(\mu \mathrm{S} / \mathrm{cm})$; and the potential of hydrogen $(\mathrm{pH})$, measured in units of moles per liter of hydrogen ions. These field parameters were measured one time at each sampling site, following bottle filling, using a multiparameter instrument. Measurements were taken from an open container with the water flowing. Total sample collection time, including the measurements of field parameters, was approximately 20 to 30 minutes. Notes were taken as to whether samples were collected directly from the tap or from a point-of-use filtration system (table 1). For the sample collected from the commercial 19-liter water-bottle source, the water cooler nozzle was only activated during bottle filling and was not allowed to run the entire sampling period.

For Phase II, updated protocols were provided to sampling personnel with adjustments made on the basis of experience gained from Phase I sampling. Although the sampling methods remained the same with regard to sampling cleanliness, bottle labeling and handling, and preservation, some analytical methods were deleted or added, and those adjustments are outlined in the Analytical Methods section. As in Phase I, samples were collected either directly from the tap or from a point-of-use filtration system and were noted (table 1). No information was collected pertaining to materials in residential plumbing or service lines providing water to the residence taps. Samples from raw intake water at WFPs were collected using a dipper water-sampling device provided by the facility, and sample bottles were handled and filled as instructed in SOPs. Treated (pre-distribution) water samples at the WFPs were collected from a tap, using the same procedures as for residential samples.

\section{Analytical Methods}

Water-quality chemical and bioassay samples collected during Phases I and II were sent to USGS, EPA, NIEHS, and CSM laboratories for analyses. Microbiological samples were collected and sent to the USGS Michigan Water Science Center Bacteriological Research Laboratory in Lansing, Michigan.

\section{Chemical Analyses}

Water-quality samples collected during Phases I and II were sent to the USGS National Water Quality Laboratory (NWQL) in Denver, Colorado; the USGS Organic Geochemistry Research Laboratory (OGRL) in Lawrence, Kansas; the USGS Organic Chemistry Research Laboratory (OCRL) in Sacramento, California; the EPA National Exposure Research Laboratory (NERL) in Research Triangle Park, North Carolina; the EPA National Health and Environmental
Effects Laboratory (NHEEL) in Research Triangle Park, North Carolina; the NIEHS National Toxicology Program (NTP) Laboratory in Research Triangle Park, North Carolina; and the CSM Laboratory in Golden, Colorado. Modifications for Phase II required the discontinuation of certain analytical methods and the addition of others, requiring that additional samples be sent to the NWQL and the USGS Redox Chemistry Laboratory (RCL) in Boulder, Colorado. These changes are outlined below, and a complete list of analytical laboratories, methods, and compounds are provided in table 2. Definitions of, and procedures used to determine reporting levels for participating laboratories can be found in NWQL Technical Memorandum 15.02 (U.S. Geological Survey, 2015) and Armbruster and Pry (2008).

\section{National Water Quality Laboratory (NWQL), Denver, Colorado}

The NWQL analyzed water-quality samples for steroid hormones and related compounds; human-use pharmaceuticals, pharmaceutical metabolites, and selected polar organic compounds; heat and ambient purgeable VOCs; selected trace elements and nitrate plus nitrite; and PFASs.

\section{Steroid Hormones and Related Compounds (Phase I only)}

Unfiltered samples were analyzed for 20 steroid hormone and related compounds, including natural and synthetic estrogen and androgen compounds, natural and synthetic progestin compounds, sterols, and Bisphenol A (table 2). Samples were collected in 500-milliliter (mL), clear, high-density polyethylene (HDPE) bottles. Concentrations were determined using solid phase extraction (SPE) and gas chromatography/tandem mass spectrometry (GC/MS-MS) (Foreman and others, 2012). Concentrations are reported in nanograms per liter (ng/L). Results are reported using the interim reporting levels (IRL) and minimum reporting levels (MRL) methods. The following isotope dilution standards were used as part of the internal laboratory quality assurance and quality control $(\mathrm{QA} / \mathrm{QC})$ : 16-Epiestriol-2,4-d2; 17-alpha-Ethynylestradiol-2,4,16,16d4; 17-beta-Estradiol-13,14,15,16,17,18-13C6; Bisphenol F-d10; Bisphenol-A-d16; Cholesterol-d7; cis-Androsterone2,2,3,4,4-d5; Estriol-2,4,16,17-d4; Estrone-13,14,15,16,17,1813C6; Medroxyprogesterone-d3; Mestranol-2,4,16,16-d4; tt-16,16,17-d3; Progesterone-2,3,4-13C3; and trans-Diethyl1,1,1',1'-d4-stilbesterol-3,3',5,5'-d4. Results for these surrogate standards are reported in percent.

\section{Human-Use Pharmaceuticals, Pharmaceutical Metabolites, and Selected Polar Organic Compounds (Phases I and II)}

Filtered samples were analyzed for 113 human-use pharmaceuticals, pharmaceutical metabolites, and selected polar organic compounds (table 2). Samples were collected in 20-mL, amber, glass vials and were filtered in the field 
using a 25-millimeter $(\mathrm{mm}), 0.7$-micrometer $(\mu \mathrm{m})$, glass fiber, syringe-tip filter. Samples were analyzed using direct injection high-performance liquid chromatography/tandem mass spectrometry (HPLC/MS-MS), operated in positive ion mode (Furlong and others, 2014). Concentrations are reported in nanograms per liter. Results are reported using the RLDQC method (reporting limit by the DQCALC procedure; U.S. Geological Survey, 2015). The following isotope dilution standards were used as part of the internal laboratory QA/QC: Amitriptyline-d3, Carisoprodol-d7, Erythromycin-13C-d3, Ezetimibe-d4, Fenofibrate-d6, Fexofenadine-d10, Fluvoxamine-d4, Hydrocortisone-13C3, Ketoconazole-d4, Loperamide-d6, Loratadine-d4, Lorazepam-d4, N-Desmethyldiltiazem-d4, Oxazepam-d5, Promethazine-d6, Propoxyphene-d11, Raloxifene-d10, Ranitidine-d6, Tamoxifen-d5, Tiotropium-d3, and Verapamil-d6. Results for these surrogate standards are reported in percent.

\section{Heat Purgeable Volatile Organic Compounds (Phase II only)}

Samples were analyzed for 37 VOCs, using the heat purgeable method outlined in Rose and others (2016) (table 2). Samples were collected in three, $40-\mathrm{mL}$, glass, amber vials, which contained ascorbic acid when samples were taken from a treated water source, then preserved with hydrochloric acid and placed on ice. Helium was used to purge the sample of VOCs in order to trap them in an appropriate tube for analysis. For the heat purgeable method, samples were heated to $60{ }^{\circ} \mathrm{C}$, then VOCs were purged from water samples by using helium. Results were determined using gas chromatography/ mass spectrometry (GS/MS), with full scan/selected ion monitoring. Concentrations are reported in micrograms per liter $(\mu \mathrm{g} / \mathrm{L})$. The reporting level procedure used for this method is RLDQC and MRL (table 2). The following isotope dilution standards were used as part of the internal laboratory QA/QC: 1,2-Dichloroethane-d4; 1-Bromo-4-fluorobenzene; Isobutyl alcohol-d6; Tetrahydrofuran-d8; and Toluene-d8. Results for these surrogate standards are reported in percent.

\section{Ambient Purgeable Volatile Organic Compounds (Phases I and II)}

Whole-water samples were analyzed for 49 ambient purgeable VOCs by using gas chromatography (table 2). Samples were collected in three, $40-\mathrm{mL}$, glass, amber vials, which contained ascorbic acid when samples were taken from a treated water source, then preserved with hydrochloric acid and placed on ice. In brief, helium was used to remove VOCs from water samples at ambient temperature. The purged VOCs were trapped in a tube, desorbed, and prepared for analysis by GC/MS (Rose and others, 2016). Concentrations are reported in micrograms per liter. The reporting level procedure used for this method is RLDQC and MRL (table 2). The following isotope dilution standards were used as part of the internal laboratory QA/QC: 1-Bromo-3-chloropropane-d6,
1-Bromo-4-fluorobenzene, and Toluene-d8. Results for these surrogate standards are reported in percent.

\section{Selected Trace Elements (Phases I and II) and Nitrate plus Nitrite (Phase II only)}

Whole-water samples were analyzed for 19 trace elements (table 2). The methods are described in Hoffman and others (1996) and Fishman and Friedman (1989). Samples were collected in 250-mL, acid-rinsed HDPE bottles and acidified with ultra-pure nitric acid. At the laboratory, samples were digested with hydrochloric acid, heated, and analyzed by inductively coupled plasma-mass spectrometry (ICP-MS) or by atomic absorption (cadmium and calcium) as described in Fishman and Friedman (1989) and Hoffman and others (1996). The reporting level type used by the NWQL varies by analyte (table 2). The reporting level type used to report lead concentrations is DLBLK, meaning the detection level is determined using blank data.

Nitrate plus nitrite was analyzed using methods described in Patton and Kryskalla (2011). Samples were collected in a $10-\mathrm{mL}$ vacuum tube and immediately placed on ice. Briefly, results of filtered water-quality samples were analyzed for nitrate plus nitrite using enzymatic reduction and colorimetric determinative methods. Concentrations are reported in milligrams per liter. Results are reported using the DLDQC procedure (detection limit by the DQCALC procedure; U.S. Geological Survey, 2015).

\section{Per- and Polyfluroalkyl Substances (PFAS, Phases I and II)}

Samples were analyzed for 11 perfluorocarboxylic acids and 5 perfluorosulfonic acids by direct aqueous injection, liquid chromatography/tandem mass spectrometry (DAI-LC/ MS-MS) (table 2). Subsamples (30 mL each) were taken from PFAS samples analyzed by the CSM and stored in high-density polyethylene bottles at $-4{ }^{\circ} \mathrm{C}$ prior to analysis. An 850-microliter $(\mu \mathrm{L})$ aliquot of each raw, unfiltered sample was transferred to a polypropylene liquid chromatograph vial, amended with eight stable-isotope labeled internal standards (IS), and brought to a final volume of $950 \mu \mathrm{L}$ with methanol. Standards were prepared with corresponding amounts of IS and methanol. Samples were analyzed by injecting $20 \mu \mathrm{L}$ to a triple-quadrupole LC/MS-MS system modified to minimize background PFAS contamination, separating with a methanol/ water/ammonium acetate gradient on a reversed-phase porous shell column, and monitoring at least two distinct precursorproduct transition ions for quantitation and confirmation. Calibration and quantitation were conducted using isotope-dilution quantification over a range of 1 to $1,000 \mathrm{ng} / \mathrm{L}$.

\section{USGS Organic Geochemistry Research Laboratory (OGRL), Lawrence, Kansas}

The OGRL analyzed water-quality samples for glyphosate, glufosinate, and aminomethylphosphonic acid; steroid 
hormones and phytoestrogens; acetamide herbicides and degradation products; selected antibiotics; and cyanotoxins. Samples for glyphosate, glufosinate, and aminomethylphosphonic acid; steroid hormones, hormone conjugates, and phytoestrogens; acetamide herbicides and degradation products; and selected antibiotics analyses were collected in $1,000-\mathrm{mL}$, glass, amber, baked bottles and immediately placed on ice. The reporting level procedure used by the OGRL is Limit of Quantitation (LOQ) for all methods.

\section{Glyphosate, Glufosinate, and Aminomethylphosphonic acid (Phase I only)}

Samples were analyzed for glyphosate, glufosinate, and aminomethylphosphonic acid (table 2). Samples were filtered at the laboratory upon receipt. Samples were extracted onto SPE cartridges, and the SPE cartridges were rinsed with $500 \mu \mathrm{L}$ of deionized water. All sample extracts were analyzed by LC/MS-MS with electrospray ionization (ESI) in negativeion mode using multiple reaction monitoring (Meyer and others, 2009). Concentrations are reported in micrograms per liter.

\section{Steroid Hormones, Hormone Conjugates, and Phytoestrogens (Phases I and II)}

Samples were analyzed for 57 steroid hormones, hormone conjugates, progestins, mycotoxins, androgens, and phytoestrogens (table 2). The method is described in Yost and others (2014) and briefly described here. The method was modified to include the analyses of progestins and mycotoxins (table 2). Samples were filtered in the laboratory upon receipt, processed with SPE using 200 milligrams (mg) hydrophilic lipophilic balanced (HLB) cartridges (Waters Corp., Milford, Massachusetts), eluted with methanol, and analyzed using ultra-pure LC/MS-MS. Concentrations are reported in nanograms per liter.

\section{Acetamide Herbicides and Degradation Products (Phases I and II)}

Samples for 33 acetamide herbicides and associated degradates were analyzed using an online SPE LC/MS-MS with ESI and positive- and negative-ion switching modified from the USGS-approved method of Lee and Strahan (2003) (table 2). Samples were filtered upon receipt at the laboratory. Concentrations are reported in micrograms per liter.

\section{Selected Antibiotics (Phases I and II)}

Samples were analyzed for five groups of antibiotic compounds (fluoroquinolines, macrolides, sulfonamides, tetracyclines, and pharmaceuticals [carbamazepine and ibuprofen]) plus chloramphenicol, lincomycin, ormetoprim, and trimethoprim (table 2). Samples were analyzed using a method modified from Meyer and others (2007). Samples were filtered in the laboratory upon receipt. Samples were extracted using SPE, and concentrations were determined using ultra-pressure LC/MS-MS with ESI using multiple reaction monitoring.
Except for chloramphenicol and ibuprofen, samples were analyzed in positive-ion mode (USGS OGRL, written commun., 2014). Concentrations are reported in micrograms per liter.

\section{Cyanotoxin Screening (Phase II only)}

Screening for cyanotoxins (cylindrospermopsins, microcystins, saxitoxins, and domoic acid) was performed using the enzyme-linked immunosorbent assays (ELISA) (table 2). A description of the samples screened for cyanotoxins and the ELISA method can be found in Loftin and others (2016) and Graham and others (2010). Samples were collected in two $40-\mathrm{mL}$, glass vials or two $125-\mathrm{mL}$, sterile, polyethylene terephthalate glycol (PETG) bottles and shipped on ice to the analyzing laboratory. Samples were treated in the field with either ascorbic acid (samples collected on July 19, 2017, were also collected in replicate with no treatment) or sodium thiosulfate. Concentrations are reported in micrograms per liter.

\section{USGS Organic Chemistry Research Laboratory (OCRL), Sacramento, California}

The OCRL analyzed water-quality samples for currentuse pesticides and pesticide degradates, diuron and diuron degradates and neonicotinoid insecticides, and disinfection by-products. The methods are briefly summarized below. During Phase I, samples were collected in three, 1,000-mL, amber, glass, baked bottles and placed on ice; for Phase II, samples were collected in one, 1,000-mL, amber, glass, baked bottle and placed on ice.

\section{Pesticides and Pesticide Degradates (Phases I and II)}

Filtered samples were analyzed for 60 pesticides and pesticide degradates (table 2). Samples were spiked as required, extracted using SPE, dried, and then eluted with ethyl acetate. Finally, samples were reduced to $200 \mu \mathrm{L}$, and an internal standard was added. Concentrations were determined using GC/MS and are described in Hladik and others (2008; additional compounds were added to the method post-publication and are noted in table 2 of the current report). Concentrations are reported in nanograms per liter. The following isotope dilution standards were used as part of the internal laboratory QA/QC: 13C Atrazine, 13C Fipronil, and d-Trifluralin. Results for these surrogate standards are reported in percent.

\section{Diuron and Diuron Degradates and Neonicotinoid Insecticides (Phases I and II)}

Filtered samples were analyzed for the herbicide diuron and three diuron degradates and six neonicotinoid insecticides (table 2). Samples were spiked with surrogate standards monuron (Chem Service, West Chester, Pennsylvania) and (or) imidacloprid- $d_{4}$ (Cambridge Isotope Laboratories, Andover, Massachusetts). The samples were then extracted using SPE, dried, and eluted with dichloromethane (DCM) and acetone. Finally, the elution was dried to less than $0.2 \mathrm{~mL}$, and an IS 
$\left({ }^{13} \mathrm{C}_{3}\right.$-caffeine) was added. Extracted samples were analyzed using LC/MS-MS (Hladik and Calhoun, 2012; additional compounds were added to the method post-publication and are noted in table 2 of the current report). Concentrations are reported in nanograms per liter. The following isotope dilution standards were used as part of the internal laboratory QA/QC: Imidacloprid-d4 and monuron. Results for these surrogate standards are reported in percent.

\section{Disinfection By-Products (Phase I only)}

Filtered samples were analyzed for 28 disinfection byproducts (table 2). Samples were spiked with surrogate standards 1-bromo-4-fluorobenzene and 1,2-dichlorobenzene-d4 and extracted using SPE within 48 hours. Extracts were then dried and eluted with $10 \mathrm{~mL}$ of methyl tert-butyl ether and reduced to $400 \mu \mathrm{L}$. Finally, 1-chlorooctane internal standard was added. Extracts were analyzed using GC/MS (Hladik and others, 2014). Concentrations are reported in nanograms per liter. The following isotope dilution standards were used as part of the internal laboratory QA/QC: 1-bromo-4-fluorobenzene and 1,2-dichlorobenzene-d4. Results for these surrogate standards are reported in percent.

\section{USGS Redox Chemistry Laboratory (RCL), Boulder, Colorado (Phase II only)}

Hexavalent chromium and total chromium, along with a suite of cations, anions, and trace elements, were analyzed at the RCL (table 2). Samples were collected in two 2-mL centrifuge tubes for each analysis. Hexavalent chromium was separated from trivalent chromium in the field, using a disposable cation-exchange cartridge and syringe/filter assemblage and preserved with hydrochloric acid (Ball and McCleskey, 2003). These speciated samples were later analyzed at the laboratory, using cation exchange with a Zeeman-corrected graphite furnace atomic absorption spectrometry (GFAAS) method as described in Ball and McCleskey, 2003.

Whole-water samples were analyzed for 32 trace elements and alkalinity. Samples were collected in a $125-\mathrm{mL}$, HDPE bottle and placed on ice. Cations and trace elements were analyzed using inductively coupled plasma-optical emissions spectrometry (ICP-OES), anions were analyzed using ion chromatography, and alkalinity was analyzed using an automated titration, with first derivative near $\mathrm{pH} 4.5$ (Pfaff, 1993; EPA, 2014). Trace element cations and anions are reported in milligrams per liter, and alkalinity in milligrams per liter of bicarbonate. Lead concentrations were also analyzed by GFAAS and results are reported in micrograms per liter (Hergenreder, 2011). This method reports data based on Method Detection Levels.

\section{EPA National Exposure Research Laboratory (NERL; Phases I and II)}

Samples for per- and polyfluoroalkyl substances (PFASs) were collected in three $15-\mathrm{mL}$ Falcon tubes and frozen during Phase I and in one $500-\mathrm{mL}$ polyethylene bottle (with ascorbic acid added for treated water samples) in Phase II and placed on ice. Samples were analyzed using an SPE specially prepared for the retention of these compounds. After samples were eluted, concentrated, and buffered as described in the analytical SOPs, analyses were performed using ultra-high performance liquid chromatography-tandem mass spectrometry, operated in ESI (EPA, 2017). Concentrations are reported in nanograms per liter (table 2).

\section{Colorado School of Mines (Phases I and II)}

During Phase I, aliquots (approximately $7 \mathrm{~mL}$ ) from 1-liter (L) tapwater samples were transferred to new, preweighed 15-mL polypropylene Falcon tubes for PFAS analysis. All remaining sample preparation was done within the vessel. The weight of the tube was recorded after sample collection to measure subsample volume gravimetrically. During Phase II, samples were collected directly into triplicate $15-\mathrm{mL}$ polypropylene Falcon tubes. Each sample was diluted so that the water sample made up 64 percent of the total volume, with 23 percent Optima HPLC-grade methanol (Fisher Scientific), 3 percent of 0.01 percent Optima HPLC-grade ammonium hydroxide (Fisher Scientific, Fair Lawn, New Jersey) in Optima HPLC-grade water (Fisher Scientific), and 10 percent Optima HPLC-grade isopropanol (Fisher Scientific). Internal standards (labeled PFASs in methanol and isopropanol; appendix 1) were spiked directly into the vessel at $74 \mathrm{ng} / \mathrm{L}$. Each sample was then homogenized by vortexing for 15-20 seconds and centrifuged at 4,000 revolutions per minute (rpm) for 10 minutes. A $1.35-\mathrm{mL}$ aliquot was transferred to a $2-\mathrm{mL}$ autosampler vial for analysis. Samples were kept refrigerated until analysis.

Laboratory method blanks (IS added) and method double blanks (no internal standard added) followed the same procedure used for the tapwater samples and were processed in vials, in new pre-weighed 15 -mL polypropylene Falcon tubes. An additional set of double blanks prepared directly in autosampler vials were included in the analysis to check for instrumental contamination. Quality control samples were also prepared directly in autosampler vials. The QC samples consisted of 300 picograms (pg) of all target analytes and $100 \mathrm{pg}$ of all internal standards brought to $1.35 \mathrm{~mL}$ with the same solvent mix as samples and blanks. Blanks, double blanks, and QC samples in HPLC vials were kept refrigerated until analysis. 
The 7-mL in-vessel sample preparation method was demonstrated to achieve recoveries \pm 30 percent of known concentrations (mean range 75-113 percent) for all targeted PFASs except perfluoro-n-octadecanoic acid (PFODA; $34 \pm 14$ percent) and 10:2 FTS (fluorotelomer sulfonate, $133 \pm 5$ percent) via a spike recovery test in which six replicate 7-mL samples of HPLC-grade water were spiked with the target analytes and carried through the protocol (appendix 2). Perfluoro-n-octadecanoic acid and perfluorobutyrate acid (PFBA) were not included in the final analyte list for water samples analyzed in this study because of recovery issues and chromatographic issues, respectively.

\section{High-Performance Liquid Chromatography}

A 1-mL aliquot of each water sample was injected on a SCIEX ExionLC HPLC system using a Gemini C18 analytical column $(3 \mathrm{~mm} \times 100 \mathrm{~mm} \times 5 \mu \mathrm{m}$; Phenomenex, Torrance, California) preceded by one SecurityGuard C18 Guard Cartridge ( $4 \mathrm{~mm} \times 2 \mathrm{~mm}$ I.D.; Phenomenex) and two Zorbax DIOL guard columns $(4.6 \mathrm{~mm} \times 12.5 \mathrm{~mm} \times 6 \mu \mathrm{m}$; Agilent, Santa Clara, California). The column oven was held at $40{ }^{\circ} \mathrm{C}$. The aqueous mobile phase (A) was 20 millimolar ammonium acetate (Fisher Scientific) in Optima HPLC-grade water, and the organic mobile phase (B) was 100 percent Optima HPLCgrade methanol. Eluent flow rate was held at 0.60 milliliters per minute $(\mathrm{mL} / \mathrm{min})$. Eluent composition was ramped from 90 percent $A$ to 50 percent A over the first 0.5 minutes, then to 1.0 percent $A$ at 8 minutes and held until 13 minutes, then ramped to 90 percent $A$ at 13.5 minutes and held to 20 minutes.

\section{Quadrapole Time of Flight-Mass Spectrometry (OTOF-MS)}

Per- and polyfluoroalkyl substances were measured on a SCIEX X500R QTOF-MS system (Framingham, Massachusetts), using ESI in negative mode with SWATH Data-Independent Acquisition for both time of flight-mass spectrometry (TOF-MS) and MS-MS modes. Precursor ion data were collected for $\mathrm{m} / \mathrm{z}$ (ratio of an ion's mass number in atomic mass units to its charge number) $100-1,200$ for 1,283 cycles with a total scan time of 842 milliseconds (ms) and accumulation time of $20 \mathrm{~ms}$, with ion spray voltage set at $-4,500$ volts $(\mathrm{V})$ and temperature set to $550{ }^{\circ} \mathrm{C}$. The ion source, curtain, and collision (CAD) gas were set to 60 pounds per square inch (psi), $35 \mathrm{psi}$, and $10 \mathrm{psi}$, respectively. The collision energy was set to $-5 \mathrm{~V}$ and the declustering potential to $-20 \mathrm{~V}$, both with no spread. Product ion (MS-MS) scanning was conducted for m/z 50-1,200 Dalton (Da). The accumulation time for each SWATH window was $50 \mathrm{~ms}$, and collision energy was $-35 \mathrm{~V}$ with $30 \mathrm{~V}$ spread. The instrument was mass calibrated every five injections using SCIEX ESI Negative Calibration Solution.

\section{Data Acquisition Parameters}

\section{Quantitative Analysis}

A list of target analytes and IS used for quantitation is provided in appendix 1. All labeled and unlabeled analytical standards were purchased from Wellington Laboratories (Guelph, Ontario). Concentrations of target analytes were corrected for internal standard recovery.

Data acquisition and processing were done using SCIEX OS Version 1.2 to quantify targeted analytes. Initial integration parameters included defining 90 percent of lowest-intensity peaks as noise and using a baseline-subtract window of 2 minutes, a minimum peak intensity of 100 , and a peak width of 3 points. Some peaks with peak intensity below the threshold were manually integrated where retention time, accurate mass, and isotope confidence were determined to be satisfactory. The confirmation of targeted analytes was based on retention time and accurate mass (extracted-ion chromatogram (XIC) window $0.00131 \mathrm{Da}$ ) compared to analytical standards. Generally, mass error was less than 5 parts per million (ppm), although a few peaks displayed mass errors less than $20 \mathrm{ppm}$. In five cases, the lowest point of the calibration curve did not meet these specifications and had a mass error greater than 20 ppm [2-perfluorohexyl ethanoic acid [6:2] [6:2 FTA, fluorotelomer acid], perfluoro-n-dodecanoic acid [PFDoA], perfluoro-n-tetradecanoic acid [PFTeDA], 3-perfluoropentyl propanoic acid [5:3] [5:3 FTA], 3-perfluoroheptyl propanoic acid [7:3] [7:3 FTA]), but the calibration points were considered acceptable based on accuracy (to predicted concentration), peak definition, and retention time.

Calibration range, limit of quantitation, and linear fit $\left(\mathrm{r}^{2}\right)$ of the calibration curves for all analytes are shown in appendix 3. Calibration curve fit was calculated on the basis of linear regression (using $1 / \mathrm{x}$ or $1 / \mathrm{x}^{2}$ weighting), and linearity ranged from $\mathrm{r}^{2}$ of 0.974 to 0.999 (minimum acceptable $\mathrm{r}^{2}=0.97$ ). Lower and upper LOQs were determined as the lowest and highest calibration standards calculated to be within 30 percent of the expected value, respectively. The lower LOQ typically ranged from 0.58 to $5.8 \mathrm{ng} / \mathrm{L}$, with the exception of selected analytes, which ranged from less than $12 \mathrm{ng} / \mathrm{L}$ (N-methylperfluoro-1-octanesulfonamide [Me-FOSA] and N-ethylperfluoro-1-octanesulfonamide [Et-FOSA], 6:2 FTA, perfluoro-n-pentanoic acid [PFPeA], and 3-perfluoropropyl propanoic acid [3:3] [3:3 FTA]) to $23 \mathrm{ng} / \mathrm{L}$ (Perfluoro-1-octanesulfonamide [FOSA], 2-perfluorodecyl ethanoic acid [10:2] [10:2 FTA], perfluoro-n-heptanoic acid [PFHpA], PFODA, and perfluoro-1-pentanesulfonate [PFPeS]). The upper LOQs typically ranged from 1,161 to $2,323 \mathrm{ng} / \mathrm{L}$, with the exception of selected analytes, which could not be reliably quantified above $232 \mathrm{ng} / \mathrm{L}$ (C13, C16, and C18 carboxylic acids, 7:3 FTA, the FOSA 
and perfluoro-1-octanesulfonamidoacetic acid [FOSAA], 2H-perfluoro-2-dodecenoic acid [10:2] [10:2 FTUA], 1H,1H,2H,2H-perfluorohexane sulfonate [10:2] [10:2 FTS], perfluoro-1-heptanesulfonate [PFHpS], and perfluoro1-dodecanesulfonate [PFDoS]).

A QC sample was analyzed after every 10 samples to ensure all compounds remained within \pm 30 percent of known concentrations (that is, to monitor for instrumental drift). Accuracies ranged from 76 to 141 percent. All but one analyte (10:2 FTS) was quantified within \pm 30 percent.

Laboratory blanks, both experimental (blanks and double blanks prepared in 15-mL polypropylene Falcon tubes) and analytical (double blanks prepared in autosampler vials) were included to monitor for possible contamination throughout the sample pre-processing (after collection) and analytical processing. Three analytes (FOSA, Me-FOSA, and Et-FOSA) indicated low levels of contamination in one or more laboratory method blank. The lower LOQs were adjusted to be three times the highest concentration in the blanks and were applied to quantify these analytes. No contamination was identified in any of the double blanks.

\section{Microbiological Analyses (Phases I and II)}

Samples for microbiological analyses were collected in two 2.5-L PETG bottles and preserved with sodium thiosulfate, then placed on ice. Samples were collected and sent to the USGS Michigan Water Science Center Bacteriological Research Laboratory in Lansing, Michigan, for analyses. Further information regarding these methods can be found at https://mi.water.usgs.gov/projects/MBindex.html (accessed April 26, 2018).

\section{Bioassay Analyses (Phases I and II)}

Bioassay analyses were performed at the USGS National Fish Health Research Laboratory (NFHRL), Kearneysville, West Virginia; the NIEHS NTP Laboratory, Research Triangle Park, North Carolina; and the EPA NHEEL, Research Triangle Park, North Carolina. Samples for these assays were extracted at the OGRL in Lawrence, Kansas, and shipped on ice to the analyzing laboratories. Samples for these bioassays were collected in four $1,000-\mathrm{mL}$, amber, glass, baked bottles and placed on ice.

\section{Extraction Method (Phases I and II)}

Each sample was collected in four (A,B,C,D) 1-L, prebaked, narrow-mouth bottles. The samples were shipped on ice at 2 to $4{ }^{\circ} \mathrm{C}$ to the OGRL. All water samples were logged in and filtered through a 0.7-nominal pore-size glass-fiber filter upon arrival at OGRL and refrigerated at 2 to $4{ }^{\circ} \mathrm{C}$ in the dark until processing, which occurred within 36 hours of arrival at OGRL. Each 1-L sample bottle was weighed with the cap on prior to extraction. Waters Corporation (Milford,
Massachusetts) 200-mg, 6-mL, hydrophilic-lipophilic balanced SPE cartridges were prepared by rinsing with $8 \mathrm{~mL}$ of methanol followed by $8 \mathrm{~mL}$ of Type 1 water generated by an Elga Purelab Ultra water purifier. Each 1-L sample was passed through an HLB cartridge at approximately $10 \mathrm{~mL} / \mathrm{min}$, using a Supelco (St. Louis, Missouri) 24-port vacuum extraction rack. The bottle was rinsed with $8 \mathrm{~mL}$ of Type 1 water and passed through the cartridge. After extraction, SPE cartridges were dried by keeping them under a vacuum for an additional 20 minutes. The sample bottles with the cap were reweighed, and the volume of extracted sample was calculated. Each SPE cartridge was transferred to a 24-port vacuum rack with disposable Teflon liners to prevent cross contamination and then was eluted with two 4-mL aliquots of methanol into $15-\mathrm{mL}$, glass conical bottom test tubes. The sample eluates were placed into a Zymark (Hopkinton, Massachusetts) nitrogen evaporator at $40^{\circ} \mathrm{C}$. The $\mathrm{A}, \mathrm{B}, \mathrm{C}$, and $\mathrm{D}$ aliquots were then evaporated to approximately $1 \mathrm{~mL}$, and the $\mathrm{B}, \mathrm{C}$, and $\mathrm{D}$, aliquots were combined with $\mathrm{A}$. In addition, the $\mathrm{B}, \mathrm{C}$, and $\mathrm{D}$ test tubes were rinsed with two 1-mL aliquots of methanol, which were subsequently transferred into A to ensure quantitative transfer of the samples. The combined sample aliquot was evaporated to approximately $1 \mathrm{~mL}$ to which $10-\mu \mathrm{L}$ of Type 1 water was added. The combined aliquot was evaporated to approximately $10-\mu \mathrm{L}$ to which methanol was added to bring the final volume to $400 \mu \mathrm{L}$; then $100-\mu \mathrm{L}$ aliquots were pipetted into four $2-\mathrm{mL}$, crimp-top vials with $100-\mu \mathrm{L}$ glass inserts and Teflon-lined crimp tops and stored in a freezer at negative $18^{\circ} \mathrm{C}$ for archival or until shipment to the NFHRL and EPA laboratories for bioassay analysis.

\section{USGS National Fish Health Research Laboratory (NFHRL)}

The Bioluminescent Yeast Estrogen Screen (BLYES) and Bioluminescent Yeast Androgen Screen (BLYAS) were performed to assess the net estrogenic or androgenic activity of water sample extracts (Sanseverino and others, 2005, 2009). Water, which was previously shipped and extracted at the OGRL, was then shipped on ice to the NFHRL where it was stored at negative $20^{\circ} \mathrm{C}$ upon receipt. Samples were prepared using methanol. The assay was run using a protocol adapted from Ciparis and others (2012). Briefly, $10 \mu \mathrm{L}$ of sample extract was added in triplicate to the wells of a white, solidbottom 96-well plate and evaporated at room temperature in a Class II biological safety cabinet. After the solvent was evaporated, $200 \mu \mathrm{L}$ of a 48 -hour culture of strain BLYES or BLYAS adjusted to $0.4\left(\mathrm{OD}_{600}\right)$ in fresh yeast minimal media (YMM leu ${ }^{-}$, ura $^{-}$) was added to each well. A 12-point standard curve of $17 \beta$-estradiol (E2; Sigma-Aldrich Corp.) or testosterone (T; Sigma-Aldrich Corp.) was included on each plate. A media control was included on all plates to establish background luminescence. Plates were covered and incubated in the dark at $30^{\circ} \mathrm{C}$ for 4 hours. Luminescence was quantified using a SpectraMax M4 microplate reader (Molecular Devices), in 
luminescence mode (1,000 millisecond integration time), and relative estrogenicity or androgenicity of each sample was interpolated using a four-parameter curve fit using SoftMax Pro 6.2.2 (Molecular Devices) software. Relative net agonistic activity per liter of sample was then calculated on the basis of sample concentration.

Yeast strain (MCY-105) was used to screen for glucogenicity. Yeast was cultured in synthetic complete drop-out media lacking uracil, tryptophan, and histadine (SC-UWH). The assay was performed similar to that of Balsiger and others (2010) with modification. Yeast was grown at $30^{\circ} \mathrm{C}$ in a rotary incubator for 48 hours. Yeast was diluted to an $\mathrm{OD}_{600}$ of 0.25 , and $95 \mu \mathrm{L}$ of sample was added to wells of a white, solidbottom microplate (Costar). Standards $\left(1.5 \times 10^{4}-8 \mathrm{ng}^{-1 l^{-1}}\right)$ and samples $(5 \mu \mathrm{L})$ were then added, and plates were incubated at $30{ }^{\circ} \mathrm{C}$ for 4 hours. After this incubation, $100 \mu \mathrm{L}$ of Tropix GalScreen in Buffer B (Applied Biosystems, Foster City, California) was added to all wells, and the plate was incubated for an additional 2 hours at $28{ }^{\circ} \mathrm{C}$ according to manufacturer protocols. The hormone-induced chemiluminescent signal was then measured on a SpectraMax M4 microplate reader. Sample concentrations were determined as described above for the BLYES and BLYAS.

\section{EPA National Health and Environmental Effects Laboratory (NHEERL)}

Conley and others (2017a) describe the bioassay methods used in this study to measure estrogen, androgen, and glucocorticoid receptor activity: T47D-KBluc bioassay for estrogenic activity, MDA-kb2 bioassay for androgenic activity, and transduced CV-1 cell bioassay for glucocorticoid activity. In vitro assay data were processed by the EPA and are described in Conley and others (2017b).

\section{Results}

Results from Phase I of the study can be found in the associated data release (Romanok and Bradley, 2018). Selected results for Phase II trace element data can be found in Romanok and others (2018).

\section{References Cited}

Armbruster, D.A., and Pry, T., 2008, Limit of blank, limit of detection and limit of quantitation: Clinical Biochemistry Review, v. 29, Supplemental (i), accessed June 13, 2018, at https://www.ncbi.nlm.nih.gov/pmc/articles/PMC2556583/ pdf/cbr29_s_pgs49.pdf.
Ball, J.W., and McCleskey, R.B., 2003, A new cationexchange method for accurate field speciation of hexavalent chromium: U.S. Geological Survey Water-Resources Investigations Report 03-4018, 17 p., accessed June 13, 2018, at https://wwwbrr.cr.usgs.gov/projects/GWC_chemtherm/ pubs/WRIR\%2003-4018.pdf

Balsiger, H.A., de la Torre, R., Lee, W.-Y., and Cox, M.B., 2010, A four-hour yeast bioassay for the direct measure of estrogenic activity in wastewater without sample extraction, concentration, or sterilization: Science of the Total Environment, v. 408, no. 6, p. 1422-1429, accessed November 13, 2017, at https://doi.org/10.1016/j.scitotenv.2009.12.027.

Bradley, P.M., Journey, C.A., Romanok, K.M., Barber, L.B., Buxton, H.T., Foreman, W.T., Furlong, E.T., Glassmeyer, S.T., Hladik, M.L, Iwanowicz, L.R., Jones, D.K., Kolpin, D.W., Kuivila, K.M., Loftin, K.A., Mills, M.A., Meyer, M.T., Orlando, J.L., Reilly, T.J., Smalling, K.L., and Villeneuve, D.L., 2017, Expanded target-chemical analysis reveals extensive mixed-organic-contaminant exposure in U.S. streams: Environmental Science \& Technology, v. 51 , no. 9 , p. 4792-4802, accessed November 13, 2017, at https://doi.org/10.1021/acs.est.7b00012.

Ciparis, S., Iwanowicz, L.R., and Voshell, J.R., 2012, Effects of watershed densities of animal feeding operations on nutrient concentrations and estrogenic activity in agricultural streams: Science of the Total Environment, v. 414, p. 268-276, accessed August 21, 2018, at https://doi.org/10.1016/j.scitotenv.2011.10.017.

Conley, J.M., Evans, N., Cardon, M.C., Rosenblum, L., Iwanowicz, L.R., Hartig, P.C., Schenck, K.M., Bradley, P.M., and Wilson, V.S., 2017a, Occurrence and in vitro bioactivity of estrogen, androgen, and glucocorticoid compounds in a nationwide screen of United States stream waters: Environmental Science \& Technology, v. 51, no. 9, p. 4781-4791, accessed February 5, 2018, at https://doi.org/10.1021/acs.est.6b06515.

Conley, J.M., Evans, N., Mash, H., Rosenblum, L., Schenck, K.M., Glassmeyer, S., Furlong, E.T., Kolpin, D.W., and Wilson, V.S., 2017b, Comparison of in vitro estrogenic activity and estrogen concentrations in source and treated waters from 25 U.S. drinking water treatment plants: Science of The Total Environment, v. 579 , p. 1610-1617, accessed December 7, 2016, at https://doi.org/10.1016/j.scitotenv.2016.02.093. 
Fishman, M.J., and Friedman, L.C., eds., 1989, Methods for determination of inorganic substances in water and fluvial sediments: U.S. Geological Survey Techniques of WaterResources Investigations, book 5, chap. A1, 545 .

Foreman, W.T., Gray, J.L., ReVello, R.C., Lindley, C.E., Losche, S.A., and Barber, L.B., 2012, Determination of steroid hormones and related compounds in filtered and unfiltered water by solid-phase extraction, derivatization, and gas chromatography with tandem mass spectrometry: U.S. Geological Survey Techniques and Methods, book 5, chap. B9, 118 p.

Furlong, E.T., Noriega, M.C., Kanagy, C.J., Kanagy, L.K., Coffey, L.J., and Burkhardt, M.R., 2014, Determination of human-use pharmaceuticals in filtered water by direct aqueous injection-high-performance liquid chromatography/ tandem mass spectrometry: U.S. Geological Survey Techniques and Methods, book 5, chap. B10, 49 p., accessed June 13, 2018, at https://pubs.usgs.gov/tm/5b10/.

Graham, J.L., Loftin, K.A., Meyer, M.T., and Ziegler, A.C., 2010, Cyanotoxin mixtures and taste-and-odor compounds in cyanobacterial blooms from the Midwestern United States: Environmental Science \& Technology, v. 44, p. 7361-7368, accessed November 13, 2017, at https://pubs.acs.org/doi/ipdf/10.1021/es1008938.

Hergenreder, R.L., 2011, Trace metals in waters by GFAAS, in accordance with U.S. EPA and Health Canada requirements: Shelton, Conn., PerkinElmer, Inc., 5 p.

Hladik, M.L., and Calhoun, D.L., 2012, Analysis of the herbicide diuron, three diuron degradates, and six neonicotinoid insecticides in water-Method details and application to two Georgia streams: U.S. Geological Survey Scientific Investigations Report 2012-5206, 10 p.

Hladik, M.L., Focazio, M.J., and Engle, M., 2014, Discharges of produced waters from oil and gas extraction via wastewater treatment plants are sources of disinfection by-products to receiving streams: Science of The Total Environment, v. 466-467, p. 1085-1093.

Hladik, M.L., Smalling, K.L., and Kuivila, K.M., 2008, A multi-residue method for the analysis of pesticides and pesticide degradates in water using HLB solid-phase extraction and gas chromatography-ion trap mass spectrometry: Bulletin of Environmental Contamination and Toxicology, v. 80, no. 2, p. 139-144, accessed June 13, 2018, at https://doi.org/10.1007/s00128-007-9332-2.

Hoffman, G.L., Fishman, M.J., and Garbarino, J.R., 1996, Methods of analysis by the U.S. Geological Survey National Water Quality Laboratory-In-bottle acid digestion of whole-water samples: U.S. Geological Survey Open-File Report 96-225, $28 \mathrm{p}$.
Lee, E.A., and Strahan, A.P., 2003, Methods of analysis by the U.S. Geological Survey Organic Geochemistry Research Group-Determination of acetamide herbicides and their degradation products in water using online solid-phase extraction and liquid chromatography/mass spectrometry: U.S. Geological Survey Open-File Report 03-173, 17 p.

Loftin, K.A., Graham, J.L., Hilborn, E.D., Lehmann, S.C., Meyer, M.T., Dietze, J.E., and Griffith, C.B., 2016, Cyanotoxins in inland lakes of the United StatesOccurrence and potential recreational health risks in the EPA National Lakes Assessment, 2007: Harmful Algae, v. 56, p. 77-90, accessed November 13, 2017, at https://doi.org/10.1016/j.hal.2016.04.001.

Meyer, M.T., Lee, E.A., Ferrell, G.M., Bumgarner, J.E., and Varns, J., 2007, Evaluation of offline tandem and online solid-phase extraction with liquid chromatography/electrospray ionization-mass spectrometry for analysis of antibiotics in ambient water and comparison to an independent method: U.S. Geological Survey Scientific Investigations Report 2007-5021, p. 28.

Meyer, M.T., Loftin, K.A., Lee, E.A., Hinshaw, G.H., Dietze, J.E., and Scribner, E.A., 2009, Determination of glyphosate, its degradation product aminomethylphosphonic acid, and glufosinate, in water by isotope dilution and online solid-phase extraction and liquid chromatography/tandem mass spectrometry: U.S. Geological Survey Techniques and Methods, book 5, chap. A10, 32 p.

Patton, C.J., and Kryskalla, J.R., 2011, Colorimetric determination of nitrate plus nitrite in water by enzymatic reduction, automated discrete analyzer methods: U.S. Geological Survey Techniques and Methods, book 5, chap. B8, 34 p.

Pfaff, J.D., 1993, Determination of inorganic anions by ion chromatography, Method 300.0, rev. 2.1: U.S. Environmental Protection Agency, accessed November 2, 2017, at https:/www.epa.gov/sites/production/files/2015-08/ documents/method_300-0_rev_2-1_1993.pdf.

Romanok, K.M., and Bradley, P.M., 2018, Target-chemical concentrations, exposure activity ratios, and bioassay results for assessment of mixed-organic/inorganic-chemical exposure in USA tapwater, 2016: U.S. Geological Survey data release, https://doi.org/10.5066/F7959GVJ.

Romanok, K.M., Bradley, P.M., McCleskey, R.B., Meppelink, S.M., Argos, M., and Kolpin, D.W., 2018, Occurrence and concentrations of trace elements in discrete tapwater samples collected in Chicago, Illinois and East Chicago, Indiana, 2017: U.S. Geological Survey data release, accessed November 1, 2018, at https://doi.org/10.5066/ F70R9NN0. 
Rose, D.L., Sandstrom, M.W., and Murtagh, L.K., 2016, Determination of heat purgeable and ambient purgeable volatile organic compounds in water by gas chromatography/mass spectrometry: U.S. Geological Survey Techniques and Methods, book 5, chap. B12, 61 p., accessed June 13, 2018, at https://doi.org/10.3133/tm5B12.

Sanseverino. J., Eldridge, M.L., Layton, A.C., Easter, J.P., Yarborough, J., Shultz, T.W., and Sayler, G.S., 2009, Screening of potentially hormonally active chemicals using bioluminescent yeast bioreporters: Toxicological Sciences, v. 107, p. 122-134, accessed June 13, 2018, at https://doi.org/10.1093/toxsci/kfn229.

Sanseverino, J., Gupta, R.K., Layton, A.C., Patterson, S.S., Ripp, S.A., Saidak, L., Simpson, M.L., Schultz, T.W., and Sayler, G.S., 2005, Use of Saccharomyces cerevisiae BLYES expressing bacterial bioluminescence for rapid, sensitive detection of estrogenic compounds: Applied Environmental Microbiology, v. 71, no. 8, p. 4455-4460, accessed June 13, 2018, at https://doi.org/10.1128/AEM.71.8.44554460.2005 .

U.S. Environmental Protection Agency [EPA], 2014, Inductively coupled plasma - optical emission spectrometry, Method 6010D: U.S. Environmental Protection Agency, EPA SW-846 Update V, accessed November 2, 2017, at https://www.epa.gov/sites/production/files/2015-12/ documents/6010d.pdf.

U.S. Environmental Protection Agency [EPA], 2017, Method for extraction and analysis of perfluoroether carboxylic acids (PFECAs) from surface water, well water and waste water by ultra-high performance liquid chromatography (UPLC)-tandem mass spectrometry (MS/MS): U.S. Environmental Protection Agency, Office of Research and Development, National Exposure Research Laboratory, D-EMMD-PHCB-062-SOP-01, July 5, 2017, 26 p.

U.S. Geological Survey, variously dated, National field manual for the collection of water-quality data: U.S. Geological Survey Techniques of Water-Resources Investigations, book 9, chaps. A1-A10, accessed November 3, 2016, at https://pubs.water.usgs.gov/twri9A.

U.S. Geological Survey, 2015, Changes to National Water Quality Laboratory (NWQL) procedures used to establish and verify laboratory detection and reporting limits: U.S. Geological Survey National Water Quality Laboratory Technical Memorandum 15.02, accessed June 13, 2018, at https://nwql.usgs.gov/tech_memos/nwql.2015-02.pdf.
Yost, E.E., Meyer, M.T., Dietze, J.E., Williams, C.M., WorleyDavis, L., Lee, B., and Kullman, S.W., 2014, Transport of steroid hormones, phytoestrogens, and estrogenic activity across a swine lagoon/sprayfield system: Environmental Science \& Technology, v. 48, no. 19, p. 11600-11609, accessed June 13, 2018, at https://doi.org/10.1021/ es5025806.

Yost, E.E., Meyer, M.T., Dietze, J.E., Meissner, B.M., Worley-Davis, L., Williams, C.M., Boknam, L., and Kullman, S.W., 2013, Comprehensive assessment of hormones, phytoestrogens, and estrogenic activity in an anaerobic swine waste lagoon: Environmental Science \& Technology, v. 47, no. 23, p. 13781-13790, accessed October 31, 2018, at https://doi.org/10.1021/es4026408. 


\section{Methods Used for the Collection and Analysis of Chemical and Biological Data for the Tapwater Exposure Study}

Table 1. Site information for samples collected as part of the U.S. Geological Survey (USGS) Environmental Health Mission Area, Infrastructure Project, Tapwater Exposure Study, 2016-17.

[Samples were collected between May and September 2016 for Phase I and during two trips between August and December 2017 for Phase II. WDS, water distribution system; pre-WDS, collected prior to any treatment; PS, private supply; GW, groundwater; SW, surface water; LK, lake; -, unknown]

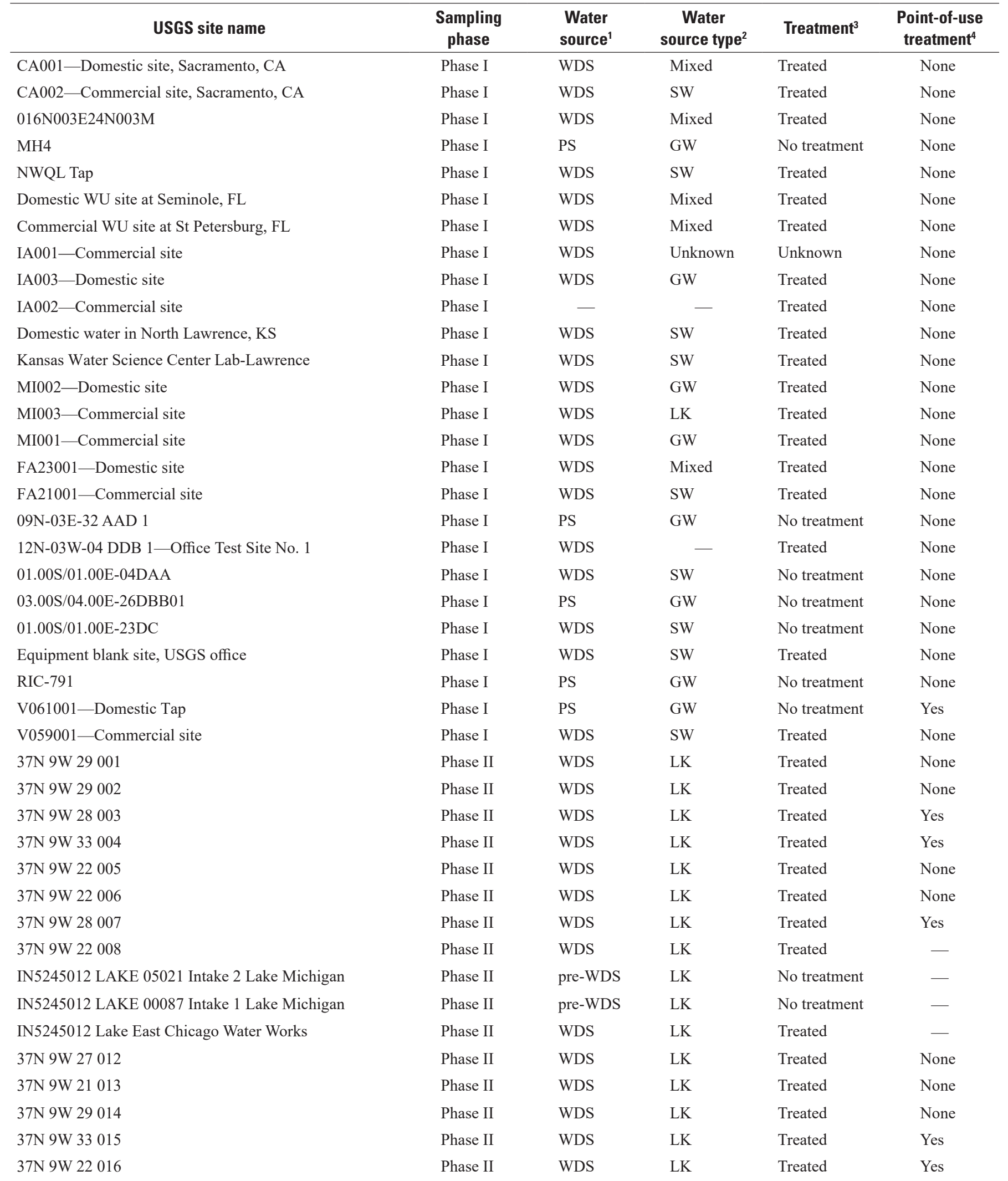


Table 1. Site information for samples collected as part of the U.S. Geological Survey (USGS) Environmental Health Mission Area, Infrastructure Project, Tapwater Exposure Study, 2016-17.-Continued

[Samples were collected between May and September 2016 for Phase I and during two trips between August and December 2017 for Phase II. WDS, water distribution system; pre-WDS, collected prior to any treatment; PS, private supply; GW, groundwater; SW, surface water; LK, lake; -, unknown]

\begin{tabular}{|c|c|c|c|c|c|}
\hline USGS site name & $\begin{array}{c}\text { Sampling } \\
\text { phase }\end{array}$ & $\begin{array}{l}\text { Water } \\
\text { source }^{1}\end{array}$ & $\begin{array}{c}\text { Water } \\
\text { source type }\end{array}$ & Treatment $^{3}$ & $\begin{array}{c}\text { Point-of-use } \\
\text { treatment }{ }^{4}\end{array}$ \\
\hline 37N 9W 27017 & Phase II & WDS & LK & Treated & Yes \\
\hline $37 \mathrm{~N} 9 \mathrm{~W} 27018$ & Phase II & WDS & LK & Treated & None \\
\hline $37 \mathrm{~N} 9 \mathrm{~W} 27019$ & Phase II & WDS & LK & Treated & None \\
\hline $39 \mathrm{~N}-14 \mathrm{E}-10001$ & Phase II & pre-WDS & LK & No treatment & - \\
\hline $39 \mathrm{~N}-14 \mathrm{E}-10002$ & Phase II & WDS & LK & Treated & - \\
\hline $38 \mathrm{~N}-15 \mathrm{E}-29001$ & Phase II & pre-WDS & LK & No treatment & - \\
\hline $38 \mathrm{~N}-15 \mathrm{E}-29002$ & Phase II & WDS & LK & Treated & - \\
\hline $37 \mathrm{~N} 15 \mathrm{E} 6020$ & Phase II & WDS & LK & Treated & None \\
\hline $37 \mathrm{~N} 15 \mathrm{E} 18021$ & Phase II & WDS & LK & Treated & None \\
\hline $37 \mathrm{~N} 15 \mathrm{E} 7022$ & Phase II & WDS & LK & Treated & None \\
\hline $37 \mathrm{~N} 14 \mathrm{E} 7023$ & Phase II & WDS & LK & Treated & Yes \\
\hline $37 \mathrm{~N} 14 \mathrm{E} 7024$ & Phase II & WDS & LK & Treated & None \\
\hline $40 \mathrm{~N} 14 \mathrm{E} 28025$ & Phase II & WDS & LK & Treated & None \\
\hline 40N 13E 36026 & Phase II & WDS & LK & Treated & None \\
\hline 40N 13E 25027 & Phase II & WDS & LK & Treated & None \\
\hline 40N 13E 36028 & Phase II & WDS & LK & Treated & None \\
\hline 40N 13E 36029 & Phase II & WDS & LK & Treated & None \\
\hline 40N 13E 25030 & Phase II & WDS & LK & Treated & None \\
\hline 40N 13E 15031 & Phase II & WDS & LK & Treated & None \\
\hline 40N 13E 11032 & Phase II & WDS & LK & Treated & None \\
\hline 40N 13E 13033 & Phase II & WDS & LK & Treated & None \\
\hline 40N 14E 17034 & Phase II & WDS & LK & Treated & None \\
\hline 40N 13E 32038 & Phase II & WDS & LK & Treated & None \\
\hline 39N 13E 01039 & Phase II & WDS & LK & Treated & None \\
\hline 40N 14E 08040 & Phase II & WDS & LK & Treated & None \\
\hline 41N 14E 32041 & Phase II & WDS & LK & Treated & None \\
\hline 38N 14E 2042 & Phase II & WDS & LK & Treated & None \\
\hline $38 \mathrm{~N} 14 \mathrm{E} 3043$ & Phase II & WDS & LK & Treated & None \\
\hline $38 \mathrm{~N} 14 \mathrm{E} 20044$ & Phase II & WDS & LK & Treated & None \\
\hline $38 \mathrm{~N} 13 \mathrm{E} 34045$ & Phase II & WDS & LK & Treated & None \\
\hline $38 \mathrm{~N}$ 14E 11046 & Phase II & WDS & LK & Treated & None \\
\hline $38 \mathrm{~N} 14 \mathrm{E} 12047$ & Phase II & WDS & LK & Treated & None \\
\hline 38N 14E 11048 & Phase II & WDS & LK & Treated & None \\
\hline 38N 14E 11049 & Phase II & WDS & LK & Treated & None \\
\hline $38 \mathrm{~N} 14 \mathrm{E} 14050$ & Phase II & WDS & LK & Treated & None \\
\hline $38 \mathrm{~N} 14 \mathrm{E} 12051$ & Phase II & WDS & LK & Treated & None \\
\hline $38 \mathrm{~N}$ 14E 11052 & Phase II & WDS & LK & Treated & None \\
\hline
\end{tabular}

${ }^{1}$ Denotes whether water-quality sample was collected from a private supply (PS), a treated distribution source (WDS), or a raw-water intake (pre-WDS).

${ }^{2}$ Denotes primary source of water (groundwater [GW], surface water [SW], or lake [LK]).

${ }^{3}$ Denotes whether water is treated prior to distribution.

${ }^{4}$ Denotes whether point-of-use (at the tap) treatment equipment was present at the time of sample collection. Does not in any way indicate effectiveness, or condition, of system. 
Table 2. Chemical compound information for analyses performed by various laboratories for the U.S. Geological Survey, Environmental Health Mission Area, Infrastructure Project, Tapwater Exposure Pilot Study, 2016-17.

[NWIS, National Water Information System; CAS, Chemical Abstract Services; y, year; NA, not available; EPA, U.S. Environmental Protection Agency; RED01, enzyme reduction-diazotization; GC, gas chromatograph; LC, liquid chromatography; ICP-MS, inductively coupled plasma-mass spectrometry; cICP-MS, cell inductively coupled plasma-mass spectrometry; HPLC/MS-MS, high performance liquid chromatography/tandem mass spectrometry; HCO3, bicarbonate; $\mu \mathrm{S} / \mathrm{cm}$, microsiemens per centimeter; $\mu \mathrm{g} / \mathrm{L}$, micrograms per liter; $\mathrm{mg} / \mathrm{L}$, milligrams per liter; ng/L, nanograms per liter; DAI-LC/MS-MS, direct aqueous injection-liquid chromatography/tandem mass spectrometry; ICP-OES, inductively coupled plasma-optical emission spectrometry; IC, ion chromatography; GCM66, ambient purgeable method (GC/MS); GM016, heat purgeable method (GC/MS); GC/MS-MS, gas chromatography/tandem mass spectrometry; LC/MS-MS, liquid chromatography-tandem mass spectrometry; ELISA, enzyme linked immunosorbent assay for algal toxins; MDL, method detection limit; MRL, minimum reporting level; IRL, interim reporting level; LOQ, limit of quantification; RLDQC, reporting limit by (DQCALC)]

\begin{tabular}{|c|c|c|c|c|}
\hline Compound & CAS number & Compound class & $\begin{array}{c}\text { Year } \\
\text { collected } \\
\text { (yyyy) }\end{array}$ & Analyzing laboratory \\
\hline Erythromycin- $\mathrm{H} 2 \mathrm{O}$ & $23893-13-2$ & Degradation product/Macrolides & 2016 and 2017 & $\begin{array}{l}\text { Organic Geochemisty Research } \\
\text { Laboratory, Kansas }\end{array}$ \\
\hline Epi-chlorotetracycline & $101342-45-4$ & Degradation product/Tetracyclines & 2016 and 2017 & $\begin{array}{l}\text { Organic Geochemisty Research } \\
\text { Laboratory, Kansas }\end{array}$ \\
\hline Epi-oxytetracycline & $35259-39-3$ & Degradation product/Tetracyclines & 2016 and 2017 & $\begin{array}{l}\text { Organic Geochemisty Research } \\
\text { Laboratory, Kansas }\end{array}$ \\
\hline Epi-tetracycline & $79-85-6$ & Degradation product/Tetracyclines & 2016 and 2017 & $\begin{array}{l}\text { Organic Geochemisty Research } \\
\text { Laboratory, Kansas }\end{array}$ \\
\hline Iso-chlorotetracycline & $514-53-4$ & Degradation product/Tetracyclines & 2016 and 2017 & $\begin{array}{l}\text { Organic Geochemisty Research } \\
\text { Laboratory, Kansas }\end{array}$ \\
\hline Enrofloxacin & $93106-60-6$ & Pharmaceutically active/Fluoroquinolines & 2016 and 2017 & $\begin{array}{l}\text { Organic Geochemisty Research } \\
\text { Laboratory, Kansas }\end{array}$ \\
\hline Lomefloxacin & $98079-51-7$ & Pharmaceutically active/Fluoroquinolines & 2016 and 2017 & $\begin{array}{l}\text { Organic Geochemisty Research } \\
\text { Laboratory, Kansas }\end{array}$ \\
\hline Norfloxacin & $70458-96-7$ & Pharmaceutically active/Fluoroquinolines & 2016 and 2017 & $\begin{array}{l}\text { Organic Geochemisty Research } \\
\text { Laboratory, Kansas }\end{array}$ \\
\hline Ofloxacin & $82419-36-1$ & Pharmaceutically active/Fluoroquinolines & 2016 and 2017 & $\begin{array}{l}\text { Organic Geochemisty Research } \\
\text { Laboratory, Kansas }\end{array}$ \\
\hline Sarafloxacin & $98105-99-8$ & Pharmaceutically active/Fluoroquinolines & 2016 and 2017 & $\begin{array}{l}\text { Organic Geochemisty Research } \\
\text { Laboratory, Kansas }\end{array}$ \\
\hline Virginiamycin & $11006-76-1$ & Pharmaceutically active/Macrolides & 2016 and 2017 & $\begin{array}{l}\text { Organic Geochemisty Research } \\
\text { Laboratory, Kansas }\end{array}$ \\
\hline Chloramphenicol & $56-75-7$ & Pharmaceutically active/other & 2016 and 2017 & $\begin{array}{l}\text { Organic Geochemisty Research } \\
\text { Laboratory, Kansas }\end{array}$ \\
\hline Lincomycin & $154-21-2$ & Pharmaceutically active/other & 2016 and 2017 & $\begin{array}{l}\text { Organic Geochemisty Research } \\
\text { Laboratory, Kansas }\end{array}$ \\
\hline Ormetoprim & $6981-18-6$ & Pharmaceutically active/other & 2016 and 2017 & $\begin{array}{l}\text { Organic Geochemisty Research } \\
\text { Laboratory, Kansas }\end{array}$ \\
\hline
\end{tabular}


Table 2. Chemical compound information for analyses performed by various laboratories for the U.S. Geological Survey, Environmental Health Mission Area, Infrastructure Project, Tapwater Exposure Pilot Study, 2016-17. —Continued

[NWIS, National Water Information System; CAS, Chemical Abstract Services; y, year; NA, not available; EPA, U.S. Environmental Protection Agency; RED01, enzyme reduction-diazotization; GC, gas chromatograph; LC, liquid chromatography; ICP-MS, inductively coupled plasma- mass spectrometry; cICP-MS, cell inductively coupled plasma-mass spectrometry; HPLC/MS-MS, high performance liquid chromatography-tandem mass spectrometry; HCO3, bicarbonate; $\mu \mathrm{S} / \mathrm{cm}$, microsiemens per centimeter; $\mu \mathrm{g} / \mathrm{L}$, micrograms per liter; mg/L, milligrams per liter; ng/L, nanograms per liter; DAI-LC/MS-MS, direct aqueous injection-liquid chromatography/tandem mass spectrometry; ICP-OES, inductively coupled plasma-optical emission spectrometry; IC, ion chromatography; GCM66, ambient purgeable method (GC/MS); GM016, heat purgeable method (GC/MS); GC/MS-MS, gas chromatography, tandem mass spectrometry; LC/MS-MS, liquid chromatography-tandem mass spectrometry; ELISA, enzyme linked immunosorbent assay for algal toxins; MDL, method detection limit; MRL, minimum reporting level; IRL, interim reporting level; LOQ, limit of quantification; RLDQC, reporting limit by (DQCALC)]

\begin{tabular}{|c|c|c|c|c|c|c|}
\hline $\begin{array}{c}\text { NWIS } \\
\text { Parameter } \\
\text { code }\end{array}$ & $\begin{array}{l}\text { Laboratory } \\
\text { method code }\end{array}$ & $\begin{array}{c}\text { Reporting } \\
\text { limit }^{1} \\
(2016)\end{array}$ & $\begin{array}{c}\text { Reporting } \\
\text { limit }^{1} \\
(2017)\end{array}$ & Units & $\begin{array}{c}\text { Method of } \\
\text { quantitation }\end{array}$ & Reference cited \\
\hline 63674 & LC/MS-MS & 0.005 & 0.005 & $\mu \mathrm{g} / \mathrm{L}$ & LOQ & Meyer and others, 2007 (modified) \\
\hline 63731 & LC/MS-MS & 0.010 & 0.010 & $\mu \mathrm{g} / \mathrm{L}$ & LOQ & Meyer and others, 2007 (modified) \\
\hline 63729 & LC/MS-MS & 0.010 & 0.010 & $\mu \mathrm{g} / \mathrm{L}$ & LOQ & Meyer and others, 2007 (modified) \\
\hline 63727 & LC/MS-MS & 0.010 & 0.010 & $\mu \mathrm{g} / \mathrm{L}$ & LOQ & Meyer and others, 2007 (modified) \\
\hline 64175 & LC/MS-MS & 0.010 & 0.010 & $\mu \mathrm{g} / \mathrm{L}$ & LOQ & Meyer and others, 2007 (modified) \\
\hline 66495 & LC/MS-MS & 0.005 & 0.005 & $\mu \mathrm{g} / \mathrm{L}$ & LOQ & Meyer and others, 2007 (modified) \\
\hline 62900 & LC/MS-MS & 0.005 & 0.005 & $\mu \mathrm{g} / \mathrm{L}$ & LOQ & Meyer and others, 2007 (modified) \\
\hline 62757 & LC/MS-MS & 0.005 & 0.005 & $\mu \mathrm{g} / \mathrm{L}$ & LOQ & Meyer and others, 2007 (modified) \\
\hline 62899 & LC/MS-MS & 0.005 & 0.005 & $\mu \mathrm{g} / \mathrm{L}$ & LOQ & Meyer and others, 2007 (modified) \\
\hline 62771 & LC/MS-MS & 0.005 & 0.005 & $\mu \mathrm{g} / \mathrm{L}$ & LOQ & Meyer and others, 2007 (modified) \\
\hline 62897 & LC/MS-MS & 0.005 & 0.005 & $\mu \mathrm{g} / \mathrm{L}$ & LOQ & Meyer and others, 2007 (modified) \\
\hline 65194 & LC/MS-MS & 0.100 & 0.100 & $\mu \mathrm{g} / \mathrm{L}$ & LOQ & Meyer and others, 2007 (modified) \\
\hline 62894 & LC/MS-MS & 0.005 & 0.005 & $\mu \mathrm{g} / \mathrm{L}$ & LOQ & Meyer and others, 2007 (modified) \\
\hline 62962 & LC/MS-MS & 0.005 & 0.005 & $\mu \mathrm{g} / \mathrm{L}$ & LOQ & Meyer and others, 2007 (modified) \\
\hline
\end{tabular}


Table 2. Chemical compound information for analyses performed by various laboratories for the U.S. Geological Survey, Environmental Health Mission Area, Infrastructure Project, Tapwater Exposure Pilot Study, 2016-17._Continued

[NWIS, National Water Information System; CAS, Chemical Abstract Services; y, year; NA, not available; EPA, U.S. Environmental Protection Agency; RED01, enzyme reduction-diazotization; GC, gas chromatograph; LC, liquid chromatography; ICP-MS, inductively coupled plasma-mass spectrometry; cICP-MS, cell inductively coupled plasma-mass spectrometry; HPLC/MS-MS, high performance liquid chromatography/tandem mass spectrometry; HCO3, bicarbonate; $\mu \mathrm{S} / \mathrm{cm}$, microsiemens per centimeter; $\mu \mathrm{g} / \mathrm{L}$, micrograms per liter; $\mathrm{mg} / \mathrm{L}$, milligrams per liter; ng/L, nanograms per liter; DAI-LC/MS-MS, direct aqueous injection-liquid chromatography/tandem mass spectrometry; ICP-OES, inductively coupled plasma-optical emission spectrometry; IC, ion chromatography; GCM66, ambient purgeable method (GC/MS); GM016, heat purgeable method (GC/MS); GC/MS-MS, gas chromatography/tandem mass spectrometry; LC/MS-MS, liquid chromatography-tandem mass spectrometry; ELISA, enzyme linked immunosorbent assay for algal toxins; MDL, method detection limit; MRL, minimum reporting level; IRL, interim reporting level; LOQ, limit of quantification; RLDQC, reporting limit by (DQCALC)]

\begin{tabular}{|c|c|c|c|c|}
\hline Compound & CAS number & Compound class & $\begin{array}{c}\text { Year } \\
\text { collected } \\
\text { (yyyy) }\end{array}$ & Analyzing laboratory \\
\hline Trimethoprim & $738-70-5$ & Pharmaceutically active/other & 2016 and 2017 & $\begin{array}{l}\text { Organic Geochemisty Research } \\
\text { Laboratory, Kansas }\end{array}$ \\
\hline Carbamazepine & $298-46-4$ & Pharmaceutically active/Pharmaceuticals & 2016 and 2017 & $\begin{array}{l}\text { Organic Geochemisty Research } \\
\text { Laboratory, Kansas }\end{array}$ \\
\hline Sulfachloropyridazine & $80-32-0$ & Pharmaceutically active/Sulfonamides & 2016 and 2017 & $\begin{array}{l}\text { Organic Geochemisty Research } \\
\text { Laboratory, Kansas }\end{array}$ \\
\hline Sulfadiazine & $68-35-9$ & Pharmaceutically active/Sulfonamides & 2016 and 2017 & $\begin{array}{l}\text { Organic Geochemisty Research } \\
\text { Laboratory, Kansas }\end{array}$ \\
\hline Sulfadimethoxine & $122-11-2$ & Pharmaceutically active/Sulfonamides & 2016 and 2017 & $\begin{array}{l}\text { Organic Geochemisty Research } \\
\text { Laboratory, Kansas }\end{array}$ \\
\hline Sulfamethoxazole & $723-46-6$ & Pharmaceutically active/Sulfonamides & 2016 and 2017 & $\begin{array}{l}\text { Organic Geochemisty Research } \\
\text { Laboratory, Kansas }\end{array}$ \\
\hline Sulfathiazole & $72-14-0$ & Pharmaceutically active/Sulfonamides & 2016 and 2017 & $\begin{array}{l}\text { Organic Geochemisty Research } \\
\text { Laboratory, Kansas }\end{array}$ \\
\hline Chlorotetracycline & $64-72-2$ & Pharmaceutically active/Tetracyclines & 2016 and 2017 & $\begin{array}{l}\text { Organic Geochemisty Research } \\
\text { Laboratory, Kansas }\end{array}$ \\
\hline Doxycycline & $564-25-0$ & Pharmaceutically active/Tetracyclines & 2016 and 2017 & $\begin{array}{l}\text { Organic Geochemisty Research } \\
\text { Laboratory, Kansas }\end{array}$ \\
\hline Oxytetracycline & $6153-64-6$ & Pharmaceutically active/Tetracyclines & 2016 and 2017 & $\begin{array}{l}\text { Organic Geochemisty Research } \\
\text { Laboratory, Kansas }\end{array}$ \\
\hline $\begin{array}{l}\text { Acetochlor ESA (ethane } \\
\text { sulfonic acid) }\end{array}$ & $187022-11-3$ & Pesticide degradation product & 2016 and 2017 & $\begin{array}{l}\text { Organic Geochemisty Research } \\
\text { Laboratory, Kansas }\end{array}$ \\
\hline Acetochlor hydroxy & NA & Pesticide degradation product & 2016 and 2017 & $\begin{array}{l}\text { Organic Geochemisty Research } \\
\text { Laboratory, Kansas }\end{array}$ \\
\hline $\begin{array}{l}\text { Acetochlor OXA (oxanilic } \\
\text { acid) }\end{array}$ & $194992-44-4$ & Pesticide degradation product & 2016 and 2017 & $\begin{array}{l}\text { Organic Geochemisty Research } \\
\text { Laboratory, Kansas }\end{array}$ \\
\hline $\begin{array}{l}\text { Acetochlor SAA (sulfynil } \\
\text { acetic acid) }\end{array}$ & NA & Pesticide degradation product & 2016 and 2017 & $\begin{array}{l}\text { Organic Geochemisty Research } \\
\text { Laboratory, Kansas }\end{array}$ \\
\hline
\end{tabular}


Table 2. 17

Table 2. Chemical compound information for analyses performed by various laboratories for the U.S. Geological Survey, Environmental Health Mission Area, Infrastructure Project, Tapwater Exposure Pilot Study, 2016-17. —Continued

[NWIS, National Water Information System; CAS, Chemical Abstract Services; y, year; NA, not available; EPA, U.S. Environmental Protection Agency; RED01, enzyme reduction-diazotization; GC, gas chromatograph; LC, liquid chromatography; ICP-MS, inductively coupled plasma- mass spectrometry; cICP-MS, cell inductively coupled plasma-mass spectrometry; HPLC/MS-MS, high performance liquid chromatography-tandem mass spectrometry; HCO3, bicarbonate; $\mu \mathrm{S} / \mathrm{cm}$, microsiemens per centimeter; $\mu \mathrm{g} / \mathrm{L}$, micrograms per liter; mg/L, milligrams per liter; ng/L, nanograms per liter; DAI-LC/MS-MS, direct aqueous injection-liquid chromatography/tandem mass spectrometry; ICP-OES, inductively coupled plasma-optical emission spectrometry; IC, ion chromatography; GCM66, ambient purgeable method (GC/MS); GM016, heat purgeable method (GC/MS); GC/MS-MS, gas chromatography, tandem mass spectrometry; LC/MS-MS, liquid chromatography-tandem mass spectrometry; ELISA, enzyme linked immunosorbent assay for algal toxins; MDL, method detection limit; MRL, minimum reporting level; IRL, interim reporting level; LOQ, limit of quantification; RLDQC, reporting limit by (DQCALC)]

\begin{tabular}{|c|c|c|c|c|c|c|}
\hline $\begin{array}{c}\text { NWIS } \\
\text { Parameter } \\
\text { code }\end{array}$ & $\begin{array}{l}\text { Laboratory } \\
\text { method code }\end{array}$ & $\begin{array}{c}\text { Reporting } \\
\text { limit }^{1} \\
(2016)\end{array}$ & $\begin{array}{c}\text { Reporting } \\
\text { limit }^{1} \\
(2017)\end{array}$ & Units & $\begin{array}{c}\text { Method of } \\
\text { quantitation }\end{array}$ & Reference cited \\
\hline 62023 & LC/MS-MS & 0.005 & 0.005 & $\mu \mathrm{g} / \mathrm{L}$ & LOQ & Meyer and others, 2007 (modified) \\
\hline 62793 & LC/MS-MS & 0.005 & 0.005 & $\mu \mathrm{g} / \mathrm{L}$ & LOQ & Meyer and others, 2007 (modified) \\
\hline 62774 & LC/MS-MS & 0.005 & 0.005 & $\mu \mathrm{g} / \mathrm{L}$ & LOQ & Meyer and others, 2007 (modified) \\
\hline 62963 & LC/MS-MS & 0.100 & 0.100 & $\mu \mathrm{g} / \mathrm{L}$ & LOQ & Meyer and others, 2007 (modified) \\
\hline 62776 & LC/MS-MS & 0.005 & 0.005 & $\mu \mathrm{g} / \mathrm{L}$ & LOQ & Meyer and others, 2007 (modified) \\
\hline 62775 & LC/MS-MS & 0.005 & 0.005 & $\mu \mathrm{g} / \mathrm{L}$ & LOQ & Meyer and others, 2007 (modified) \\
\hline 62778 & LC/MS-MS & 0.050 & 0.050 & $\mu \mathrm{g} / \mathrm{L}$ & LOQ & Meyer and others, 2007 (modified) \\
\hline 61744 & LC/MS-MS & 0.010 & 0.010 & $\mu \mathrm{g} / \mathrm{L}$ & LOQ & Meyer and others, 2007 (modified) \\
\hline 62694 & LC/MS-MS & 0.010 & 0.010 & $\mu \mathrm{g} / \mathrm{L}$ & LOQ & Meyer and others, 2007 (modified) \\
\hline 61759 & LC/MS-MS & 0.010 & 0.010 & $\mu \mathrm{g} / \mathrm{L}$ & LOQ & Meyer and others, 2007 (modified) \\
\hline 61029 & LC/MS-MS & 0.02 & 0.02 & $\mu \mathrm{g} / \mathrm{L}$ & LOQ & Lee and Strahan, 2003 (modified) \\
\hline 63784 & LC/MS-MS & 0.02 & 0.02 & $\mu \mathrm{g} / \mathrm{L}$ & LOQ & Lee and Strahan, 2003 (modified) \\
\hline 61030 & LC/MS-MS & 0.02 & 0.02 & $\mu \mathrm{g} / \mathrm{L}$ & LOQ & Lee and Strahan, 2003 (modified) \\
\hline 62847 & LC/MS-MS & 0.02 & 0.02 & $\mu \mathrm{g} / \mathrm{L}$ & LOQ & Lee and Strahan, 2003 (modified) \\
\hline
\end{tabular}


Table 2. Chemical compound information for analyses performed by various laboratories for the U.S. Geological Survey, Environmental Health Mission Area, Infrastructure Project, Tapwater Exposure Pilot Study, 2016-17.-Continued

[NWIS, National Water Information System; CAS, Chemical Abstract Services; y, year; NA, not available; EPA, U.S. Environmental Protection Agency; RED01, enzyme reduction-diazotization; GC, gas chromatograph; LC, liquid chromatography; ICP-MS, inductively coupled plasma-mass spectrometry; cICP-MS, cell inductively coupled plasma-mass spectrometry; HPLC/MS-MS, high performance liquid chromatography/tandem mass spectrometry; HCO3, bicarbonate; $\mu \mathrm{S} / \mathrm{cm}$, microsiemens per centimeter; $\mu \mathrm{g} / \mathrm{L}$, micrograms per liter; $\mathrm{mg} / \mathrm{L}$, milligrams per liter; ng/L, nanograms per liter; DAI-LC/MS-MS, direct aqueous injection-liquid chromatography/tandem mass spectrometry; ICP-OES, inductively coupled plasma-optical emission spectrometry; IC, ion chromatography; GCM66, ambient purgeable method (GC/MS); GM016, heat purgeable method (GC/MS); GC/MS-MS, gas chromatography/tandem mass spectrometry; LC/MS-MS, liquid chromatography-tandem mass spectrometry; ELISA, enzyme linked immunosorbent assay for algal toxins; MDL, method detection limit; MRL, minimum reporting level; IRL, interim reporting level; LOQ, limit of quantification; RLDQC, reporting limit by (DQCALC)]

\begin{tabular}{|c|c|c|c|c|}
\hline Compound & CAS number & Compound class & $\begin{array}{c}\text { Year } \\
\text { collected } \\
\text { (yyyy) }\end{array}$ & Analyzing laboratory \\
\hline $\begin{array}{l}\text { Acetochlor/metolachlor }-2 \text { nd } \\
\text { amide }\end{array}$ & $32428-71-0$ & Pesticide degradation product & 2016 and 2017 & $\begin{array}{l}\text { Organic Geochemisty Research } \\
\text { Laboratory, Kansas }\end{array}$ \\
\hline $\begin{array}{l}\text { Acetochlor/metolachlor } \\
\text { ESA - 2nd amide }\end{array}$ & $446027-17-4$ & Pesticide degradation product & 2016 and 2017 & $\begin{array}{l}\text { Organic Geochemisty Research } \\
\text { Laboratory, Kansas }\end{array}$ \\
\hline Alachlor - 2nd amide & $6967-29-9$ & Pesticide degradation product & 2016 and 2017 & $\begin{array}{l}\text { Organic Geochemisty Research } \\
\text { Laboratory, Kansas }\end{array}$ \\
\hline Alachlor deschloro & $142363-53-9$ & Pesticide degradation product & 2016 and 2017 & $\begin{array}{l}\text { Organic Geochemisty Research } \\
\text { Laboratory, Kansas }\end{array}$ \\
\hline Alachlor ESA & $140939-15-7$ & Pesticide degradation product & 2016 and 2017 & $\begin{array}{l}\text { Organic Geochemisty Research } \\
\text { Laboratory, Kansas }\end{array}$ \\
\hline Alachlor OXA & $171262-17-2$ & Pesticide degradation product & 2016 and 2017 & $\begin{array}{l}\text { Organic Geochemisty Research } \\
\text { Laboratory, Kansas }\end{array}$ \\
\hline Alachlor SAA & 494847-39-1 & Pesticide degradation product & 2016 and 2017 & $\begin{array}{l}\text { Organic Geochemisty Research } \\
\text { Laboratory, Kansas }\end{array}$ \\
\hline Alachlor ESA - 2nd amide & NA & Pesticide degradation product & 2016 and 2017 & $\begin{array}{l}\text { Organic Geochemisty Research } \\
\text { Laboratory, Kansas }\end{array}$ \\
\hline Dimethenamid & $87674-68-8$ & Pesticide & 2016 and 2017 & $\begin{array}{l}\text { Organic Geochemisty Research } \\
\text { Laboratory, Kansas }\end{array}$ \\
\hline Dimethenamid deschloro & $864182-54-7$ & Pesticide degradation product & 2016 and 2017 & $\begin{array}{l}\text { Organic Geochemisty Research } \\
\text { Laboratory, Kansas }\end{array}$ \\
\hline Flufenacet ESA & $201668-32-8$ & Pesticide degradation product & 2016 and 2017 & $\begin{array}{l}\text { Organic Geochemisty Research } \\
\text { Laboratory, Kansas }\end{array}$ \\
\hline Flufenacet OXA & $201668-31-7$ & Pesticide degradation product & 2016 and 2017 & $\begin{array}{l}\text { Organic Geochemisty Research } \\
\text { Laboratory, Kansas }\end{array}$ \\
\hline Metolachlor & $51218-45-2$ & Pesticide & 2016 and 2017 & $\begin{array}{l}\text { Organic Geochemisty Research } \\
\text { Laboratory, Kansas }\end{array}$ \\
\hline Metolachlor deschloro & $126605-22-9$ & Pesticide degradation product & 2016 and 2017 & $\begin{array}{l}\text { Organic Geochemisty Research } \\
\text { Laboratory, Kansas }\end{array}$ \\
\hline
\end{tabular}


Table 2. 19

Table 2. Chemical compound information for analyses performed by various laboratories for the U.S. Geological Survey, Environmental Health Mission Area, Infrastructure Project, Tapwater Exposure Pilot Study, 2016-17. —Continued

[NWIS, National Water Information System; CAS, Chemical Abstract Services; y, year; NA, not available; EPA, U.S. Environmental Protection Agency; RED01, enzyme reduction-diazotization; GC, gas chromatograph; LC, liquid chromatography; ICP-MS, inductively coupled plasma- mass spectrometry; cICP-MS, cell inductively coupled plasma-mass spectrometry; HPLC/MS-MS, high performance liquid chromatography-tandem mass spectrometry; HCO3, bicarbonate; $\mu \mathrm{S} / \mathrm{cm}$, microsiemens per centimeter; $\mu \mathrm{g} / \mathrm{L}$, micrograms per liter; $\mathrm{mg} / \mathrm{L}$, milligrams per liter; ng/L, nanograms per liter; DAI-LC/MS-MS, direct aqueous injection-liquid chromatography/tandem mass spectrometry; ICP-OES, inductively coupled plasma-optical emission spectrometry; IC, ion chromatography; GCM66, ambient purgeable method (GC/MS); GM016, heat purgeable method (GC/MS); GC/MS-MS, gas chromatography, tandem mass spectrometry; LC/MS-MS, liquid chromatography-tandem mass spectrometry; ELISA, enzyme linked immunosorbent assay for algal toxins; MDL, method detection limit; MRL, minimum reporting level; IRL, interim reporting level; LOQ, limit of quantification; RLDQC, reporting limit by (DQCALC)]

\begin{tabular}{|c|c|c|c|c|c|c|}
\hline $\begin{array}{c}\text { NWIS } \\
\text { Parameter } \\
\text { code }\end{array}$ & $\begin{array}{l}\text { Laboratory } \\
\text { method code }\end{array}$ & $\begin{array}{c}\text { Reporting } \\
\text { limit' }^{1} \\
(2016)\end{array}$ & $\begin{array}{c}\text { Reporting } \\
\text { limit }^{1} \\
(2017)\end{array}$ & Units & $\begin{array}{c}\text { Method of } \\
\text { quantitation }\end{array}$ & Reference cited \\
\hline 63782 & LC/MS-MS & 0.02 & 0.02 & $\mu \mathrm{g} / \mathrm{L}$ & LOQ & Lee and Strahan, 2003 (modified) \\
\hline 62850 & LC/MS-MS & 0.02 & 0.02 & $\mu \mathrm{g} / \mathrm{L}$ & LOQ & Lee and Strahan, 2003 (modified) \\
\hline 63781 & LC/MS-MS & 0.02 & 0.02 & $\mu \mathrm{g} / \mathrm{L}$ & LOQ & Lee and Strahan, 2003 (modified) \\
\hline 63777 & LC/MS-MS & 0.02 & 0.02 & $\mu \mathrm{g} / \mathrm{L}$ & LOQ & Lee and Strahan, 2003 (modified) \\
\hline 50009 & LC/MS-MS & 0.02 & 0.02 & $\mu \mathrm{g} / \mathrm{L}$ & LOQ & Lee and Strahan, 2003 (modified) \\
\hline 61031 & LC/MS-MS & 0.02 & 0.02 & $\mu \mathrm{g} / \mathrm{L}$ & LOQ & Lee and Strahan, 2003 (modified) \\
\hline 62848 & LC/MS-MS & 0.02 & 0.02 & $\mu \mathrm{g} / \mathrm{L}$ & LOQ & Lee and Strahan, 2003 (modified) \\
\hline 62849 & LC/MS-MS & 0.02 & 0.02 & $\mu \mathrm{g} / \mathrm{L}$ & LOQ & Lee and Strahan, 2003 (modified) \\
\hline 61588 & LC/MS-MS & 0.02 & 0.02 & $\mu \mathrm{g} / \mathrm{L}$ & LOQ & Lee and Strahan, 2003 (modified) \\
\hline 63779 & LC/MS-MS & 0.02 & 0.02 & $\mu \mathrm{g} / \mathrm{L}$ & LOQ & Lee and Strahan, 2003 (modified) \\
\hline 61952 & LC/MS-MS & 0.02 & 0.02 & $\mu \mathrm{g} / \mathrm{L}$ & LOQ & Lee and Strahan, 2003 (modified) \\
\hline 62483 & LC/MS-MS & 0.02 & 0.02 & $\mu \mathrm{g} / \mathrm{L}$ & LOQ & Lee and Strahan, 2003 (modified) \\
\hline 39415 & LC/MS-MS & 0.02 & 0.02 & $\mu \mathrm{g} / \mathrm{L}$ & LOQ & Lee and Strahan, 2003 (modified) \\
\hline 63780 & LC/MS-MS & 0.02 & 0.02 & $\mu \mathrm{g} / \mathrm{L}$ & LOQ & Lee and Strahan, 2003 (modified) \\
\hline
\end{tabular}


Table 2. Chemical compound information for analyses performed by various laboratories for the U.S. Geological Survey, Environmental Health Mission Area, Infrastructure Project, Tapwater Exposure Pilot Study, 2016-17.-Continued

[NWIS, National Water Information System; CAS, Chemical Abstract Services; y, year; NA, not available; EPA, U.S. Environmental Protection Agency; RED01, enzyme reduction-diazotization; GC, gas chromatograph; LC, liquid chromatography; ICP-MS, inductively coupled plasma-mass spectrometry; cICP-MS, cell inductively coupled plasma-mass spectrometry; HPLC/MS-MS, high performance liquid chromatography/tandem mass spectrometry; HCO3, bicarbonate; $\mu \mathrm{S} / \mathrm{cm}$, microsiemens per centimeter; $\mu \mathrm{g} / \mathrm{L}$, micrograms per liter; $\mathrm{mg} / \mathrm{L}$, milligrams per liter; ng/L, nanograms per liter; DAI-LC/MS-MS, direct aqueous injection-liquid chromatography/tandem mass spectrometry; ICP-OES, inductively coupled plasma-optical emission spectrometry; IC, ion chromatography; GCM66, ambient purgeable method (GC/MS); GM016, heat purgeable method (GC/MS); GC/MS-MS, gas chromatography/tandem mass spectrometry; LC/MS-MS, liquid chromatography-tandem mass spectrometry; ELISA, enzyme linked immunosorbent assay for algal toxins; MDL, method detection limit; MRL, minimum reporting level; IRL, interim reporting level; LOQ, limit of quantification; RLDQC, reporting limit by (DQCALC)]

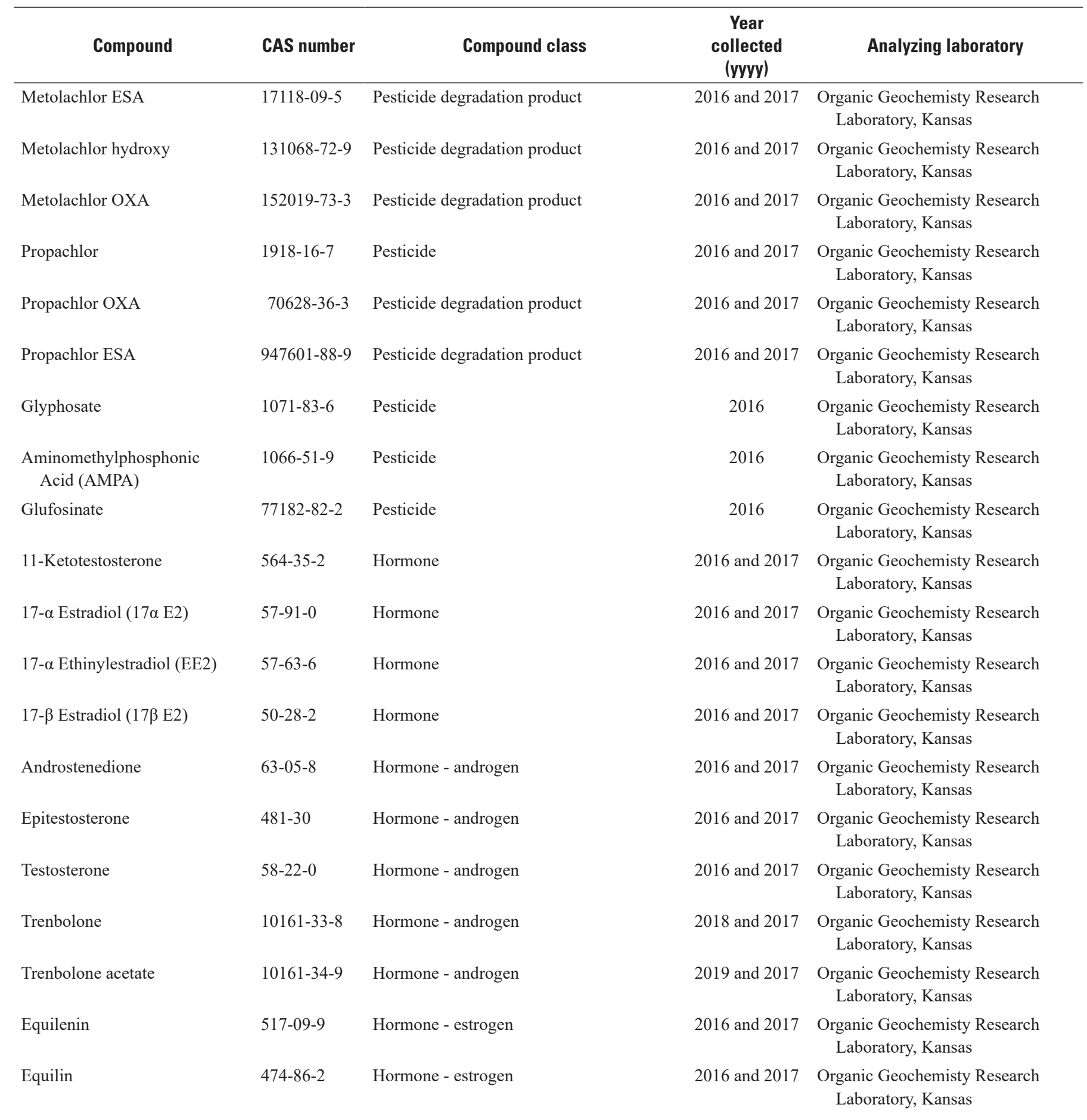


Table 2. $\quad 21$

Table 2. Chemical compound information for analyses performed by various laboratories for the U.S. Geological Survey, Environmental Health Mission Area, Infrastructure Project, Tapwater Exposure Pilot Study, 2016-17. —Continued

[NWIS, National Water Information System; CAS, Chemical Abstract Services; y, year; NA, not available; EPA, U.S. Environmental Protection Agency; RED01, enzyme reduction-diazotization; GC, gas chromatograph; LC, liquid chromatography; ICP-MS, inductively coupled plasma- mass spectrometry; cICP-MS, cell inductively coupled plasma-mass spectrometry; HPLC/MS-MS, high performance liquid chromatography-tandem mass spectrometry; HCO3, bicarbonate; $\mu \mathrm{S} / \mathrm{cm}$, microsiemens per centimeter; $\mu \mathrm{g} / \mathrm{L}$, micrograms per liter; $\mathrm{mg} / \mathrm{L}$, milligrams per liter; ng/L, nanograms per liter; DAI-LC/MS-MS, direct aqueous injection-liquid chromatography/tandem mass spectrometry; ICP-OES, inductively coupled plasma-optical emission spectrometry; IC, ion chromatography; GCM66, ambient purgeable method (GC/MS); GM016, heat purgeable method (GC/MS); GC/MS-MS, gas chromatography, tandem mass spectrometry; LC/MS-MS, liquid chromatography-tandem mass spectrometry; ELISA, enzyme linked immunosorbent assay for algal toxins; MDL, method detection limit; MRL, minimum reporting level; IRL, interim reporting level; LOQ, limit of quantification; RLDQC, reporting limit by (DQCALC)]

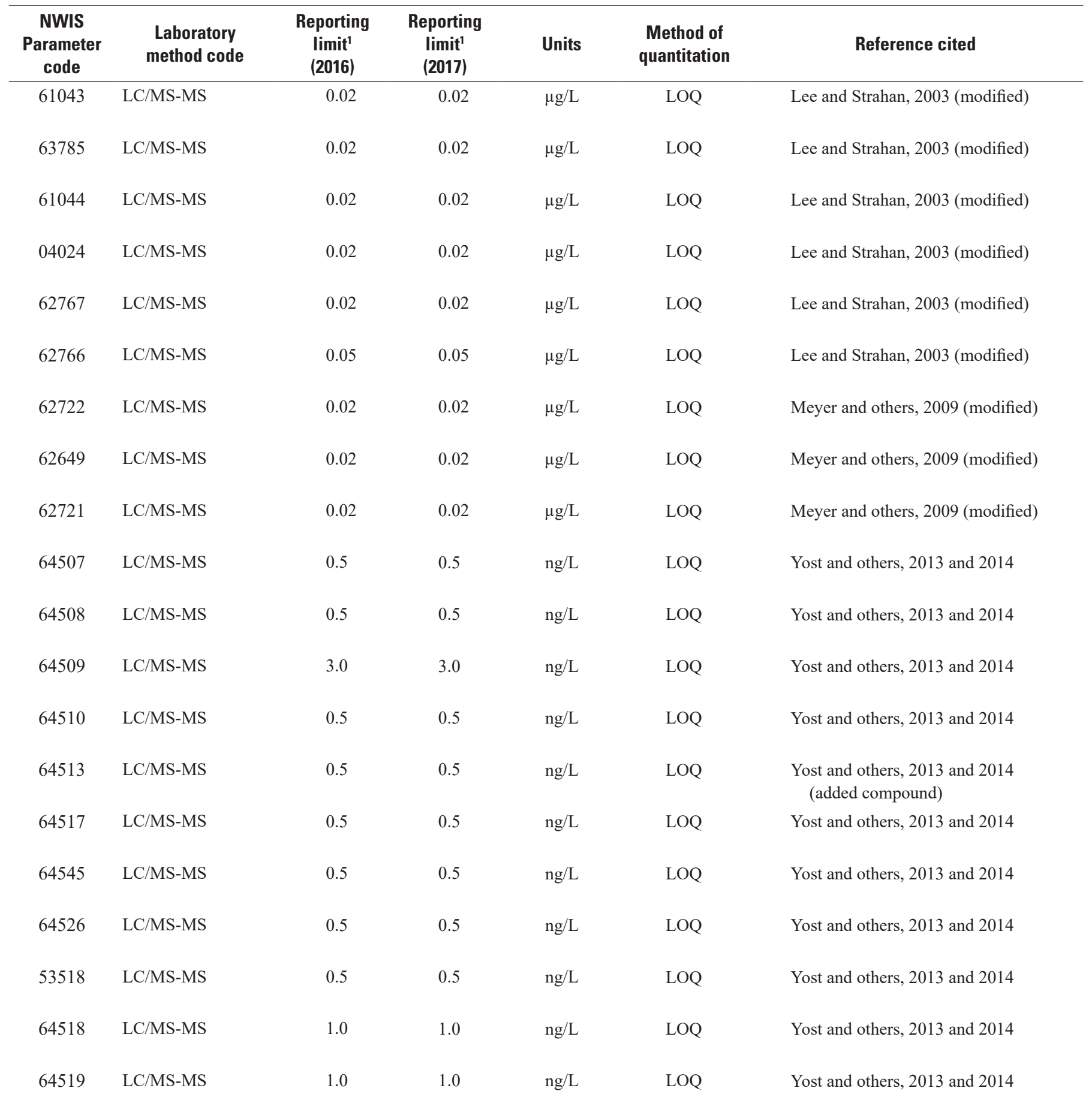


Table 2. Chemical compound information for analyses performed by various laboratories for the U.S. Geological Survey, Environmental Health Mission Area, Infrastructure Project, Tapwater Exposure Pilot Study, 2016-17.-Continued

[NWIS, National Water Information System; CAS, Chemical Abstract Services; y, year; NA, not available; EPA, U.S. Environmental Protection Agency; RED01, enzyme reduction-diazotization; GC, gas chromatograph; LC, liquid chromatography; ICP-MS, inductively coupled plasma-mass spectrometry; cICP-MS, cell inductively coupled plasma-mass spectrometry; HPLC/MS-MS, high performance liquid chromatography/tandem mass spectrometry; HCO3, bicarbonate; $\mu \mathrm{S} / \mathrm{cm}$, microsiemens per centimeter; $\mu \mathrm{g} / \mathrm{L}$, micrograms per liter; $\mathrm{mg} / \mathrm{L}$, milligrams per liter; ng/L, nanograms per liter; DAI-LC/MS-MS, direct aqueous injection-liquid chromatography/tandem mass spectrometry; ICP-OES, inductively coupled plasma-optical emission spectrometry; IC, ion chromatography; GCM66, ambient purgeable method (GC/MS); GM016, heat purgeable method (GC/MS); GC/MS-MS, gas chromatography/tandem mass spectrometry; LC/MS-MS, liquid chromatography-tandem mass spectrometry; ELISA, enzyme linked immunosorbent assay for algal toxins; MDL, method detection limit; MRL, minimum reporting level; IRL, interim reporting level; LOQ, limit of quantification; RLDQC, reporting limit by (DQCALC)]

\begin{tabular}{|c|c|c|}
\hline Compound & CAS number & Compound cl \\
\hline Estriol & $50-27-1$ & Hormone - estrogen \\
\hline Estrone & $53-16-7$ & Hormone - estrogen \\
\hline Trans-Diethylstilbestrol & $56-53-1$ & Hormone - estrogen \\
\hline Zearalenone & $17924-92-4$ & Hormone - mycoestrogen \\
\hline$\alpha$-zearalanol & $26538-44-3$ & Hormone - mycotoxin \\
\hline Beauvericin & $26048-05-5$ & Hormone - mycotoxin \\
\hline$\beta$-Zearalenol & $71030-11-0$ & Hormone - mycotoxin \\
\hline Deoxynivalenol & $51481-10-8$ & Hormone - mycotoxin \\
\hline Nivalenol & $23282-20-4$ & Hormone - mycotoxin \\
\hline Verrucarin A & 3148-09-02 & Hormone - mycotoxin \\
\hline Biochanin A & $491-80-5$ & Hormone - phytoestrogen \\
\hline Coumestrol & $479-13-0$ & Hormone - phytoestrogen \\
\hline Daidzein & $486-66-8$ & Hormone - phytoestrogen \\
\hline Equol & $531-95-3$ & Hormone - phytoestrogen \\
\hline Formonentin & $485-72-3$ & Hormone - phytoestrogen \\
\hline Genestein & $446-72-0$ & Hormone - phytoestrogen \\
\hline 19-Norethindrone & $62-88-4$ & Hormone - progestin \\
\hline Desogestrel & $54024-55-5$ & Hormone - progestin \\
\hline Drospirenone & $67392-87-4$ & Hormone - progestin \\
\hline Gestodene & $60282-87-3$ & Hormone - progestin \\
\hline
\end{tabular}

\begin{tabular}{c}
$\begin{array}{c}\text { Year } \\
\text { collected } \\
\text { (yyyy) }\end{array}$ Analyzing laboratory \\
\hline
\end{tabular}

2016 and 2017 Organic Geochemisty Research Laboratory, Kansas

2016 and 2017 Organic Geochemisty Research Laboratory, Kansas

2016 and 2017 Organic Geochemisty Research Laboratory, Kansas

2021 and 2017 Organic Geochemisty Research Laboratory, Kansas

2016 and 2017 Organic Geochemisty Research Laboratory, Kansas

2016 and 2017 Organic Geochemisty Research Laboratory, Kansas

2016 and 2017 Organic Geochemisty Research Laboratory, Kansas

2016 and 2017 Organic Geochemisty Research Laboratory, Kansas

2016 and 2017 Organic Geochemisty Research Laboratory, Kansas

2020 and 2017 Organic Geochemisty Research Laboratory, Kansas

2016 and 2017 Organic Geochemisty Research Laboratory, Kansas

2016 and 2017 Organic Geochemisty Research Laboratory, Kansas

2016 and 2017 Organic Geochemisty Research Laboratory, Kansas

2016 and 2017 Organic Geochemisty Research Laboratory, Kansas

2016 and 2017 Organic Geochemisty Research Laboratory, Kansas

2016 and 2017 Organic Geochemisty Research Laboratory, Kansas

2016 and 2017 Organic Geochemisty Research Laboratory, Kansas

2016 and 2017 Organic Geochemisty Research Laboratory, Kansas

2016 and 2017 Organic Geochemisty Research Laboratory, Kansas

2016 and 2017 Organic Geochemisty Research Laboratory, Kansas 
Table 2. Chemical compound information for analyses performed by various laboratories for the U.S. Geological Survey, Environmental Health Mission Area, Infrastructure Project, Tapwater Exposure Pilot Study, 2016-17. —Continued

[NWIS, National Water Information System; CAS, Chemical Abstract Services; y, year; NA, not available; EPA, U.S. Environmental Protection Agency; RED01, enzyme reduction-diazotization; GC, gas chromatograph; LC, liquid chromatography; ICP-MS, inductively coupled plasma- mass spectrometry; cICP-MS, cell inductively coupled plasma-mass spectrometry; HPLC/MS-MS, high performance liquid chromatography-tandem mass spectrometry; HCO3, bicarbonate; $\mu \mathrm{S} / \mathrm{cm}$, microsiemens per centimeter; $\mu \mathrm{g} / \mathrm{L}$, micrograms per liter; $\mathrm{mg} / \mathrm{L}$, milligrams per liter; ng/L, nanograms per liter; DAI-LC/MS-MS, direct aqueous injection-liquid chromatography/tandem mass spectrometry; ICP-OES, inductively coupled plasma-optical emission spectrometry; IC, ion chromatography; GCM66, ambient purgeable method (GC/MS); GM016, heat purgeable method (GC/MS); GC/MS-MS, gas chromatography, tandem mass spectrometry; LC/MS-MS, liquid chromatography-tandem mass spectrometry; ELISA, enzyme linked immunosorbent assay for algal toxins; MDL, method detection limit; MRL, minimum reporting level; IRL, interim reporting level; LOQ, limit of quantification; RLDQC, reporting limit by (DQCALC)]

\begin{tabular}{|c|c|c|c|c|c|c|}
\hline $\begin{array}{c}\text { NWIS } \\
\text { Parameter } \\
\text { code }\end{array}$ & $\begin{array}{l}\text { Laboratory } \\
\text { method code }\end{array}$ & $\begin{array}{c}\text { Reporting } \\
\text { limit' }^{1} \\
(2016)\end{array}$ & $\begin{array}{c}\text { Reporting } \\
\text { limit }^{1} \\
(2017)\end{array}$ & Units & $\begin{array}{l}\text { Method of } \\
\text { quantitation }\end{array}$ & Reference cited \\
\hline 64520 & LC/MS-MS & 0.5 & 0.5 & $\mathrm{ng} / \mathrm{L}$ & LOQ & Yost and others, 2013 and 2014 \\
\hline 64521 & LC/MS-MS & 0.5 & 0.5 & $\mathrm{ng} / \mathrm{L}$ & LOQ & Yost and others, 2013 and 2014 \\
\hline 53558 & LC/MS-MS & 0.5 & 0.5 & $\mathrm{ng} / \mathrm{L}$ & LOQ & $\begin{array}{l}\text { Yost and others, } 2013 \text { and } 2014 \\
\quad \text { (added compound) }\end{array}$ \\
\hline 53555 & LC/MS-MS & 0.5 & 0.5 & $\mathrm{ng} / \mathrm{L}$ & LOQ & $\begin{array}{l}\text { Yost and others, } 2013 \text { and } 2014 \\
\text { (added compound) }\end{array}$ \\
\hline 53551 & LC/MS-MS & 0.5 & 0.5 & $\mathrm{ng} / \mathrm{L}$ & LOQ & $\begin{array}{l}\text { Yost and others, } 2013 \text { and } 2014 \\
\text { (added compound) }\end{array}$ \\
\hline 53552 & LC/MS-MS & 1.0 & 1.0 & $\mathrm{ng} / \mathrm{L}$ & LOQ & $\begin{array}{l}\text { Yost and others, } 2013 \text { and } 2014 \\
\text { (added compound) }\end{array}$ \\
\hline 53553 & LC/MS-MS & 1.0 & 1.0 & $\mathrm{ng} / \mathrm{L}$ & LOQ & $\begin{array}{l}\text { Yost and others, } 2013 \text { and } 2014 \\
\text { (added compound) }\end{array}$ \\
\hline 53554 & LC/MS-MS & 0.5 & 0.5 & $\mathrm{ng} / \mathrm{L}$ & LOQ & $\begin{array}{l}\text { Yost and others, } 2013 \text { and } 2014 \\
\text { (added compound) }\end{array}$ \\
\hline 53545 & LC/MS-MS & 0.5 & 0.5 & $\mathrm{ng} / \mathrm{L}$ & LOQ & Yost and others, 2013 and 2014 \\
\hline 53546 & LC/MS-MS & 0.5 & 0.5 & $\mathrm{ng} / \mathrm{L}$ & LOQ & Yost and others, 2013 and 2014 \\
\hline 53543 & LC/MS-MS & 0.5 & 0.5 & $\mathrm{ng} / \mathrm{L}$ & LOQ & $\begin{array}{l}\text { Yost and others, } 2013 \text { and } 2014 \\
\text { (added compound) }\end{array}$ \\
\hline 53535 & LC/MS-MS & 1.0 & 1.0 & $\mathrm{ng} / \mathrm{L}$ & LOQ & $\begin{array}{l}\text { Yost and others, } 2013 \text { and } 2014 \\
\text { (added compound) }\end{array}$ \\
\hline 53536 & LC/MS-MS & 0.5 & 0.5 & $\mathrm{ng} / \mathrm{L}$ & LOQ & $\begin{array}{l}\text { Yost and others, } 2013 \text { and } 2014 \\
\text { (added compound) }\end{array}$ \\
\hline 53537 & LC/MS-MS & 0.5 & 0.5 & $\mathrm{ng} / \mathrm{L}$ & LOQ & $\begin{array}{l}\text { Yost and others, } 2013 \text { and } 2014 \\
\text { (added compound) }\end{array}$ \\
\hline
\end{tabular}


Table 2. Chemical compound information for analyses performed by various laboratories for the U.S. Geological Survey, Environmental Health Mission Area, Infrastructure Project, Tapwater Exposure Pilot Study, 2016-17.-Continued

[NWIS, National Water Information System; CAS, Chemical Abstract Services; y, year; NA, not available; EPA, U.S. Environmental Protection Agency; RED01, enzyme reduction-diazotization; GC, gas chromatograph; LC, liquid chromatography; ICP-MS, inductively coupled plasma-mass spectrometry; cICP-MS, cell inductively coupled plasma-mass spectrometry; HPLC/MS-MS, high performance liquid chromatography/tandem mass spectrometry; HCO3, bicarbonate; $\mu \mathrm{S} / \mathrm{cm}$, microsiemens per centimeter; $\mu \mathrm{g} / \mathrm{L}$, micrograms per liter; $\mathrm{mg} / \mathrm{L}$, milligrams per liter; ng/L, nanograms per liter; DAI-LC/MS-MS, direct aqueous injection-liquid chromatography/tandem mass spectrometry; ICP-OES, inductively coupled plasma-optical emission spectrometry; IC, ion chromatography; GCM66, ambient purgeable method (GC/MS); GM016, heat purgeable method (GC/MS); GC/MS-MS, gas chromatography/tandem mass spectrometry; LC/MS-MS, liquid chromatography-tandem mass spectrometry; ELISA, enzyme linked immunosorbent assay for algal toxins; MDL, method detection limit; MRL, minimum reporting level; IRL, interim reporting level; LOQ, limit of quantification; RLDQC, reporting limit by (DQCALC)]

\begin{tabular}{|c|c|c|c|c|}
\hline Compound & CAS number & Compound class & $\begin{array}{c}\text { Year } \\
\text { collected } \\
\text { (yyyy) }\end{array}$ & Analyzing laboratory \\
\hline Levonor-gestrel & $797-63-7$ & Hormone - progestin & 2016 and 2017 & $\begin{array}{l}\text { Organic Geochemisty Research } \\
\text { Laboratory, Kansas }\end{array}$ \\
\hline Medroxy-progesterone & $520-85-4$ & Hormone - progestin & 2016 and 2017 & $\begin{array}{l}\text { Organic Geochemisty Research } \\
\text { Laboratory, Kansas }\end{array}$ \\
\hline Nestorone & $7759-35-5$ & Hormone - progestin & 2016 and 2017 & $\begin{array}{l}\text { Organic Geochemisty Research } \\
\text { Laboratory, Kansas }\end{array}$ \\
\hline Nomegestrol acetate & $58652-20-3$ & Hormone - progestin & 2016 and 2017 & $\begin{array}{l}\text { Organic Geochemisty Research } \\
\text { Laboratory, Kansas }\end{array}$ \\
\hline Norgestimate & $35189-28-7$ & Hormone - progestin & 2016 and 2017 & $\begin{array}{l}\text { Organic Geochemisty Research } \\
\text { Laboratory, Kansas }\end{array}$ \\
\hline $17 \beta$-estradiol-17-glucuronide & $1806-98-0$ & Hormone conjugate & 2016 and 2017 & $\begin{array}{l}\text { Organic Geochemisty Research } \\
\text { Laboratory, Kansas }\end{array}$ \\
\hline $17 \beta$-estradiol-17-sulfate & $3233-69-0$ & Hormone conjugate & 2016 and 2017 & $\begin{array}{l}\text { Organic Geochemisty Research } \\
\text { Laboratory, Kansas }\end{array}$ \\
\hline $17 \beta$-estradiol-3-sulfate & $481-96-9$ & Hormone conjugate & 2016 and 2017 & $\begin{array}{l}\text { Organic Geochemisty Research } \\
\text { Laboratory, Kansas }\end{array}$ \\
\hline Androsterone sulfate & $2479-86-9$ & Hormone conjugate & 2016 and 2017 & $\begin{array}{l}\text { Organic Geochemisty Research } \\
\text { Laboratory, Kansas }\end{array}$ \\
\hline Androsterone-glucuronide & $1852-43-3$ & Hormone conjugate & 2016 and 2017 & $\begin{array}{l}\text { Organic Geochemisty Research } \\
\text { Laboratory, Kansas }\end{array}$ \\
\hline Estriol-3-glucuronide & $2479-91-6$ & Hormone conjugate & 2016 and 2017 & $\begin{array}{l}\text { Organic Geochemisty Research } \\
\text { Laboratory, Kansas }\end{array}$ \\
\hline Estriol-3-sulfate & $481-95-8$ & Hormone conjugate & 2016 and 2017 & $\begin{array}{l}\text { Organic Geochemisty Research } \\
\text { Laboratory, Kansas }\end{array}$ \\
\hline Estrone glucuronide & $2479-90-5$ & Hormone conjugate & 2016 and 2017 & $\begin{array}{l}\text { Organic Geochemisty Research } \\
\text { Laboratory, Kansas }\end{array}$ \\
\hline Estrone-3-sulfate & $481-97-0$ & Hormone conjugate & 2016 and 2017 & $\begin{array}{l}\text { Organic Geochemisty Research } \\
\text { Laboratory, Kansas }\end{array}$ \\
\hline
\end{tabular}


Table 2. Chemical compound information for analyses performed by various laboratories for the U.S. Geological Survey, Environmental Health Mission Area, Infrastructure Project, Tapwater Exposure Pilot Study, 2016-17. —Continued

[NWIS, National Water Information System; CAS, Chemical Abstract Services; y, year; NA, not available; EPA, U.S. Environmental Protection Agency; RED01, enzyme reduction-diazotization; GC, gas chromatograph; LC, liquid chromatography; ICP-MS, inductively coupled plasma- mass spectrometry; cICP-MS, cell inductively coupled plasma-mass spectrometry; HPLC/MS-MS, high performance liquid chromatography-tandem mass spectrometry; HCO3, bicarbonate; $\mu \mathrm{S} / \mathrm{cm}$, microsiemens per centimeter; $\mu \mathrm{g} / \mathrm{L}$, micrograms per liter; $\mathrm{mg} / \mathrm{L}$, milligrams per liter; ng/L, nanograms per liter; DAI-LC/MS-MS, direct aqueous injection-liquid chromatography/tandem mass spectrometry; ICP-OES, inductively coupled plasma-optical emission spectrometry; IC, ion chromatography; GCM66, ambient purgeable method (GC/MS); GM016, heat purgeable method (GC/MS); GC/MS-MS, gas chromatography, tandem mass spectrometry; LC/MS-MS, liquid chromatography-tandem mass spectrometry; ELISA, enzyme linked immunosorbent assay for algal toxins; MDL, method detection limit; MRL, minimum reporting level; IRL, interim reporting level; LOQ, limit of quantification; RLDQC, reporting limit by (DQCALC)]

\begin{tabular}{|c|c|c|c|c|c|c|}
\hline $\begin{array}{c}\text { NWIS } \\
\text { Parameter } \\
\text { code }\end{array}$ & $\begin{array}{l}\text { Laboratory } \\
\text { method code }\end{array}$ & $\begin{array}{c}\text { Reporting } \\
\text { limit }^{1} \\
(2016)\end{array}$ & $\begin{array}{c}\text { Reporting } \\
\text { limit }^{1} \\
(2017)\end{array}$ & Units & $\begin{array}{l}\text { Method of } \\
\text { quantitation }\end{array}$ & Reference cited \\
\hline 53538 & LC/MS-MS & 0.5 & 0.5 & $\mathrm{ng} / \mathrm{L}$ & LOQ & $\begin{array}{l}\text { Yost and others, } 2013 \text { and } 2014 \\
\text { (added compound) }\end{array}$ \\
\hline 53539 & LC/MS-MS & 0.5 & 0.5 & $\mathrm{ng} / \mathrm{L}$ & LOQ & $\begin{array}{l}\text { Yost and others, } 2013 \text { and } 2014 \\
\text { (added compound) }\end{array}$ \\
\hline 53541 & LC/MS-MS & 0.5 & 0.5 & $\mathrm{ng} / \mathrm{L}$ & LOQ & $\begin{array}{l}\text { Yost and others, } 2013 \text { and } 2014 \\
\text { (added compound) }\end{array}$ \\
\hline 53542 & LC/MS-MS & 0.5 & 0.5 & $\mathrm{ng} / \mathrm{L}$ & LOQ & $\begin{array}{l}\text { Yost and others, } 2013 \text { and } 2014 \\
\text { (added compound) }\end{array}$ \\
\hline 53544 & LC/MS-MS & 0.5 & 0.5 & $\mathrm{ng} / \mathrm{L}$ & LOQ & $\begin{array}{l}\text { Yost and others, } 2013 \text { and } 2014 \\
\text { (added compound) }\end{array}$ \\
\hline 53521 & LC/MS-MS & 0.5 & 0.5 & $\mathrm{ng} / \mathrm{L}$ & LOQ & Yost and others, 2013 and 2014 \\
\hline 53529 & LC/MS-MS & 0.5 & 0.5 & $\mathrm{ng} / \mathrm{L}$ & LOQ & Yost and others, 2013 and 2014 \\
\hline 53528 & LC/MS-MS & 0.5 & 0.5 & $\mathrm{ng} / \mathrm{L}$ & LOQ & Yost and others, 2013 and 2014 \\
\hline 53525 & LC/MS-MS & 0.5 & 0.5 & $\mathrm{ng} / \mathrm{L}$ & LOQ & Yost and others, 2013 and 2014 \\
\hline 53519 & LC/MS-MS & 0.5 & 0.5 & $\mathrm{ng} / \mathrm{L}$ & LOQ & Yost and others, 2013 and 2014 \\
\hline 53522 & LC/MS-MS & 0.5 & 0.5 & $\mathrm{ng} / \mathrm{L}$ & LOQ & Yost and others, 2013 and 2014 \\
\hline 53530 & LC/MS-MS & 0.5 & 0.5 & $\mathrm{ng} / \mathrm{L}$ & LOQ & Yost and others, 2013 and 2014 \\
\hline 53523 & LC/MS-MS & 0.5 & 0.5 & $\mathrm{ng} / \mathrm{L}$ & LOQ & Yost and others, 2013 and 2014 \\
\hline 53532 & LC/MS-MS & 0.5 & 0.5 & $\mathrm{ng} / \mathrm{L}$ & LOQ & Yost and others, 2013 and 2014 \\
\hline
\end{tabular}


Table 2. Chemical compound information for analyses performed by various laboratories for the U.S. Geological Survey, Environmental Health Mission Area, Infrastructure Project, Tapwater Exposure Pilot Study, 2016-17.-Continued

[NWIS, National Water Information System; CAS, Chemical Abstract Services; y, year; NA, not available; EPA, U.S. Environmental Protection Agency; RED01, enzyme reduction-diazotization; GC, gas chromatograph; LC, liquid chromatography; ICP-MS, inductively coupled plasma-mass spectrometry; cICP-MS, cell inductively coupled plasma-mass spectrometry; HPLC/MS-MS, high performance liquid chromatography/tandem mass spectrometry; HCO3, bicarbonate; $\mu \mathrm{S} / \mathrm{cm}$, microsiemens per centimeter; $\mu \mathrm{g} / \mathrm{L}$, micrograms per liter; $\mathrm{mg} / \mathrm{L}$, milligrams per liter; ng/L, nanograms per liter; DAI-LC/MS-MS, direct aqueous injection-liquid chromatography/tandem mass spectrometry; ICP-OES, inductively coupled plasma-optical emission spectrometry; IC, ion chromatography; GCM66, ambient purgeable method (GC/MS); GM016, heat purgeable method (GC/MS); GC/MS-MS, gas chromatography/tandem mass spectrometry; LC/MS-MS, liquid chromatography-tandem mass spectrometry; ELISA, enzyme linked immunosorbent assay for algal toxins; MDL, method detection limit; MRL, minimum reporting level; IRL, interim reporting level; LOQ, limit of quantification; RLDQC, reporting limit by (DQCALC)]

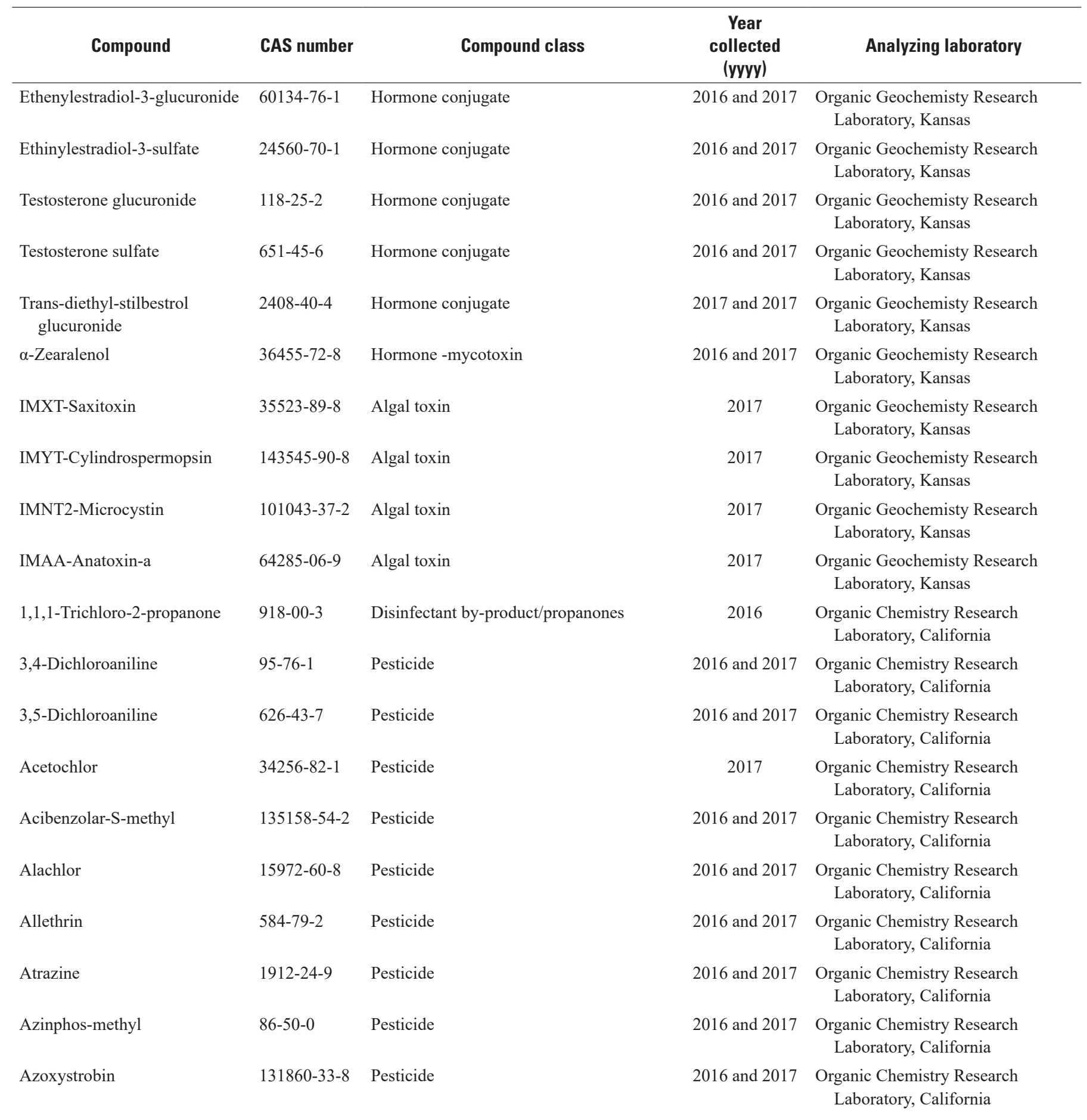


Table 2. Chemical compound information for analyses performed by various laboratories for the U.S. Geological Survey, Environmental Health Mission Area, Infrastructure Project, Tapwater Exposure Pilot Study, 2016-17. —Continued

[NWIS, National Water Information System; CAS, Chemical Abstract Services; y, year; NA, not available; EPA, U.S. Environmental Protection Agency; RED01, enzyme reduction-diazotization; GC, gas chromatograph; LC, liquid chromatography; ICP-MS, inductively coupled plasma- mass spectrometry; cICP-MS, cell inductively coupled plasma-mass spectrometry; HPLC/MS-MS, high performance liquid chromatography-tandem mass spectrometry; HCO3, bicarbonate; $\mu \mathrm{S} / \mathrm{cm}$, microsiemens per centimeter; $\mu \mathrm{g} / \mathrm{L}$, micrograms per liter; $\mathrm{mg} / \mathrm{L}$, milligrams per liter; ng/L, nanograms per liter; DAI-LC/MS-MS, direct aqueous injection-liquid chromatography/tandem mass spectrometry; ICP-OES, inductively coupled plasma-optical emission spectrometry; IC, ion chromatography; GCM66, ambient purgeable method (GC/MS); GM016, heat purgeable method (GC/MS); GC/MS-MS, gas chromatography, tandem mass spectrometry; LC/MS-MS, liquid chromatography-tandem mass spectrometry; ELISA, enzyme linked immunosorbent assay for algal toxins; MDL, method detection limit; MRL, minimum reporting level; IRL, interim reporting level; LOQ, limit of quantification; RLDQC, reporting limit by (DQCALC)]

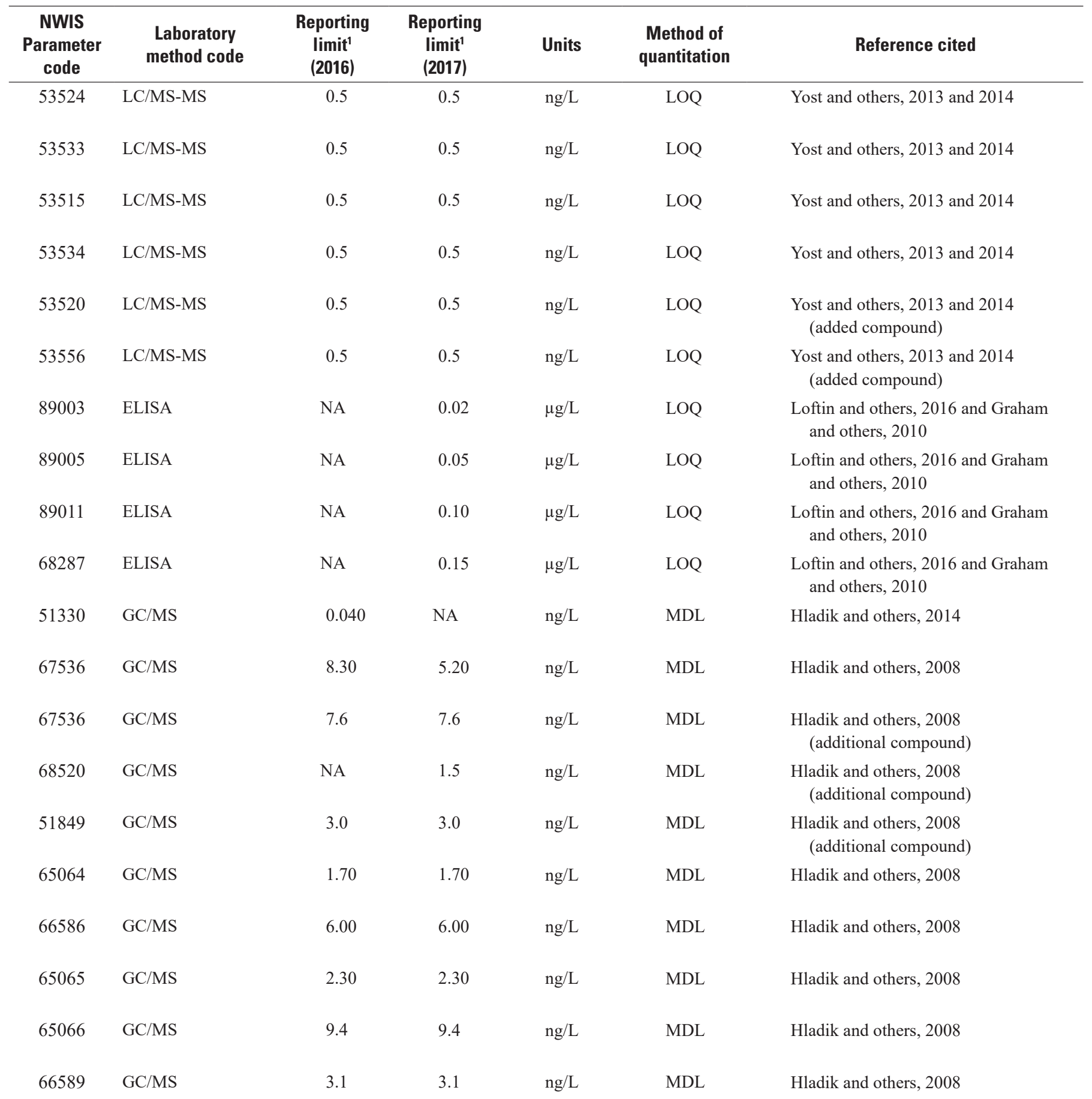


Table 2. Chemical compound information for analyses performed by various laboratories for the U.S. Geological Survey, Environmental Health Mission Area, Infrastructure Project, Tapwater Exposure Pilot Study, 2016-17.-Continued

[NWIS, National Water Information System; CAS, Chemical Abstract Services; y, year; NA, not available; EPA, U.S. Environmental Protection Agency; RED01, enzyme reduction-diazotization; GC, gas chromatograph; LC, liquid chromatography; ICP-MS, inductively coupled plasma-mass spectrometry; cICP-MS, cell inductively coupled plasma-mass spectrometry; HPLC/MS-MS, high performance liquid chromatography/tandem mass spectrometry; HCO3, bicarbonate; $\mu \mathrm{S} / \mathrm{cm}$, microsiemens per centimeter; $\mu \mathrm{g} / \mathrm{L}$, micrograms per liter; $\mathrm{mg} / \mathrm{L}$, milligrams per liter; ng/L, nanograms per liter; DAI-LC/MS-MS, direct aqueous injection-liquid chromatography/tandem mass spectrometry; ICP-OES, inductively coupled plasma-optical emission spectrometry; IC, ion chromatography; GCM66, ambient purgeable method (GC/MS); GM016, heat purgeable method (GC/MS); GC/MS-MS, gas chromatography/tandem mass spectrometry; LC/MS-MS, liquid chromatography-tandem mass spectrometry; ELISA, enzyme linked immunosorbent assay for algal toxins; MDL, method detection limit; MRL, minimum reporting level; IRL, interim reporting level; LOQ, limit of quantification; RLDQC, reporting limit by (DQCALC)]

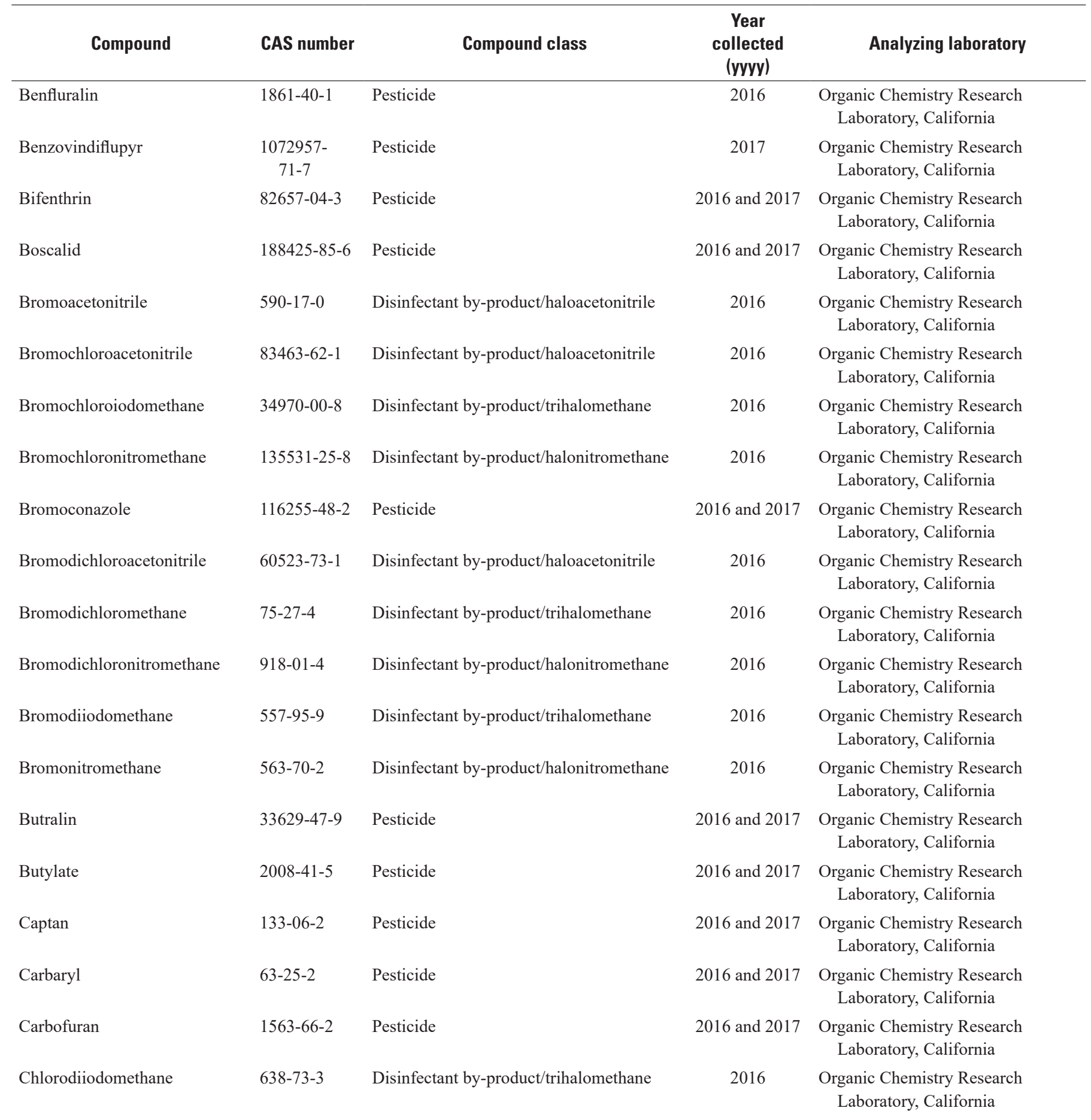


Table 2. Chemical compound information for analyses performed by various laboratories for the U.S. Geological Survey, Environmental Health Mission Area, Infrastructure Project, Tapwater Exposure Pilot Study, 2016-17. —Continued

[NWIS, National Water Information System; CAS, Chemical Abstract Services; y, year; NA, not available; EPA, U.S. Environmental Protection Agency; RED01, enzyme reduction-diazotization; GC, gas chromatograph; LC, liquid chromatography; ICP-MS, inductively coupled plasma- mass spectrometry; cICP-MS, cell inductively coupled plasma-mass spectrometry; HPLC/MS-MS, high performance liquid chromatography-tandem mass spectrometry; HCO3, bicarbonate; $\mu \mathrm{S} / \mathrm{cm}$, microsiemens per centimeter; $\mu \mathrm{g} / \mathrm{L}$, micrograms per liter; $\mathrm{mg} / \mathrm{L}$, milligrams per liter; ng/L, nanograms per liter; DAI-LC/MS-MS, direct aqueous injection-liquid chromatography/tandem mass spectrometry; ICP-OES, inductively coupled plasma-optical emission spectrometry; IC, ion chromatography; GCM66, ambient purgeable method (GC/MS); GM016, heat purgeable method (GC/MS); GC/MS-MS, gas chromatography, tandem mass spectrometry; LC/MS-MS, liquid chromatography-tandem mass spectrometry; ELISA, enzyme linked immunosorbent assay for algal toxins; MDL, method detection limit; MRL, minimum reporting level; IRL, interim reporting level; LOQ, limit of quantification; RLDQC, reporting limit by (DQCALC)]

\begin{tabular}{|c|c|c|c|c|c|c|}
\hline $\begin{array}{c}\text { NWIS } \\
\text { Parameter } \\
\text { code }\end{array}$ & $\begin{array}{l}\text { Laboratory } \\
\text { method code }\end{array}$ & $\begin{array}{c}\text { Reporting } \\
\text { limit }^{1} \\
(2016)\end{array}$ & $\begin{array}{c}\text { Reporting } \\
\text { limit }^{1} \\
(2017)\end{array}$ & Units & $\begin{array}{c}\text { Method of } \\
\text { quantitation }\end{array}$ & Reference cited \\
\hline 51643 & GC/MS & 2.0 & NA & $\mathrm{ng} / \mathrm{L}$ & MDL & $\begin{array}{l}\text { Hladik and others, } 2008 \\
\quad \text { (additional compound) }\end{array}$ \\
\hline 52652 & GC/MS & NA & 3.4 & $\mathrm{ng} / \mathrm{L}$ & MDL & $\begin{array}{l}\text { Hladik and others, } 2008 \\
\quad \text { (additional compound) }\end{array}$ \\
\hline 67550 & $\mathrm{GC} / \mathrm{MS}$ & 2.80 & 2.80 & $\mathrm{ng} / \mathrm{L}$ & MDL & Hladik and others, 2008 \\
\hline 51320 & GC/MS & 0.200 & NA & $\mathrm{ng} / \mathrm{L}$ & MDL & Hladik and others, 2014 \\
\hline 51321 & GC/MS & 0.200 & NA & $\mathrm{ng} / \mathrm{L}$ & MDL & Hladik and others, 2014 \\
\hline 51313 & $\mathrm{GC} / \mathrm{MS}$ & 0.020 & NA & $\mathrm{ng} / \mathrm{L}$ & MDL & Hladik and others, 2014 \\
\hline 68315 & GC/MS & 3.20 & 3.20 & $\mathrm{ng} / \mathrm{L}$ & MDL & Hladik and others, 2008 \\
\hline 51322 & GC/MS & 0.040 & NA & $\mathrm{ng} / \mathrm{L}$ & MDL & Hladik and others, 2014 \\
\hline 34328 & GC/MS & 0.100 & NA & $\mathrm{ng} / \mathrm{L}$ & MDL & Hladik and others, 2014 \\
\hline 51314 & $\mathrm{GC} / \mathrm{MS}$ & 0.020 & NA & $\mathrm{ng} / \mathrm{L}$ & MDL & Hladik and others, 2014 \\
\hline 68322 & GC/MS & 10.2 & 10.2 & $\mathrm{ng} / \mathrm{L}$ & MDL & Hladik and others, 2008 \\
\hline 65069 & $\mathrm{GC} / \mathrm{MS}$ & 6.50 & 6.50 & $\mathrm{ng} / \mathrm{L}$ & MDL & Hladik and others, 2008 \\
\hline 65070 & GC/MS & 3.10 & 3.10 & $\mathrm{ng} / \mathrm{L}$ & MDL & Hladik and others, 2008 \\
\hline 51309 & GC/MS & 0.020 & NA & $\mathrm{ng} / \mathrm{L}$ & MDL & Hladik and others, 2014 \\
\hline
\end{tabular}


Table 2. Chemical compound information for analyses performed by various laboratories for the U.S. Geological Survey, Environmental Health Mission Area, Infrastructure Project, Tapwater Exposure Pilot Study, 2016-17._Continued

[NWIS, National Water Information System; CAS, Chemical Abstract Services; y, year; NA, not available; EPA, U.S. Environmental Protection Agency; RED01, enzyme reduction-diazotization; GC, gas chromatograph; LC, liquid chromatography; ICP-MS, inductively coupled plasma-mass spectrometry; cICP-MS, cell inductively coupled plasma-mass spectrometry; HPLC/MS-MS, high performance liquid chromatography/tandem mass spectrometry; HCO3, bicarbonate; $\mu \mathrm{S} / \mathrm{cm}$, microsiemens per centimeter; $\mu \mathrm{g} / \mathrm{L}$, micrograms per liter; $\mathrm{mg} / \mathrm{L}$, milligrams per liter; ng/L, nanograms per liter; DAI-LC/MS-MS, direct aqueous injection-liquid chromatography/tandem mass spectrometry; ICP-OES, inductively coupled plasma-optical emission spectrometry; IC, ion chromatography; GCM66, ambient purgeable method (GC/MS); GM016, heat purgeable method (GC/MS); GC/MS-MS, gas chromatography/tandem mass spectrometry; LC/MS-MS, liquid chromatography-tandem mass spectrometry; ELISA, enzyme linked immunosorbent assay for algal toxins; MDL, method detection limit; MRL, minimum reporting level; IRL, interim reporting level; LOQ, limit of quantification; RLDQC, reporting limit by (DQCALC)]

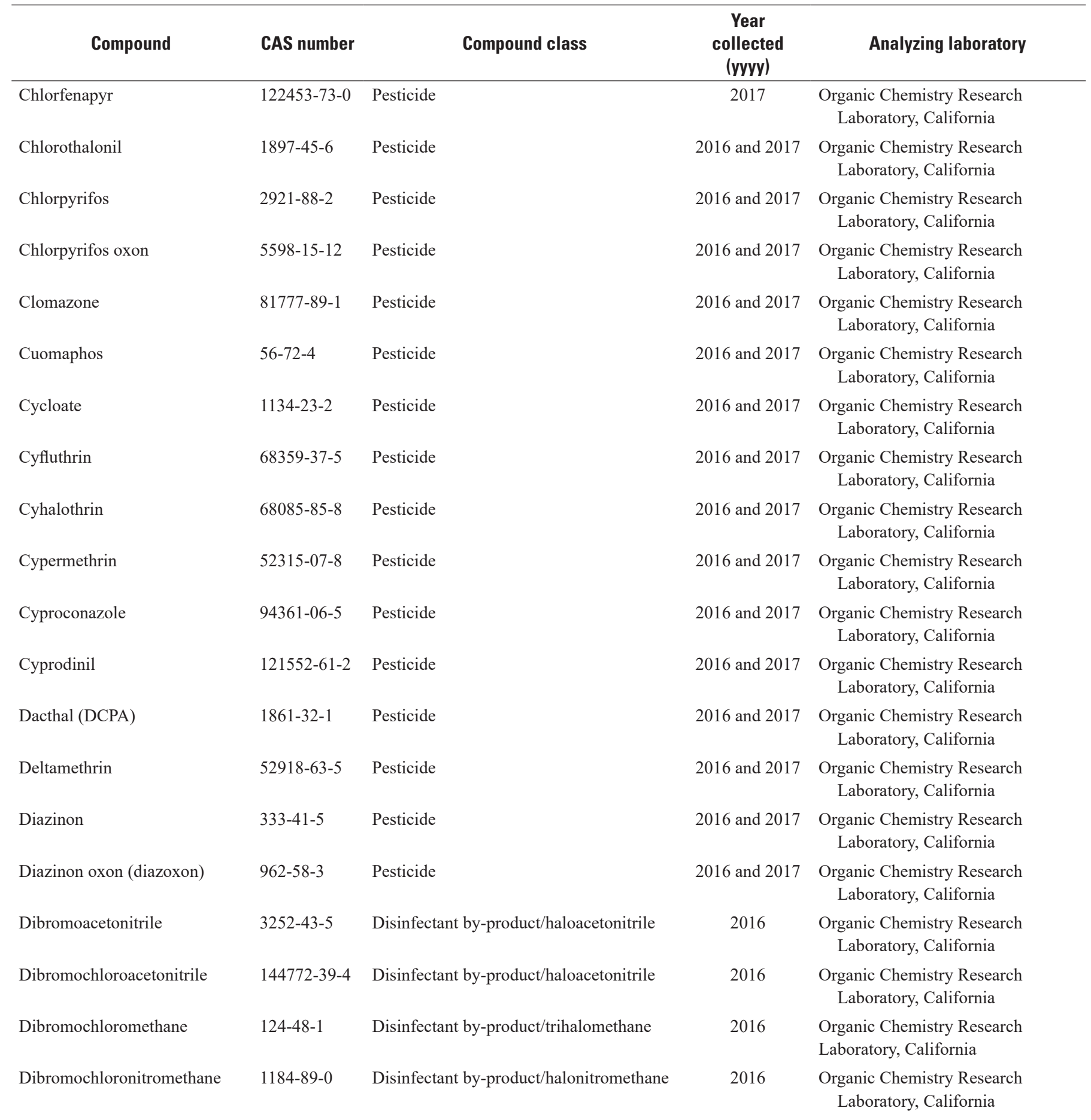


Table 2. $\quad 31$

Table 2. Chemical compound information for analyses performed by various laboratories for the U.S. Geological Survey, Environmental Health Mission Area, Infrastructure Project, Tapwater Exposure Pilot Study, 2016-17. —Continued

[NWIS, National Water Information System; CAS, Chemical Abstract Services; y, year; NA, not available; EPA, U.S. Environmental Protection Agency; RED01, enzyme reduction-diazotization; GC, gas chromatograph; LC, liquid chromatography; ICP-MS, inductively coupled plasma- mass spectrometry; cICP-MS, cell inductively coupled plasma-mass spectrometry; HPLC/MS-MS, high performance liquid chromatography-tandem mass spectrometry; HCO3, bicarbonate; $\mu \mathrm{S} / \mathrm{cm}$, microsiemens per centimeter; $\mu \mathrm{g} / \mathrm{L}$, micrograms per liter; $\mathrm{mg} / \mathrm{L}$, milligrams per liter; ng/L, nanograms per liter; DAI-LC/MS-MS, direct aqueous injection-liquid chromatography/tandem mass spectrometry; ICP-OES, inductively coupled plasma-optical emission spectrometry; IC, ion chromatography; GCM66, ambient purgeable method (GC/MS); GM016, heat purgeable method (GC/MS); GC/MS-MS, gas chromatography, tandem mass spectrometry; LC/MS-MS, liquid chromatography-tandem mass spectrometry; ELISA, enzyme linked immunosorbent assay for algal toxins; MDL, method detection limit; MRL, minimum reporting level; IRL, interim reporting level; LOQ, limit of quantification; RLDQC, reporting limit by (DQCALC)]

\begin{tabular}{|c|c|c|c|c|c|c|}
\hline $\begin{array}{c}\text { NWIS } \\
\text { Parameter } \\
\text { code }\end{array}$ & $\begin{array}{l}\text { Laboratory } \\
\text { method code }\end{array}$ & $\begin{array}{c}\text { Reporting } \\
\text { limit }^{1} \\
(2016)\end{array}$ & $\begin{array}{c}\text { Reporting } \\
\text { limit }^{1} \\
(2017)\end{array}$ & Units & $\begin{array}{c}\text { Method of } \\
\text { quantitation }\end{array}$ & Reference cited \\
\hline NA & GC/MS & NA & 3.30 & $\mathrm{ng} / \mathrm{L}$ & MDL & $\begin{array}{l}\text { Hladik and others, } 2008 \\
\quad \text { (additional compound) }\end{array}$ \\
\hline 65071 & GC/MS & 4.1 & 4.1 & $\mathrm{ng} / \mathrm{L}$ & MDL & Hladik and others, 2008 \\
\hline 68216 & GC/MS & 5.0 & 5.0 & $\mathrm{ng} / \mathrm{L}$ & MDL & $\begin{array}{l}\text { Hladik and others, } 2008 \\
\quad \text { (additional compound) }\end{array}$ \\
\hline 67562 & GC/MS & 2.50 & 2.50 & $\mathrm{ng} / \mathrm{L}$ & MDL & Hladik and others, 2008 \\
\hline 51836 & GC/MS & 3.1 & 3.1 & $\mathrm{ng} / \mathrm{L}$ & MDL & $\begin{array}{l}\text { Hladik and others, } 2008 \\
\quad \text { (additional compound) }\end{array}$ \\
\hline 65074 & $\mathrm{GC} / \mathrm{MS}$ & 5.20 & 5.20 & $\mathrm{ng} / \mathrm{L}$ & MDL & Hladik and others, 2008 \\
\hline 68354 & GC/MS & 2.00 & 2.00 & $\mathrm{ng} / \mathrm{L}$ & MDL & Hladik and others, 2008 \\
\hline 65075 & GC/MS & 5.60 & 5.60 & $\mathrm{ng} / \mathrm{L}$ & MDL & Hladik and others, 2008 \\
\hline 66593 & $\mathrm{GC} / \mathrm{MS}$ & 4.7 & 4.7 & $\mathrm{ng} / \mathrm{L}$ & MDL & Hladik and others, 2008 \\
\hline 67574 & $\mathrm{GC} / \mathrm{MS}$ & 7.40 & 7.40 & $\mathrm{ng} / \mathrm{L}$ & MDL & Hladik and others, 2008 \\
\hline 51323 & $\mathrm{GC} / \mathrm{MS}$ & 0.020 & NA & $\mathrm{ng} / \mathrm{L}$ & MDL & Hladik and others, 2014 \\
\hline 51324 & $\mathrm{GC} / \mathrm{MS}$ & 0.020 & NA & $\mathrm{ng} / \mathrm{L}$ & MDL & Hladik and others, 2014 \\
\hline 34307 & $\mathrm{GC} / \mathrm{MS}$ & 0.020 & NA & $\mathrm{ng} / \mathrm{L}$ & MDL & Hladik and others, 2014 \\
\hline 51316 & GC/MS & 0.100 & NA & $\mathrm{ng} / \mathrm{L}$ & MDL & Hladik and others, 2014 \\
\hline
\end{tabular}


Table 2. Chemical compound information for analyses performed by various laboratories for the U.S. Geological Survey, Environmental Health Mission Area, Infrastructure Project, Tapwater Exposure Pilot Study, 2016-17.-Continued

[NWIS, National Water Information System; CAS, Chemical Abstract Services; y, year; NA, not available; EPA, U.S. Environmental Protection Agency; RED01, enzyme reduction-diazotization; GC, gas chromatograph; LC, liquid chromatography; ICP-MS, inductively coupled plasma-mass spectrometry; cICP-MS, cell inductively coupled plasma-mass spectrometry; HPLC/MS-MS, high performance liquid chromatography/tandem mass spectrometry; HCO3, bicarbonate; $\mu \mathrm{S} / \mathrm{cm}$, microsiemens per centimeter; $\mu \mathrm{g} / \mathrm{L}$, micrograms per liter; $\mathrm{mg} / \mathrm{L}$, milligrams per liter; ng/L, nanograms per liter; DAI-LC/MS-MS, direct aqueous injection-liquid chromatography/tandem mass spectrometry; ICP-OES, inductively coupled plasma-optical emission spectrometry; IC, ion chromatography; GCM66, ambient purgeable method (GC/MS); GM016, heat purgeable method (GC/MS); GC/MS-MS, gas chromatography/tandem mass spectrometry; LC/MS-MS, liquid chromatography-tandem mass spectrometry; ELISA, enzyme linked immunosorbent assay for algal toxins; MDL, method detection limit; MRL, minimum reporting level; IRL, interim reporting level; LOQ, limit of quantification; RLDQC, reporting limit by (DQCALC)]

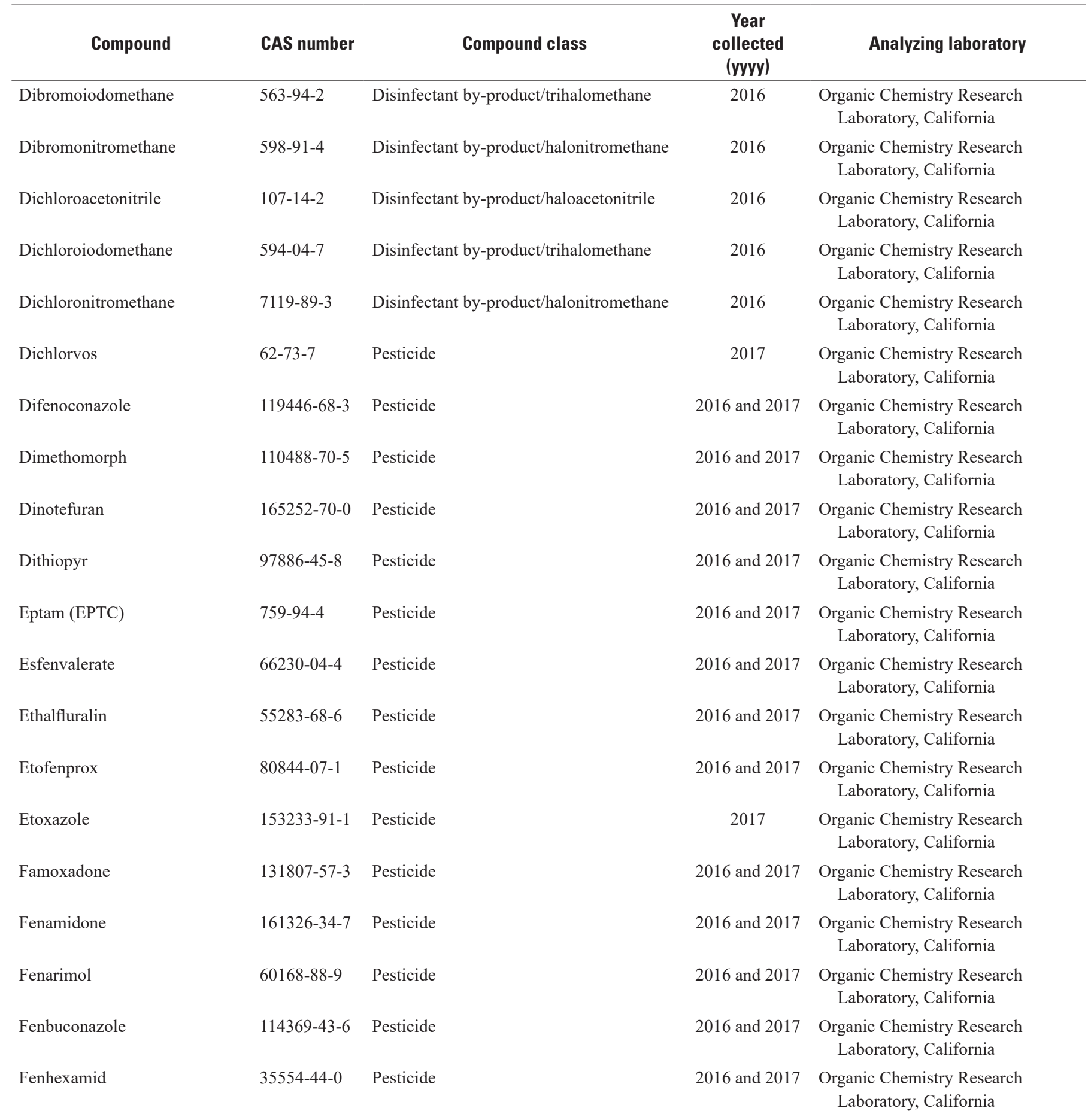


Table 2. $\quad 33$

Table 2. Chemical compound information for analyses performed by various laboratories for the U.S. Geological Survey, Environmental Health Mission Area, Infrastructure Project, Tapwater Exposure Pilot Study, 2016-17. —Continued

[NWIS, National Water Information System; CAS, Chemical Abstract Services; y, year; NA, not available; EPA, U.S. Environmental Protection Agency; RED01, enzyme reduction-diazotization; GC, gas chromatograph; LC, liquid chromatography; ICP-MS, inductively coupled plasma- mass spectrometry; cICP-MS, cell inductively coupled plasma-mass spectrometry; HPLC/MS-MS, high performance liquid chromatography-tandem mass spectrometry; HCO3, bicarbonate; $\mu \mathrm{S} / \mathrm{cm}$, microsiemens per centimeter; $\mu \mathrm{g} / \mathrm{L}$, micrograms per liter; $\mathrm{mg} / \mathrm{L}$, milligrams per liter; ng/L, nanograms per liter; DAI-LC/MS-MS, direct aqueous injection-liquid chromatography/tandem mass spectrometry; ICP-OES, inductively coupled plasma-optical emission spectrometry; IC, ion chromatography; GCM66, ambient purgeable method (GC/MS); GM016, heat purgeable method (GC/MS); GC/MS-MS, gas chromatography, tandem mass spectrometry; LC/MS-MS, liquid chromatography-tandem mass spectrometry; ELISA, enzyme linked immunosorbent assay for algal toxins; MDL, method detection limit; MRL, minimum reporting level; IRL, interim reporting level; LOQ, limit of quantification; RLDQC, reporting limit by (DQCALC)]

\begin{tabular}{|c|c|c|c|c|c|c|}
\hline $\begin{array}{c}\text { NWIS } \\
\text { Parameter } \\
\text { code }\end{array}$ & $\begin{array}{l}\text { Laboratory } \\
\text { method code }\end{array}$ & $\begin{array}{c}\text { Reporting } \\
\text { limit' }^{1} \\
(2016)\end{array}$ & $\begin{array}{c}\text { Reporting } \\
\text { limit }^{1} \\
(2017)\end{array}$ & Units & $\begin{array}{c}\text { Method of } \\
\text { quantitation }\end{array}$ & Reference cited \\
\hline 51310 & GC/MS & 0.020 & NA & $\mathrm{ng} / \mathrm{L}$ & MDL & Hladik and others, 2014 \\
\hline 51317 & GC/MS & 0.020 & NA & $\mathrm{ng} / \mathrm{L}$ & MDL & Hladik and others, 2014 \\
\hline 51311 & GC/MS & 0.040 & NA & $\mathrm{ng} / \mathrm{L}$ & MDL & Hladik and others, 2014 \\
\hline 51318 & GC/MS & 0.100 & NA & $\mathrm{ng} / \mathrm{L}$ & MDL & Hladik and others, 2014 \\
\hline 68572 & GC/MS & NA & 5.1 & $\mathrm{ng} / \mathrm{L}$ & MDL & Hladik and others, 2008 \\
\hline 68373 & GC/MS & 6.00 & 6.00 & $\mathrm{ng} / \mathrm{L}$ & MDL & Hladik and others, 2008 \\
\hline 68379 & GC/MS & 5.50 & 5.50 & $\mathrm{ng} / \mathrm{L}$ & MDL & Hladik and others, 2008 \\
\hline 51837 & GC/MS & 1.6 & 1.6 & $\mathrm{ng} / \mathrm{L}$ & MDL & $\begin{array}{l}\text { Hladik and others, } 2008 \\
\quad \text { (additional compound) }\end{array}$ \\
\hline 65080 & GC/MS & 1.50 & 1.50 & $\mathrm{ng} / \mathrm{L}$ & MDL & Hladik and others, 2008 \\
\hline 65081 & GC/MS & 3.90 & 3.90 & $\mathrm{ng} / \mathrm{L}$ & MDL & Hladik and others, 2008 \\
\hline 51848 & GC/MS & 5.10 & 5.10 & $\mathrm{ng} / \mathrm{L}$ & MDL & $\begin{array}{l}\text { Hladik and others, } 2008 \\
\quad \text { (additional compound) }\end{array}$ \\
\hline 67613 & $\mathrm{GC} / \mathrm{MS}$ & 6.50 & 6.50 & $\mathrm{ng} / \mathrm{L}$ & MDL & Hladik and others, 2008 \\
\hline 67618 & GC/MS & 5.20 & 5.20 & $\mathrm{ng} / \mathrm{L}$ & MDL & Hladik and others, 2008 \\
\hline 67622 & GC/MS & 7.60 & 7.60 & $\mathrm{ng} / \mathrm{L}$ & MDL & Hladik and others, 2008 \\
\hline
\end{tabular}


Table 2. Chemical compound information for analyses performed by various laboratories for the U.S. Geological Survey, Environmental Health Mission Area, Infrastructure Project, Tapwater Exposure Pilot Study, 2016-17.-Continued

[NWIS, National Water Information System; CAS, Chemical Abstract Services; y, year; NA, not available; EPA, U.S. Environmental Protection Agency; RED01, enzyme reduction-diazotization; GC, gas chromatograph; LC, liquid chromatography; ICP-MS, inductively coupled plasma-mass spectrometry; cICP-MS, cell inductively coupled plasma-mass spectrometry; HPLC/MS-MS, high performance liquid chromatography/tandem mass spectrometry; HCO3, bicarbonate; $\mu \mathrm{S} / \mathrm{cm}$, microsiemens per centimeter; $\mu \mathrm{g} / \mathrm{L}$, micrograms per liter; $\mathrm{mg} / \mathrm{L}$, milligrams per liter; ng/L, nanograms per liter; DAI-LC/MS-MS, direct aqueous injection-liquid chromatography/tandem mass spectrometry; ICP-OES, inductively coupled plasma-optical emission spectrometry; IC, ion chromatography; GCM66, ambient purgeable method (GC/MS); GM016, heat purgeable method (GC/MS); GC/MS-MS, gas chromatography/tandem mass spectrometry; LC/MS-MS, liquid chromatography-tandem mass spectrometry; ELISA, enzyme linked immunosorbent assay for algal toxins; MDL, method detection limit; MRL, minimum reporting level; IRL, interim reporting level; LOQ, limit of quantification; RLDQC, reporting limit by (DQCALC)]

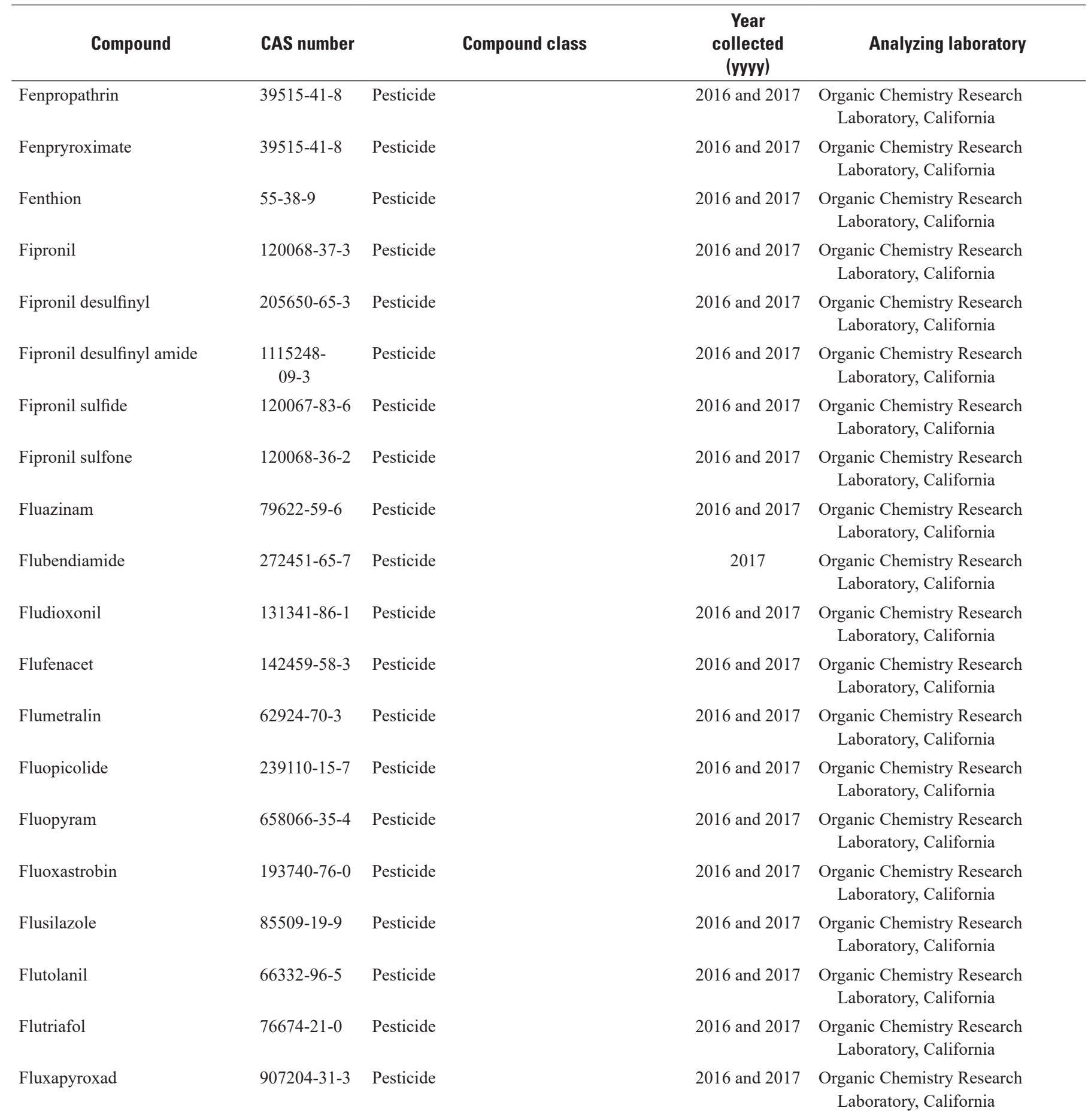


Table 2. Chemical compound information for analyses performed by various laboratories for the U.S. Geological Survey, Environmental Health Mission Area, Infrastructure Project, Tapwater Exposure Pilot Study, 2016-17. —Continued

[NWIS, National Water Information System; CAS, Chemical Abstract Services; y, year; NA, not available; EPA, U.S. Environmental Protection Agency; RED01, enzyme reduction-diazotization; GC, gas chromatograph; LC, liquid chromatography; ICP-MS, inductively coupled plasma- mass spectrometry; cICP-MS, cell inductively coupled plasma-mass spectrometry; HPLC/MS-MS, high performance liquid chromatography-tandem mass spectrometry; HCO3, bicarbonate; $\mu \mathrm{S} / \mathrm{cm}$, microsiemens per centimeter; $\mu \mathrm{g} / \mathrm{L}$, micrograms per liter; $\mathrm{mg} / \mathrm{L}$, milligrams per liter; ng/L, nanograms per liter; DAI-LC/MS-MS, direct aqueous injection-liquid chromatography/tandem mass spectrometry; ICP-OES, inductively coupled plasma-optical emission spectrometry; IC, ion chromatography; GCM66, ambient purgeable method (GC/MS); GM016, heat purgeable method (GC/MS); GC/MS-MS, gas chromatography, tandem mass spectrometry; LC/MS-MS, liquid chromatography-tandem mass spectrometry; ELISA, enzyme linked immunosorbent assay for algal toxins; MDL, method detection limit; MRL, minimum reporting level; IRL, interim reporting level; LOQ, limit of quantification; RLDQC, reporting limit by (DQCALC)]

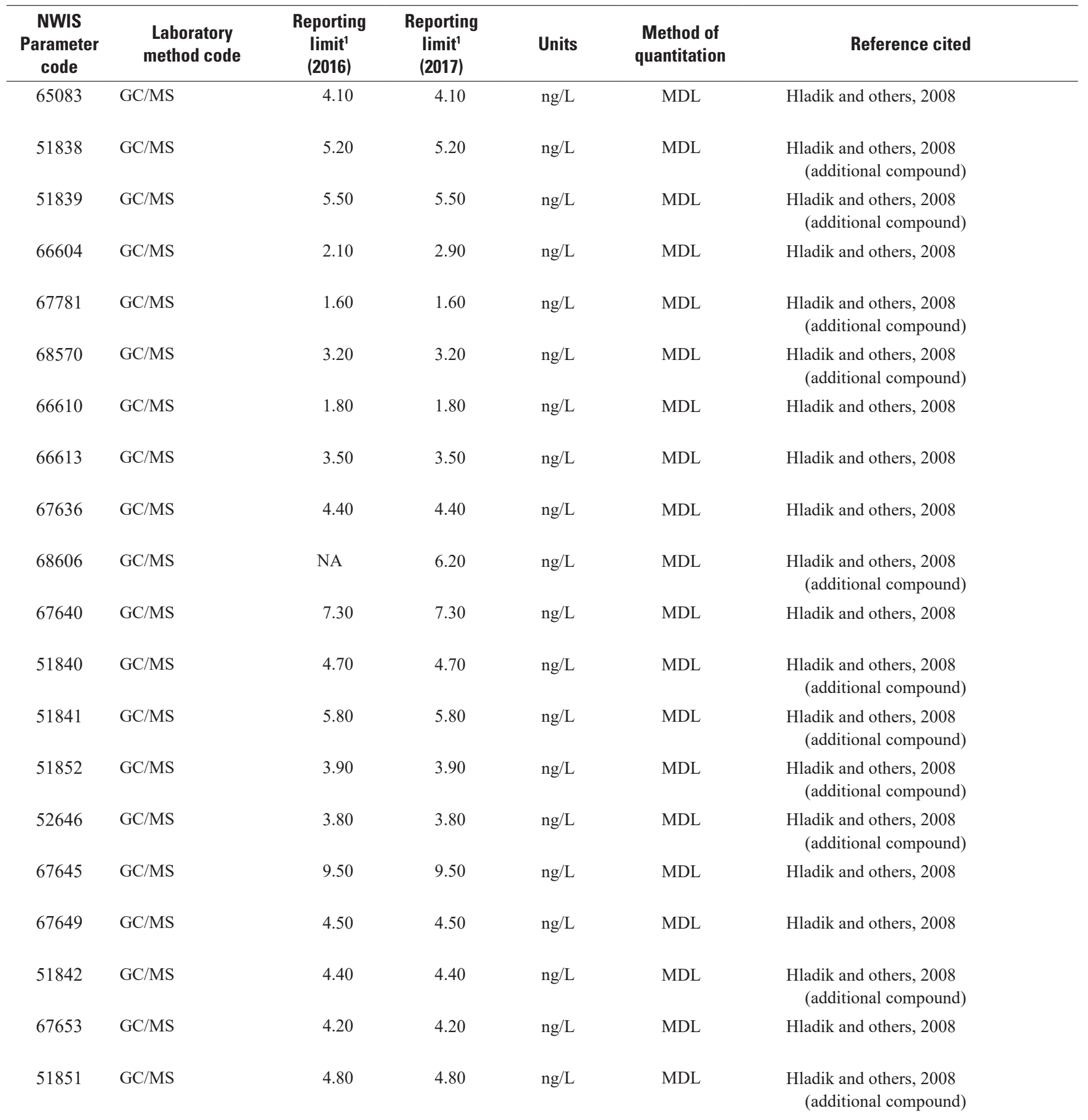


Table 2. Chemical compound information for analyses performed by various laboratories for the U.S. Geological Survey, Environmental Health Mission Area, Infrastructure Project, Tapwater Exposure Pilot Study, 2016-17._Continued

[NWIS, National Water Information System; CAS, Chemical Abstract Services; y, year; NA, not available; EPA, U.S. Environmental Protection Agency; RED01, enzyme reduction-diazotization; GC, gas chromatograph; LC, liquid chromatography; ICP-MS, inductively coupled plasma-mass spectrometry; cICP-MS, cell inductively coupled plasma-mass spectrometry; HPLC/MS-MS, high performance liquid chromatography/tandem mass spectrometry; HCO3, bicarbonate; $\mu \mathrm{S} / \mathrm{cm}$, microsiemens per centimeter; $\mu \mathrm{g} / \mathrm{L}$, micrograms per liter; $\mathrm{mg} / \mathrm{L}$, milligrams per liter; ng/L, nanograms per liter; DAI-LC/MS-MS, direct aqueous injection-liquid chromatography/tandem mass spectrometry; ICP-OES, inductively coupled plasma-optical emission spectrometry; IC, ion chromatography; GCM66, ambient purgeable method (GC/MS); GM016, heat purgeable method (GC/MS); GC/MS-MS, gas chromatography/tandem mass spectrometry; LC/MS-MS, liquid chromatography-tandem mass spectrometry; ELISA, enzyme linked immunosorbent assay for algal toxins; MDL, method detection limit; MRL, minimum reporting level; IRL, interim reporting level; LOQ, limit of quantification; RLDQC, reporting limit by (DQCALC)]

\begin{tabular}{|c|c|c|c|c|}
\hline Compound & CAS number & Compound class & $\begin{array}{c}\text { Year } \\
\text { collected } \\
\text { (yyyy) }\end{array}$ & Analyzing laboratory \\
\hline Hexazinone & $51235-04-2$ & Pesticide & 2016 and 2017 & $\begin{array}{l}\text { Organic Chemistry Research } \\
\text { Laboratory, California }\end{array}$ \\
\hline Imazalil & $35554-44-0$ & Pesticide & 2016 and 2017 & $\begin{array}{l}\text { Organic Chemistry Research } \\
\text { Laboratory, California }\end{array}$ \\
\hline Indoxacarb & $173584-44-6$ & Pesticide & 2017 & $\begin{array}{l}\text { Organic Chemistry Research } \\
\text { Laboratory, California }\end{array}$ \\
\hline Ipconazole & $125225-28-7$ & Pesticide & 2016 and 2017 & $\begin{array}{l}\text { Organic Chemistry Research } \\
\text { Laboratory, California }\end{array}$ \\
\hline Kresoxim-methyl & $143390-89-0$ & Pesticide & 2016 and 2017 & $\begin{array}{l}\text { Organic Chemistry Research } \\
\text { Laboratory, California }\end{array}$ \\
\hline Malathion & $121-75-5$ & Pesticide & 2016 and 2017 & $\begin{array}{l}\text { Organic Chemistry Research } \\
\text { Laboratory, California }\end{array}$ \\
\hline Malathion OA (malaoxon) & $1634-78-2$ & Pesticide & 2016 and 2017 & $\begin{array}{l}\text { Organic Chemistry Research } \\
\text { Laboratory, California }\end{array}$ \\
\hline Metalaxyl & $57837-19-1$ & Pesticide & 2016 and 2017 & $\begin{array}{l}\text { Organic Chemistry Research } \\
\text { Laboratory, California }\end{array}$ \\
\hline Metconazole & $125116-23-6$ & Pesticide & 2016 and 2017 & $\begin{array}{l}\text { Organic Chemistry Research } \\
\text { Laboratory, California }\end{array}$ \\
\hline Metolachlor & $51218-45-2$ & Pesticide & 2016 and 2017 & $\begin{array}{l}\text { Organic Chemistry Research } \\
\text { Laboratory, California }\end{array}$ \\
\hline Molinate & $2212-67-1$ & Pesticide & 2016 and 2017 & $\begin{array}{l}\text { Organic Chemistry Research } \\
\text { Laboratory, California }\end{array}$ \\
\hline Myclobutanil & $88671-89-0$ & Pesticide & 2016 and 2017 & $\begin{array}{l}\text { Organic Chemistry Research } \\
\text { Laboratory, California }\end{array}$ \\
\hline Napropamide & $15299-99-7$ & Pesticide & 2016 and 2017 & $\begin{array}{l}\text { Organic Chemistry Research } \\
\text { Laboratory, California }\end{array}$ \\
\hline Novaluron & $116714-46-6$ & Pesticide & 2016 and 2017 & $\begin{array}{l}\text { Organic Chemistry Research } \\
\text { Laboratory, California }\end{array}$ \\
\hline
\end{tabular}


Table 2. Chemical compound information for analyses performed by various laboratories for the U.S. Geological Survey, Environmental Health Mission Area, Infrastructure Project, Tapwater Exposure Pilot Study, 2016-17. —Continued

[NWIS, National Water Information System; CAS, Chemical Abstract Services; y, year; NA, not available; EPA, U.S. Environmental Protection Agency; RED01, enzyme reduction-diazotization; GC, gas chromatograph; LC, liquid chromatography; ICP-MS, inductively coupled plasma- mass spectrometry; cICP-MS, cell inductively coupled plasma-mass spectrometry; HPLC/MS-MS, high performance liquid chromatography-tandem mass spectrometry; HCO3, bicarbonate; $\mu \mathrm{S} / \mathrm{cm}$, microsiemens per centimeter; $\mu \mathrm{g} / \mathrm{L}$, micrograms per liter; $\mathrm{mg} / \mathrm{L}$, milligrams per liter; ng/L, nanograms per liter; DAI-LC/MS-MS, direct aqueous injection-liquid chromatography/tandem mass spectrometry; ICP-OES, inductively coupled plasma-optical emission spectrometry; IC, ion chromatography; GCM66, ambient purgeable method (GC/MS); GM016, heat purgeable method (GC/MS); GC/MS-MS, gas chromatography, tandem mass spectrometry; LC/MS-MS, liquid chromatography-tandem mass spectrometry; ELISA, enzyme linked immunosorbent assay for algal toxins; MDL, method detection limit; MRL, minimum reporting level; IRL, interim reporting level; LOQ, limit of quantification; RLDQC, reporting limit by (DQCALC)]

\begin{tabular}{|c|c|c|c|c|c|c|}
\hline $\begin{array}{c}\text { NWIS } \\
\text { Parameter } \\
\text { code }\end{array}$ & $\begin{array}{l}\text { Laboratory } \\
\text { method code }\end{array}$ & $\begin{array}{c}\text { Reporting } \\
\text { limit }^{1} \\
(2016)\end{array}$ & $\begin{array}{c}\text { Reporting } \\
\text { limit }^{1} \\
(2017)\end{array}$ & Units & $\begin{array}{c}\text { Method of } \\
\text { quantitation }\end{array}$ & Reference cited \\
\hline 65085 & $\mathrm{GC} / \mathrm{MS}$ & 8.40 & 8.40 & $\mathrm{ng} / \mathrm{L}$ & MDL & Hladik and others, 2008 \\
\hline 67662 & GC/MS & 10.5 & 10.5 & $\mathrm{ng} / \mathrm{L}$ & MDL & Hladik and others, 2008 \\
\hline 68627 & GC/MS & NA & 4.90 & $\mathrm{ng} / \mathrm{L}$ & MDL & $\begin{array}{l}\text { Hladik and others, } 2008 \\
\quad \text { (additional compound) }\end{array}$ \\
\hline 52762 & GC/MS & 7.80 & 7.80 & $\mathrm{ng} / \mathrm{L}$ & MDL & $\begin{array}{l}\text { Hladik and others, } 2008 \\
\quad \text { (additional compound) }\end{array}$ \\
\hline 66617 & GC/MS & 4.40 & 4.40 & $\mathrm{ng} / \mathrm{L}$ & MDL & Hladik and others, 2008 \\
\hline 67670 & GC/MS & 4.00 & 4.00 & $\mathrm{ng} / \mathrm{L}$ & MDL & Hladik and others, 2008 \\
\hline 65087 & GC/MS & 3.70 & 3.70 & $\mathrm{ng} / \mathrm{L}$ & MDL & Hladik and others, 2008 \\
\hline 68240 & GC/MS & 5.00 & 5.00 & $\mathrm{ng} / \mathrm{L}$ & MDL & $\begin{array}{l}\text { Hladik and others, } 2008 \\
\quad \text { (additional compound) }\end{array}$ \\
\hline 68437 & $\mathrm{GC} / \mathrm{MS}$ & 5.10 & 5.10 & $\mathrm{ng} / \mathrm{L}$ & MDL & Hladik and others, 2008 \\
\hline 66620 & GC/MS & 5.20 & 5.20 & $\mathrm{ng} / \mathrm{L}$ & MDL & Hladik and others, 2008 \\
\hline 65091 & GC/MS & 3.20 & 3.20 & $\mathrm{ng} / \mathrm{L}$ & MDL & Hladik and others, 2008 \\
\hline 66632 & $\mathrm{GC} / \mathrm{MS}$ & 6.00 & 6.00 & $\mathrm{ng} / \mathrm{L}$ & MDL & Hladik and others, 2008 \\
\hline 65092 & $\mathrm{GC} / \mathrm{MS}$ & 8.20 & 8.20 & $\mathrm{ng} / \mathrm{L}$ & MDL & Hladik and others, 2008 \\
\hline 68655 & GC/MS & 2.90 & 2.90 & $\mathrm{ng} / \mathrm{L}$ & MDL & $\begin{array}{l}\text { Hladik and others, } 2008 \\
\quad \text { (additional compound) }\end{array}$ \\
\hline
\end{tabular}


Table 2. Chemical compound information for analyses performed by various laboratories for the U.S. Geological Survey, Environmental Health Mission Area, Infrastructure Project, Tapwater Exposure Pilot Study, 2016-17._Continued

[NWIS, National Water Information System; CAS, Chemical Abstract Services; y, year; NA, not available; EPA, U.S. Environmental Protection Agency; RED01, enzyme reduction-diazotization; GC, gas chromatograph; LC, liquid chromatography; ICP-MS, inductively coupled plasma-mass spectrometry; cICP-MS, cell inductively coupled plasma-mass spectrometry; HPLC/MS-MS, high performance liquid chromatography/tandem mass spectrometry; HCO3, bicarbonate; $\mu \mathrm{S} / \mathrm{cm}$, microsiemens per centimeter; $\mu \mathrm{g} / \mathrm{L}$, micrograms per liter; $\mathrm{mg} / \mathrm{L}$, milligrams per liter; ng/L, nanograms per liter; DAI-LC/MS-MS, direct aqueous injection-liquid chromatography/tandem mass spectrometry; ICP-OES, inductively coupled plasma-optical emission spectrometry; IC, ion chromatography; GCM66, ambient purgeable method (GC/MS); GM016, heat purgeable method (GC/MS); GC/MS-MS, gas chromatography/tandem mass spectrometry; LC/MS-MS, liquid chromatography-tandem mass spectrometry; ELISA, enzyme linked immunosorbent assay for algal toxins; MDL, method detection limit; MRL, minimum reporting level; IRL, interim reporting level; LOQ, limit of quantification; RLDQC, reporting limit by (DQCALC)]

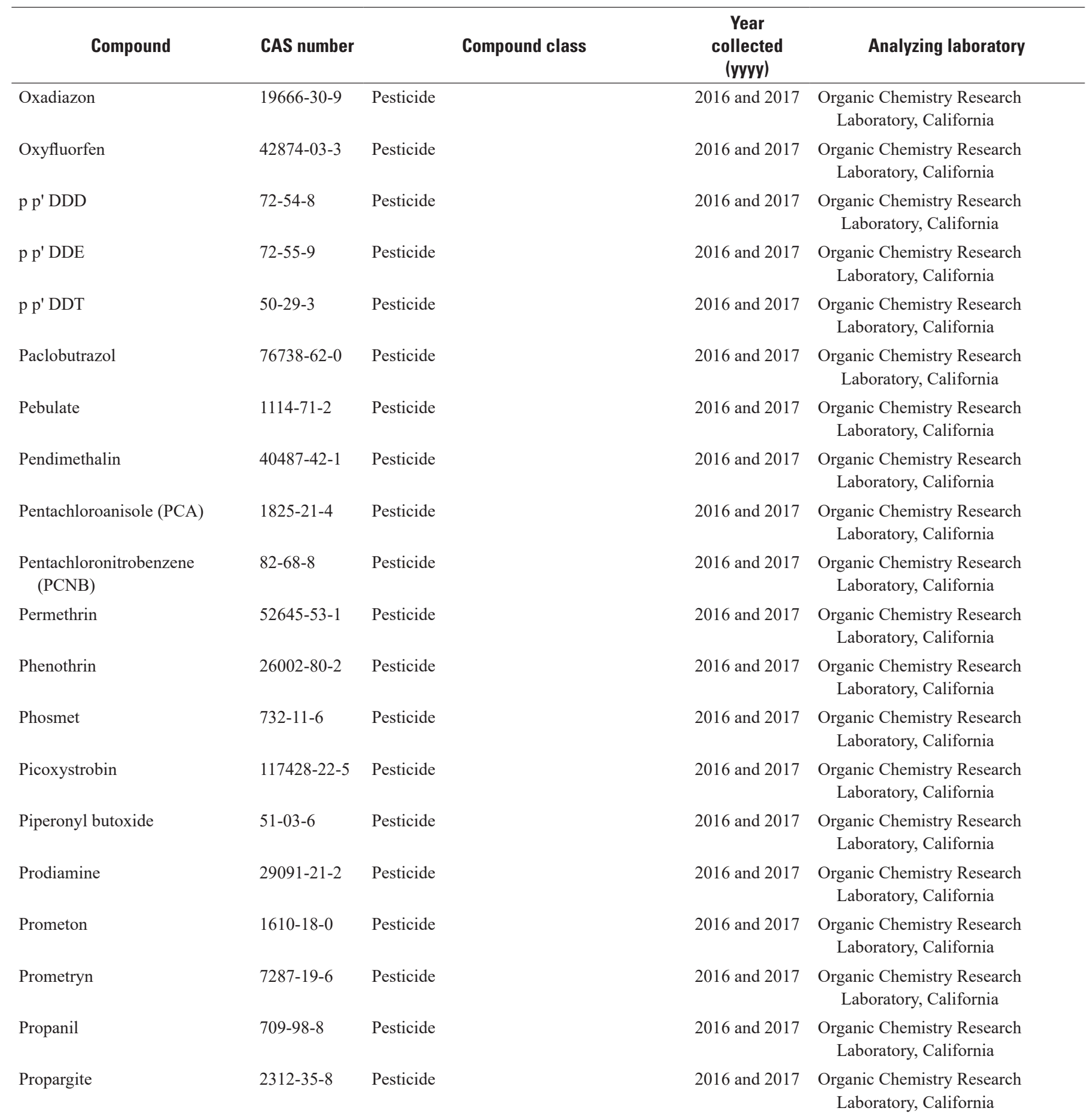


Table 2. Chemical compound information for analyses performed by various laboratories for the U.S. Geological Survey, Environmental Health Mission Area, Infrastructure Project, Tapwater Exposure Pilot Study, 2016-17. —Continued

[NWIS, National Water Information System; CAS, Chemical Abstract Services; y, year; NA, not available; EPA, U.S. Environmental Protection Agency; RED01, enzyme reduction-diazotization; GC, gas chromatograph; LC, liquid chromatography; ICP-MS, inductively coupled plasma- mass spectrometry; cICP-MS, cell inductively coupled plasma-mass spectrometry; HPLC/MS-MS, high performance liquid chromatography-tandem mass spectrometry; HCO3, bicarbonate; $\mu \mathrm{S} / \mathrm{cm}$, microsiemens per centimeter; $\mu \mathrm{g} / \mathrm{L}$, micrograms per liter; $\mathrm{mg} / \mathrm{L}$, milligrams per liter; ng/L, nanograms per liter; DAI-LC/MS-MS, direct aqueous injection-liquid chromatography/tandem mass spectrometry; ICP-OES, inductively coupled plasma-optical emission spectrometry; IC, ion chromatography; GCM66, ambient purgeable method (GC/MS); GM016, heat purgeable method (GC/MS); GC/MS-MS, gas chromatography, tandem mass spectrometry; LC/MS-MS, liquid chromatography-tandem mass spectrometry; ELISA, enzyme linked immunosorbent assay for algal toxins; MDL, method detection limit; MRL, minimum reporting level; IRL, interim reporting level; LOQ, limit of quantification; RLDQC, reporting limit by (DQCALC)]

\begin{tabular}{|c|c|c|c|c|c|c|}
\hline $\begin{array}{c}\text { NWIS } \\
\text { Parameter } \\
\text { code }\end{array}$ & $\begin{array}{l}\text { Laboratory } \\
\text { method code }\end{array}$ & $\begin{array}{c}\text { Reporting } \\
\text { limit }^{1} \\
(2016)\end{array}$ & $\begin{array}{c}\text { Reporting } \\
\text { limit }^{1} \\
(2017)\end{array}$ & Units & $\begin{array}{c}\text { Method of } \\
\text { quantitation }\end{array}$ & Reference cited \\
\hline 51843 & $\mathrm{GC} / \mathrm{MS}$ & 2.10 & 2.10 & $\mathrm{ng} / \mathrm{L}$ & MDL & $\begin{array}{l}\text { Hladik and others, } 2008 \\
\quad \text { (additional compound) }\end{array}$ \\
\hline 65093 & GC/MS & 3.10 & 3.10 & $\mathrm{ng} / \mathrm{L}$ & MDL & Hladik and others, 2008 \\
\hline 65095 & GC/MS & 3.60 & 3.60 & $\mathrm{ng} / \mathrm{L}$ & MDL & Hladik and others, 2008 \\
\hline 65096 & GC/MS & 4.00 & 4.00 & $\mathrm{ng} / \mathrm{L}$ & MDL & Hladik and others, 2008 \\
\hline 51846 & GC/MS & 6.20 & 6.20 & $\mathrm{ng} / \mathrm{L}$ & MDL & $\begin{array}{l}\text { Hladik and others, } 2008 \\
\quad \text { (additional compound) }\end{array}$ \\
\hline 65098 & GC/MS & 2.30 & 2.30 & $\mathrm{ng} / \mathrm{L}$ & MDL & Hladik and others, 2008 \\
\hline 66637 & GC/MS & 4.70 & 4.70 & $\mathrm{ng} / \mathrm{L}$ & MDL & Hladik and others, 2008 \\
\hline 66639 & GC/MS & 3.10 & 3.10 & $\mathrm{ng} / \mathrm{L}$ & MDL & Hladik and others, 2008 \\
\hline 65099 & GC/MS & 3.40 & 3.40 & $\mathrm{ng} / \mathrm{L}$ & MDL & Hladik and others, 2008 \\
\hline 65100 & GC/MS & 5.10 & 5.10 & $\mathrm{ng} / \mathrm{L}$ & MDL & Hladik and others, 2008 \\
\hline 67702 & GC/MS & 2.50 & 2.50 & $\mathrm{ng} / \mathrm{L}$ & MDL & Hladik and others, 2008 \\
\hline 65103 & $\mathrm{GC} / \mathrm{MS}$ & 1.80 & 1.80 & $\mathrm{ng} / \mathrm{L}$ & MDL & Hladik and others, 2008 \\
\hline 66641 & $\mathrm{GC} / \mathrm{MS}$ & 10.1 & 10.1 & $\mathrm{ng} / \mathrm{L}$ & MDL & Hladik and others, 2008 \\
\hline 68677 & GC/MS & 6.10 & 6.10 & $\mathrm{ng} / \mathrm{L}$ & MDL & $\begin{array}{l}\text { Hladik and others, } 2008 \\
\quad \text { (additional compound) }\end{array}$ \\
\hline
\end{tabular}


Table 2. Chemical compound information for analyses performed by various laboratories for the U.S. Geological Survey, Environmental Health Mission Area, Infrastructure Project, Tapwater Exposure Pilot Study, 2016-17._Continued

[NWIS, National Water Information System; CAS, Chemical Abstract Services; y, year; NA, not available; EPA, U.S. Environmental Protection Agency; RED01, enzyme reduction-diazotization; GC, gas chromatograph; LC, liquid chromatography; ICP-MS, inductively coupled plasma-mass spectrometry; cICP-MS, cell inductively coupled plasma-mass spectrometry; HPLC/MS-MS, high performance liquid chromatography/tandem mass spectrometry; HCO3, bicarbonate; $\mu \mathrm{S} / \mathrm{cm}$, microsiemens per centimeter; $\mu \mathrm{g} / \mathrm{L}$, micrograms per liter; $\mathrm{mg} / \mathrm{L}$, milligrams per liter; ng/L, nanograms per liter; DAI-LC/MS-MS, direct aqueous injection-liquid chromatography/tandem mass spectrometry; ICP-OES, inductively coupled plasma-optical emission spectrometry; IC, ion chromatography; GCM66, ambient purgeable method (GC/MS); GM016, heat purgeable method (GC/MS); GC/MS-MS, gas chromatography/tandem mass spectrometry; LC/MS-MS, liquid chromatography-tandem mass spectrometry; ELISA, enzyme linked immunosorbent assay for algal toxins; MDL, method detection limit; MRL, minimum reporting level; IRL, interim reporting level; LOQ, limit of quantification; RLDQC, reporting limit by (DQCALC)]

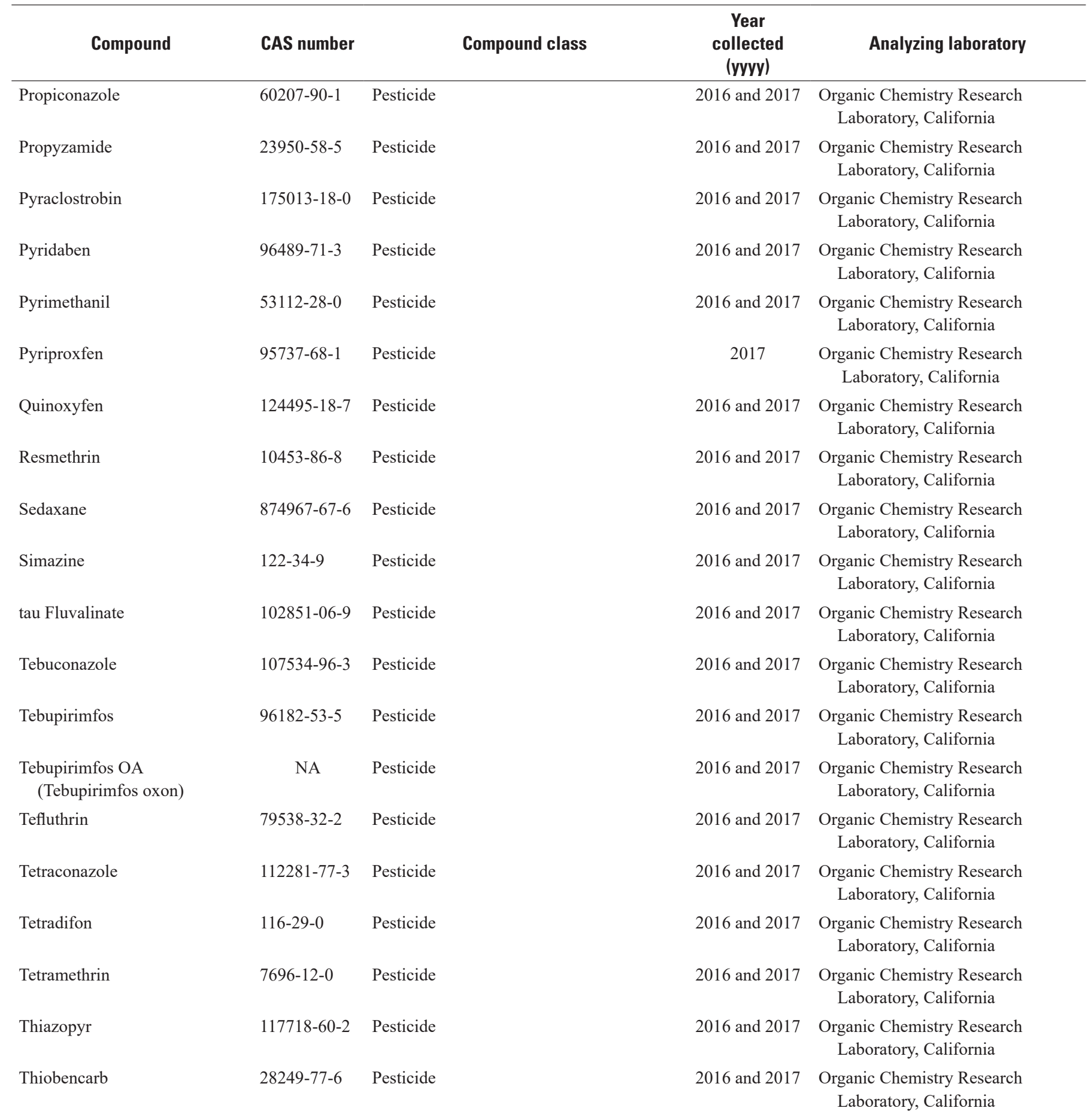


Table 2. $\quad 41$

Table 2. Chemical compound information for analyses performed by various laboratories for the U.S. Geological Survey, Environmental Health Mission Area, Infrastructure Project, Tapwater Exposure Pilot Study, 2016-17. —Continued

[NWIS, National Water Information System; CAS, Chemical Abstract Services; y, year; NA, not available; EPA, U.S. Environmental Protection Agency; RED01, enzyme reduction-diazotization; GC, gas chromatograph; LC, liquid chromatography; ICP-MS, inductively coupled plasma- mass spectrometry; cICP-MS, cell inductively coupled plasma-mass spectrometry; HPLC/MS-MS, high performance liquid chromatography-tandem mass spectrometry; HCO3, bicarbonate; $\mu \mathrm{S} / \mathrm{cm}$, microsiemens per centimeter; $\mu \mathrm{g} / \mathrm{L}$, micrograms per liter; $\mathrm{mg} / \mathrm{L}$, milligrams per liter; ng/L, nanograms per liter; DAI-LC/MS-MS, direct aqueous injection-liquid chromatography/tandem mass spectrometry; ICP-OES, inductively coupled plasma-optical emission spectrometry; IC, ion chromatography; GCM66, ambient purgeable method (GC/MS); GM016, heat purgeable method (GC/MS); GC/MS-MS, gas chromatography, tandem mass spectrometry; LC/MS-MS, liquid chromatography-tandem mass spectrometry; ELISA, enzyme linked immunosorbent assay for algal toxins; MDL, method detection limit; MRL, minimum reporting level; IRL, interim reporting level; LOQ, limit of quantification; RLDQC, reporting limit by (DQCALC)]

\begin{tabular}{|c|c|c|c|c|c|c|}
\hline $\begin{array}{c}\text { NWIS } \\
\text { Parameter } \\
\text { code }\end{array}$ & $\begin{array}{l}\text { Laboratory } \\
\text { method code }\end{array}$ & $\begin{array}{c}\text { Reporting } \\
\text { limit }^{1} \\
(2016)\end{array}$ & $\begin{array}{c}\text { Reporting } \\
\text { limit }^{1} \\
(2017)\end{array}$ & Units & $\begin{array}{c}\text { Method of } \\
\text { quantitation }\end{array}$ & Reference cited \\
\hline 66643 & GC/MS & 5.00 & 8.80 & $\mathrm{ng} / \mathrm{L}$ & MDL & Hladik and others, 2008 \\
\hline 67706 & GC/MS & 5.00 & 5.00 & $\mathrm{ng} / \mathrm{L}$ & MDL & Hladik and others, 2008 \\
\hline 68682 & $\mathrm{GC} / \mathrm{MS}$ & 5.40 & 5.40 & $\mathrm{ng} / \mathrm{L}$ & MDL & $\begin{array}{l}\text { Hladik and others, } 2008 \\
\quad \text { (additional compound) }\end{array}$ \\
\hline 67717 & GC/MS & 4.10 & 4.10 & $\mathrm{ng} / \mathrm{L}$ & MDL & Hladik and others, 2008 \\
\hline 68683 & $\mathrm{GC} / \mathrm{MS}$ & NA & 5.20 & $\mathrm{ng} / \mathrm{L}$ & MDL & $\begin{array}{l}\text { Hladik and others, } 2008 \\
\text { (additional compound) }\end{array}$ \\
\hline 65104 & $\mathrm{GC} / \mathrm{MS}$ & 5.70 & 5.70 & $\mathrm{ng} / \mathrm{L}$ & MDL & Hladik and others, 2008 \\
\hline 52648 & GC/MS & 5.20 & 5.20 & $\mathrm{ng} / \mathrm{L}$ & MDL & $\begin{array}{l}\text { Hladik and others, } 2008 \\
\quad \text { (additional compound) }\end{array}$ \\
\hline 65105 & GC/MS & 5.00 & 5.00 & $\mathrm{ng} / \mathrm{L}$ & MDL & Hladik and others, 2008 \\
\hline 65106 & GC/MS & 5.30 & 5.30 & $\mathrm{ng} / \mathrm{L}$ & MDL & Hladik and others, 2008 \\
\hline 66649 & GC/MS & 3.70 & 3.70 & $\mathrm{ng} / \mathrm{L}$ & MDL & Hladik and others, 2008 \\
\hline 51651 & GC/MS & 3.80 & 3.80 & $\mathrm{ng} / \mathrm{L}$ & MDL & $\begin{array}{l}\text { Hladik and others, } 2008 \\
\quad \text { (additional compound) }\end{array}$ \\
\hline 66657 & $\mathrm{GC} / \mathrm{MS}$ & 2.90 & 2.90 & $\mathrm{ng} / \mathrm{L}$ & MDL & Hladik and others, 2008 \\
\hline 51845 & GC/MS & 4.10 & 4.10 & $\mathrm{ng} / \mathrm{L}$ & MDL & $\begin{array}{l}\text { Hladik and others, } 2008 \\
\quad \text { (additional compound) }\end{array}$ \\
\hline 65107 & GC/MS & 1.90 & 1.90 & $\mathrm{ng} / \mathrm{L}$ & MDL & Hladik and others, 2008 \\
\hline
\end{tabular}


Table 2. Chemical compound information for analyses performed by various laboratories for the U.S. Geological Survey, Environmental Health Mission Area, Infrastructure Project, Tapwater Exposure Pilot Study, 2016-17.-Continued

[NWIS, National Water Information System; CAS, Chemical Abstract Services; y, year; NA, not available; EPA, U.S. Environmental Protection Agency; RED01, enzyme reduction-diazotization; GC, gas chromatograph; LC, liquid chromatography; ICP-MS, inductively coupled plasma-mass spectrometry; cICP-MS, cell inductively coupled plasma-mass spectrometry; HPLC/MS-MS, high performance liquid chromatography/tandem mass spectrometry; HCO3, bicarbonate; $\mu \mathrm{S} / \mathrm{cm}$, microsiemens per centimeter; $\mu \mathrm{g} / \mathrm{L}$, micrograms per liter; $\mathrm{mg} / \mathrm{L}$, milligrams per liter; ng/L, nanograms per liter; DAI-LC/MS-MS, direct aqueous injection-liquid chromatography/tandem mass spectrometry; ICP-OES, inductively coupled plasma-optical emission spectrometry; IC, ion chromatography; GCM66, ambient purgeable method (GC/MS); GM016, heat purgeable method (GC/MS); GC/MS-MS, gas chromatography/tandem mass spectrometry; LC/MS-MS, liquid chromatography-tandem mass spectrometry; ELISA, enzyme linked immunosorbent assay for algal toxins; MDL, method detection limit; MRL, minimum reporting level; IRL, interim reporting level; LOQ, limit of quantification; RLDQC, reporting limit by (DQCALC)]

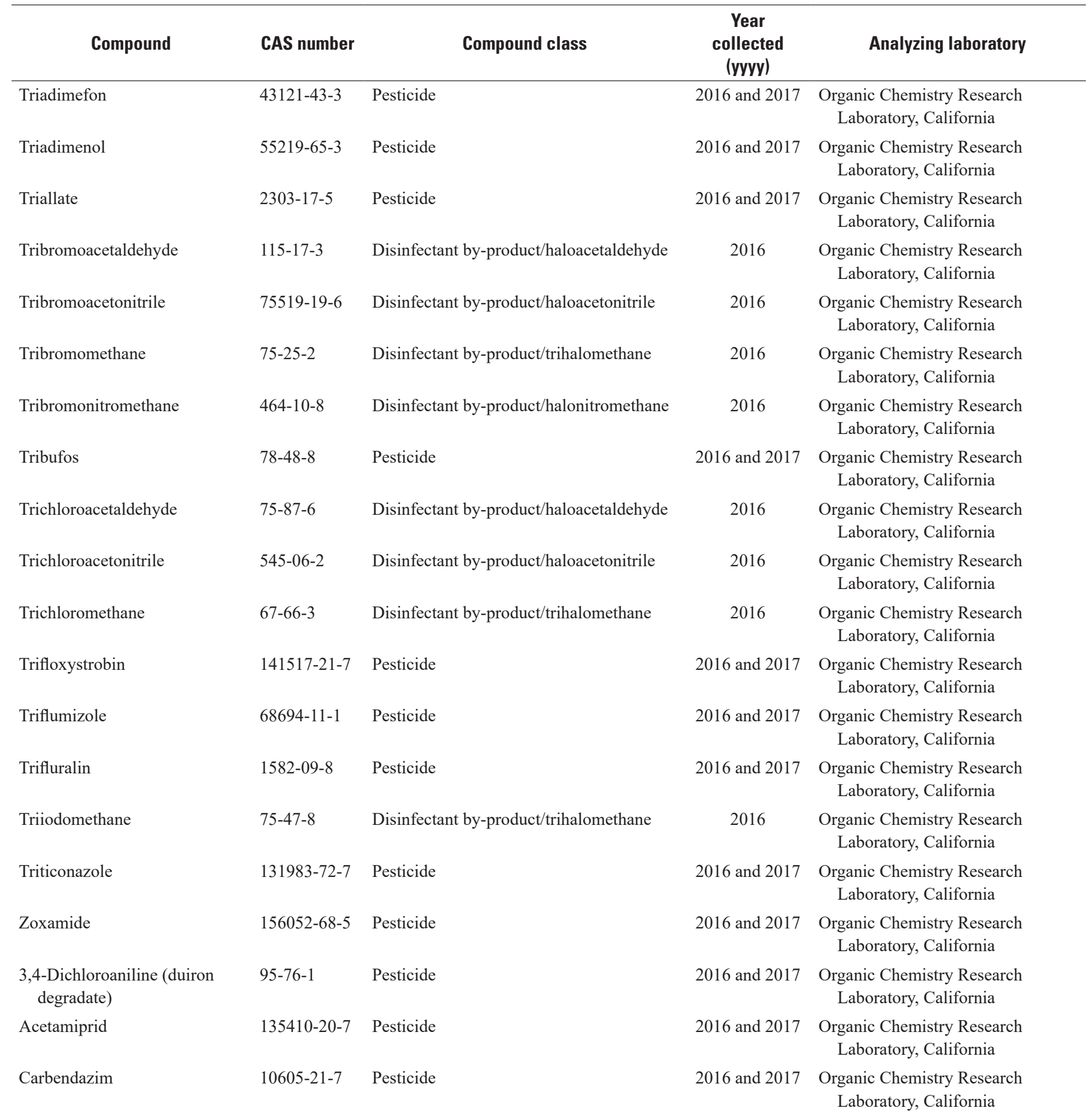


Table 2. $\quad 43$

Table 2. Chemical compound information for analyses performed by various laboratories for the U.S. Geological Survey, Environmental Health Mission Area, Infrastructure Project, Tapwater Exposure Pilot Study, 2016-17. —Continued

[NWIS, National Water Information System; CAS, Chemical Abstract Services; y, year; NA, not available; EPA, U.S. Environmental Protection Agency; RED01, enzyme reduction-diazotization; GC, gas chromatograph; LC, liquid chromatography; ICP-MS, inductively coupled plasma- mass spectrometry; cICP-MS, cell inductively coupled plasma-mass spectrometry; HPLC/MS-MS, high performance liquid chromatography-tandem mass spectrometry; HCO3, bicarbonate; $\mu \mathrm{S} / \mathrm{cm}$, microsiemens per centimeter; $\mu \mathrm{g} / \mathrm{L}$, micrograms per liter; mg/L, milligrams per liter; ng/L, nanograms per liter; DAI-LC/MS-MS, direct aqueous injection-liquid chromatography/tandem mass spectrometry; ICP-OES, inductively coupled plasma-optical emission spectrometry; IC, ion chromatography; GCM66, ambient purgeable method (GC/MS); GM016, heat purgeable method (GC/MS); GC/MS-MS, gas chromatography, tandem mass spectrometry; LC/MS-MS, liquid chromatography-tandem mass spectrometry; ELISA, enzyme linked immunosorbent assay for algal toxins; MDL, method detection limit; MRL, minimum reporting level; IRL, interim reporting level; LOQ, limit of quantification; RLDQC, reporting limit by (DQCALC)]

\begin{tabular}{|c|c|c|c|c|c|c|}
\hline $\begin{array}{c}\text { NWIS } \\
\text { Parameter } \\
\text { code }\end{array}$ & $\begin{array}{l}\text { Laboratory } \\
\text { method code }\end{array}$ & $\begin{array}{c}\text { Reporting } \\
\text { limit }^{1} \\
(2016)\end{array}$ & $\begin{array}{c}\text { Reporting } \\
\text { limit }^{1} \\
(2017)\end{array}$ & Units & $\begin{array}{c}\text { Method of } \\
\text { quantitation }\end{array}$ & Reference cited \\
\hline 67741 & GC/MS & 8.90 & 8.90 & $\mathrm{ng} / \mathrm{L}$ & MDL & Hladik and others, 2008 \\
\hline 67746 & $\mathrm{GC} / \mathrm{MS}$ & 8.00 & 8.00 & $\mathrm{ng} / \mathrm{L}$ & MDL & Hladik and others, 2008 \\
\hline 51328 & $\mathrm{GC} / \mathrm{MS}$ & 0.020 & NA & $\mathrm{ng} / \mathrm{L}$ & MDL & Hladik and others, 2014 \\
\hline 51326 & $\mathrm{GC} / \mathrm{MS}$ & 0.020 & NA & $\mathrm{ng} / \mathrm{L}$ & MDL & Hladik and others, 2014 \\
\hline 34288 & GC/MS & 0.020 & NA & $\mathrm{ng} / \mathrm{L}$ & MDL & Hladik and others, 2014 \\
\hline 68711 & GC/MS & 3.10 & 3.10 & $\mathrm{ng} / \mathrm{L}$ & MDL & $\begin{array}{l}\text { Hladik and others, } 2008 \\
\quad \text { (additional compound) }\end{array}$ \\
\hline 51329 & GC/MS & 0.200 & NA & $\mathrm{ng} / \mathrm{L}$ & MDL & Hladik and others, 2014 \\
\hline 51327 & GC/MS & 0.020 & NA & $\mathrm{ng} / \mathrm{L}$ & MDL & Hladik and others, 2014 \\
\hline 34316 & $\mathrm{GC} / \mathrm{MS}$ & 0.020 & NA & $\mathrm{ng} / \mathrm{L}$ & MDL & Hladik and others, 2014 \\
\hline 66660 & $\mathrm{GC} / \mathrm{MS}$ & 4.70 & 4.70 & $\mathrm{ng} / \mathrm{L}$ & MDL & Hladik and others, 2008 \\
\hline 67768 & GC/MS & 3.50 & 3.50 & $\mathrm{ng} / \mathrm{L}$ & MDL & Hladik and others, 2008 \\
\hline 66584 & LC/MS-MS & 3.20 & 3.20 & $\mathrm{ng} / \mathrm{L}$ & MDL & Hladik and Calhoun, 2012 \\
\hline 68302 & LC/MS-MS & 3.30 & 3.30 & $\mathrm{ng} / \mathrm{L}$ & MDL & Hladik and Calhoun, 2012 \\
\hline 68548 & LC/MS-MS & 4.20 & 4.20 & $\mathrm{ng} / \mathrm{L}$ & MDL & $\begin{array}{l}\text { Hladik and Calhoun, } 2012 \\
\quad \text { (additional compound) }\end{array}$ \\
\hline
\end{tabular}


Table 2. Chemical compound information for analyses performed by various laboratories for the U.S. Geological Survey, Environmental Health Mission Area, Infrastructure Project, Tapwater Exposure Pilot Study, 2016-17.-Continued

[NWIS, National Water Information System; CAS, Chemical Abstract Services; y, year; NA, not available; EPA, U.S. Environmental Protection Agency; RED01, enzyme reduction-diazotization; GC, gas chromatograph; LC, liquid chromatography; ICP-MS, inductively coupled plasma-mass spectrometry; cICP-MS, cell inductively coupled plasma-mass spectrometry; HPLC/MS-MS, high performance liquid chromatography/tandem mass spectrometry; HCO3, bicarbonate; $\mu \mathrm{S} / \mathrm{cm}$, microsiemens per centimeter; $\mu \mathrm{g} / \mathrm{L}$, micrograms per liter; $\mathrm{mg} / \mathrm{L}$, milligrams per liter; ng/L, nanograms per liter; DAI-LC/MS-MS, direct aqueous injection-liquid chromatography/tandem mass spectrometry; ICP-OES, inductively coupled plasma-optical emission spectrometry; IC, ion chromatography; GCM66, ambient purgeable method (GC/MS); GM016, heat purgeable method (GC/MS); GC/MS-MS, gas chromatography/tandem mass spectrometry; LC/MS-MS, liquid chromatography-tandem mass spectrometry; ELISA, enzyme linked immunosorbent assay for algal toxins; MDL, method detection limit; MRL, minimum reporting level; IRL, interim reporting level; LOQ, limit of quantification; RLDQC, reporting limit by (DQCALC)]

\begin{tabular}{|c|c|c|c|c|}
\hline Compound & CAS number & Compound class & $\begin{array}{c}\text { Year } \\
\text { collected } \\
\text { (yyyy) }\end{array}$ & Analyzing laboratory \\
\hline Chlorantraniliprole & $500008-45-7$ & Pesticide & 2016 and 2017 & $\begin{array}{l}\text { Organic Chemistry Research } \\
\text { Laboratory, California }\end{array}$ \\
\hline Clothianidin & $210880-92-5$ & Pesticide & 2016 and 2017 & $\begin{array}{l}\text { Organic Chemistry Research } \\
\text { Laboratory, California }\end{array}$ \\
\hline Cyazofamid & $120116-88-3$ & Pesticide & 2016 and 2017 & $\begin{array}{l}\text { Organic Chemistry Research } \\
\text { Laboratory, California }\end{array}$ \\
\hline Cymoxanil & $57966-95-7$ & Pesticide & 2016 and 2017 & $\begin{array}{l}\text { Organic Chemistry Research } \\
\text { Laboratory, California }\end{array}$ \\
\hline DCPMU (diuron degradate) & $3567-62-2$ & Pesticide & 2016 and 2017 & $\begin{array}{l}\text { Organic Chemistry Research } \\
\text { Laboratory, California }\end{array}$ \\
\hline Desthio-prothioconazole & $120983-64-4$ & Pesticide & 2016 and 2017 & $\begin{array}{l}\text { Organic Chemistry Research } \\
\text { Laboratory, California }\end{array}$ \\
\hline Dinotefuran & $165252-70-0$ & Pesticide & 2016 and 2017 & $\begin{array}{l}\text { Organic Chemistry Research } \\
\text { Laboratory, California }\end{array}$ \\
\hline Diuron & $330-54-1$ & Pesticide & 2016 and 2017 & $\begin{array}{l}\text { Organic Chemistry Research } \\
\text { Laboratory, California }\end{array}$ \\
\hline Ethaboxam & $162650-77-3$ & Pesticide & 2016 and 2017 & $\begin{array}{l}\text { Organic Chemistry Research } \\
\text { Laboratory, California }\end{array}$ \\
\hline Flonicamid & $158062-67-0$ & Pesticide & 2016 and 2017 & $\begin{array}{l}\text { Organic Chemistry Research } \\
\text { Laboratory, California }\end{array}$ \\
\hline Mandipropamid & $374726-62-2$ & Pesticide & 2016 and 2017 & $\begin{array}{l}\text { Organic Chemistry Research } \\
\text { Laboratory, California }\end{array}$ \\
\hline Methoxyfenozide & $161050-58-4$ & Pesticide & 2016 and 2017 & $\begin{array}{l}\text { Organic Chemistry Research } \\
\text { Laboratory, California }\end{array}$ \\
\hline Oryzalin & $19044-88-3$ & Pesticide & 2016 and 2017 & $\begin{array}{l}\text { Organic Chemistry Research } \\
\text { Laboratory, California }\end{array}$ \\
\hline Oxathiapiprolin & $\begin{array}{c}1003318- \\
67-9\end{array}$ & Pesticide & 2017 & $\begin{array}{l}\text { Organic Chemistry Research } \\
\text { Laboratory, California }\end{array}$ \\
\hline
\end{tabular}


Table 2. Chemical compound information for analyses performed by various laboratories for the U.S. Geological Survey, Environmental Health Mission Area, Infrastructure Project, Tapwater Exposure Pilot Study, 2016-17. —Continued

[NWIS, National Water Information System; CAS, Chemical Abstract Services; y, year; NA, not available; EPA, U.S. Environmental Protection Agency; RED01, enzyme reduction-diazotization; GC, gas chromatograph; LC, liquid chromatography; ICP-MS, inductively coupled plasma- mass spectrometry; cICP-MS, cell inductively coupled plasma-mass spectrometry; HPLC/MS-MS, high performance liquid chromatography-tandem mass spectrometry; HCO3, bicarbonate; $\mu \mathrm{S} / \mathrm{cm}$, microsiemens per centimeter; $\mu \mathrm{g} / \mathrm{L}$, micrograms per liter; $\mathrm{mg} / \mathrm{L}$, milligrams per liter; ng/L, nanograms per liter; DAI-LC/MS-MS, direct aqueous injection-liquid chromatography/tandem mass spectrometry; ICP-OES, inductively coupled plasma-optical emission spectrometry; IC, ion chromatography; GCM66, ambient purgeable method (GC/MS); GM016, heat purgeable method (GC/MS); GC/MS-MS, gas chromatography, tandem mass spectrometry; LC/MS-MS, liquid chromatography-tandem mass spectrometry; ELISA, enzyme linked immunosorbent assay for algal toxins; MDL, method detection limit; MRL, minimum reporting level; IRL, interim reporting level; LOQ, limit of quantification; RLDQC, reporting limit by (DQCALC)]

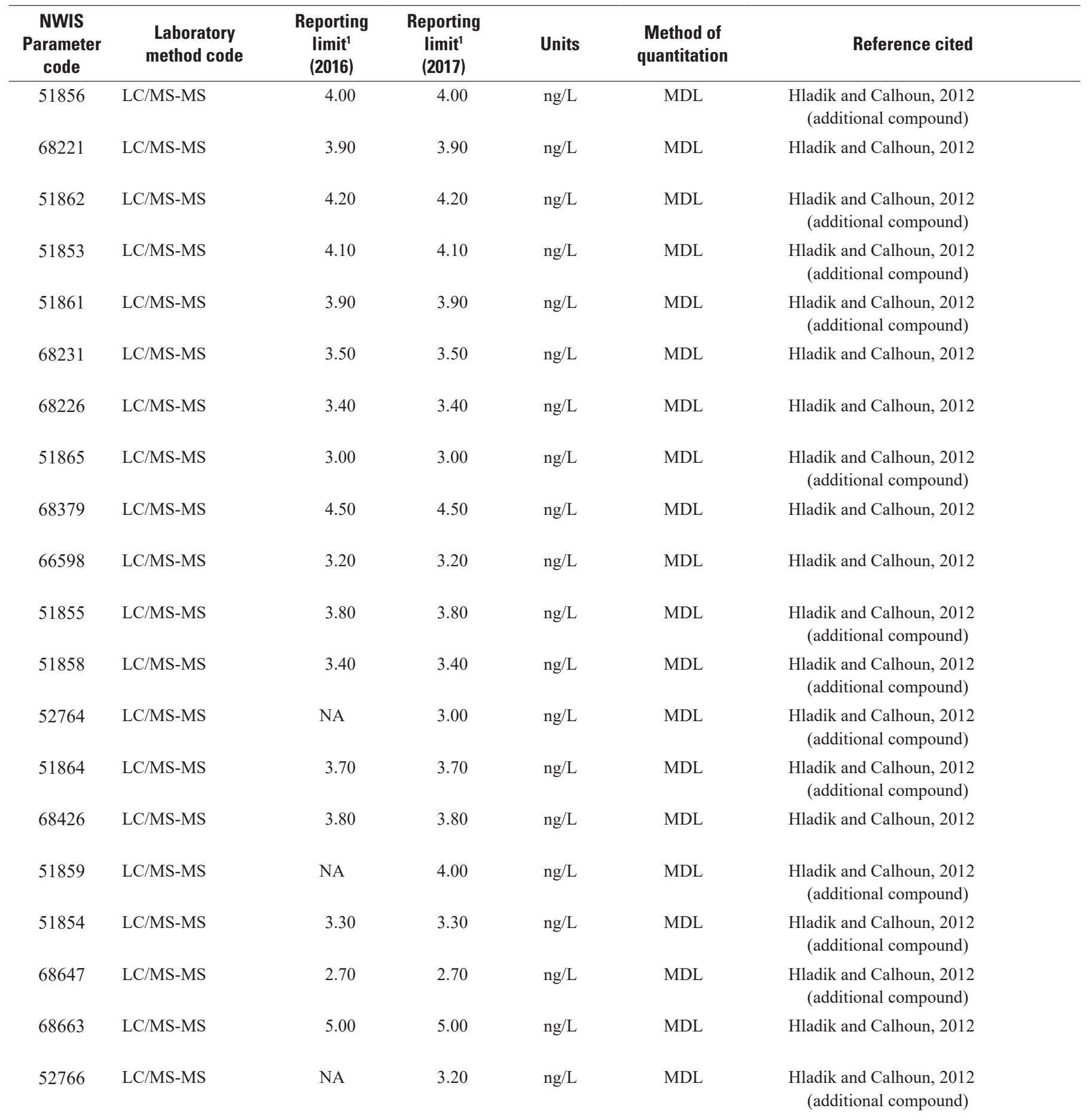


Table 2. Chemical compound information for analyses performed by various laboratories for the U.S. Geological Survey, Environmental Health Mission Area, Infrastructure Project, Tapwater Exposure Pilot Study, 2016-17._Continued

[NWIS, National Water Information System; CAS, Chemical Abstract Services; y, year; NA, not available; EPA, U.S. Environmental Protection Agency; RED01, enzyme reduction-diazotization; GC, gas chromatograph; LC, liquid chromatography; ICP-MS, inductively coupled plasma-mass spectrometry; cICP-MS, cell inductively coupled plasma-mass spectrometry; HPLC/MS-MS, high performance liquid chromatography/tandem mass spectrometry; HCO3, bicarbonate; $\mu \mathrm{S} / \mathrm{cm}$, microsiemens per centimeter; $\mu \mathrm{g} / \mathrm{L}$, micrograms per liter; $\mathrm{mg} / \mathrm{L}$, milligrams per liter; ng/L, nanograms per liter; DAI-LC/MS-MS, direct aqueous injection-liquid chromatography/tandem mass spectrometry; ICP-OES, inductively coupled plasma-optical emission spectrometry; IC, ion chromatography; GCM66, ambient purgeable method (GC/MS); GM016, heat purgeable method (GC/MS); GC/MS-MS, gas chromatography/tandem mass spectrometry; LC/MS-MS, liquid chromatography-tandem mass spectrometry; ELISA, enzyme linked immunosorbent assay for algal toxins; MDL, method detection limit; MRL, minimum reporting level; IRL, interim reporting level; LOQ, limit of quantification; RLDQC, reporting limit by (DQCALC)]

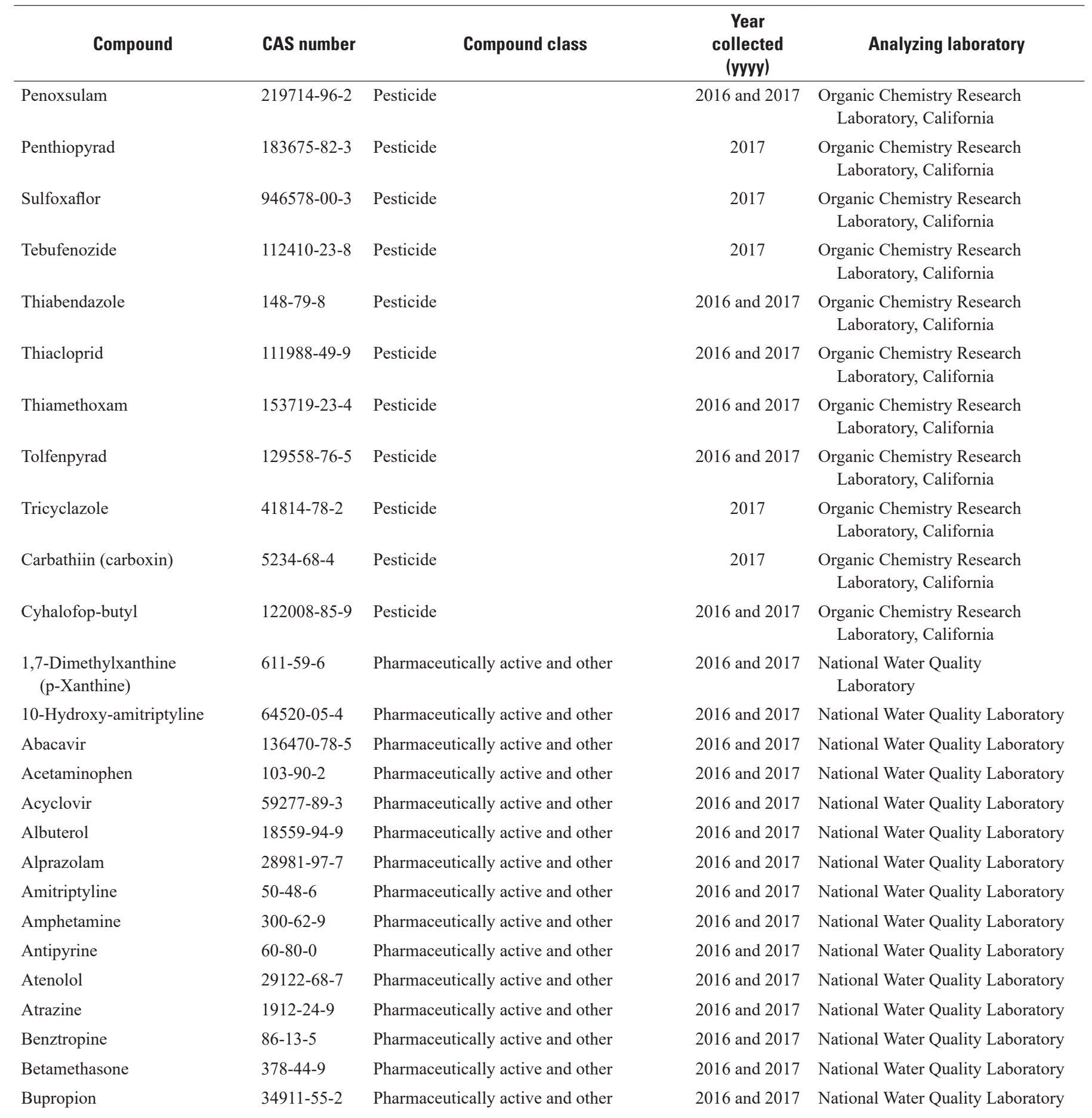


Table 2. Chemical compound information for analyses performed by various laboratories for the U.S. Geological Survey, Environmental Health Mission Area, Infrastructure Project, Tapwater Exposure Pilot Study, 2016-17. —Continued

[NWIS, National Water Information System; CAS, Chemical Abstract Services; y, year; NA, not available; EPA, U.S. Environmental Protection Agency; RED01, enzyme reduction-diazotization; GC, gas chromatograph; LC, liquid chromatography; ICP-MS, inductively coupled plasma- mass spectrometry; cICP-MS, cell inductively coupled plasma-mass spectrometry; HPLC/MS-MS, high performance liquid chromatography-tandem mass spectrometry; HCO3, bicarbonate; $\mu \mathrm{S} / \mathrm{cm}$, microsiemens per centimeter; $\mu \mathrm{g} / \mathrm{L}$, micrograms per liter; $\mathrm{mg} / \mathrm{L}$, milligrams per liter; ng/L, nanograms per liter; DAI-LC/MS-MS, direct aqueous injection-liquid chromatography/tandem mass spectrometry; ICP-OES, inductively coupled plasma-optical emission spectrometry; IC, ion chromatography; GCM66, ambient purgeable method (GC/MS); GM016, heat purgeable method (GC/MS); GC/MS-MS, gas chromatography, tandem mass spectrometry; LC/MS-MS, liquid chromatography-tandem mass spectrometry; ELISA, enzyme linked immunosorbent assay for algal toxins; MDL, method detection limit; MRL, minimum reporting level; IRL, interim reporting level; LOQ, limit of quantification; RLDQC, reporting limit by (DQCALC)]

\begin{tabular}{|c|c|c|c|c|c|c|}
\hline $\begin{array}{c}\text { NWIS } \\
\text { Parameter } \\
\text { code }\end{array}$ & $\begin{array}{l}\text { Laboratory } \\
\text { method code }\end{array}$ & $\begin{array}{c}\text { Reporting } \\
\text { limit }^{1} \\
(2016)\end{array}$ & $\begin{array}{c}\text { Reporting } \\
\text { limit }^{1} \\
(2017)\end{array}$ & Units & $\begin{array}{c}\text { Method of } \\
\text { quantitation }\end{array}$ & Reference cited \\
\hline 51863 & LC/MS-MS & 3.50 & 3.50 & $\mathrm{ng} / \mathrm{L}$ & MDL & $\begin{array}{l}\text { Hladik and Calhoun, } 2012 \\
\text { (additional compound) }\end{array}$ \\
\hline 52769 & LC/MS-MS & NA & 3.20 & $\mathrm{ng} / \mathrm{L}$ & MDL & $\begin{array}{l}\text { Hladik and Calhoun, } 2012 \\
\text { (additional compound) }\end{array}$ \\
\hline 68692 & LC/MS-MS & NA & 3.00 & $\mathrm{ng} / \mathrm{L}$ & MDL & $\begin{array}{c}\text { Hladik and Calhoun, } 2012 \\
\text { (additional compound) }\end{array}$ \\
\hline 67161 & LC/MS-MS & 3.60 & 3.60 & $\mathrm{ng} / \mathrm{L}$ & MDL & $\begin{array}{l}\text { Hladik and Calhoun, } 2012 \\
\text { (additional compound) }\end{array}$ \\
\hline 68485 & LC/MS-MS & 3.20 & 3.20 & $\mathrm{ng} / \mathrm{L}$ & MDL & Hladik and Calhoun, 2012 \\
\hline 51866 & LC/MS-MS & 2.90 & 2.90 & $\mathrm{ng} / \mathrm{L}$ & MDL & $\begin{array}{l}\text { Hladik and Calhoun, } 2012 \\
\text { (additional compound) }\end{array}$ \\
\hline 52768 & LC/MS-MS & NA & 4.10 & $\mathrm{ng} / \mathrm{L}$ & MDL & $\begin{array}{c}\text { Hladik and Calhoun, } 2012 \\
\text { (additional compound) }\end{array}$ \\
\hline 52765 & LC/MS-MS & NA & 4.50 & $\mathrm{ng} / \mathrm{L}$ & MDL & $\begin{array}{c}\text { Hladik and Calhoun, } 2012 \\
\text { (additional compound) }\end{array}$ \\
\hline 68360 & GC/MS & 1.9 & 1.9 & $\mathrm{ng} / \mathrm{L}$ & MDL & $\begin{array}{l}\text { Hladik and others, } 2008 \\
\quad \text { (additional compound) }\end{array}$ \\
\hline 67446 & LC/MS-MS & 87.7 & 88.0 & $\mathrm{ng} / \mathrm{L}$ & RLDQC & Furlong and others, 2014 \\
\hline 68250 & LC/MS-MS & 21.3 & 21.0 & $\mathrm{ng} / \mathrm{L}$ & RLDQC & Furlong and others, 2014 \\
\hline 67522 & LC/MS-MS & 37.2 & 37.0 & $\mathrm{ng} / \mathrm{L}$ & RLDQC & Furlong and others, 2014 \\
\hline 67461 & LC/MS-MS & 8.14 & 8.10 & $\mathrm{ng} / \mathrm{L}$ & RLDQC & Furlong and others, 2014 \\
\hline 67477 & LC/MS-MS & 116 & 116 & $\mathrm{ng} / \mathrm{L}$ & RLDQC & Furlong and others, 2014 \\
\hline 67502 & LC/MS-MS & 13.3 & 13.0 & $\mathrm{ng} / \mathrm{L}$ & RLDQC & Furlong and others, 2014 \\
\hline 65065 & LC/MS-MS & 19.4 & 19.0 & $\mathrm{ng} / \mathrm{L}$ & RLDQC & Furlong and others, 2014 \\
\hline 67997 & LC/MS-MS & 24.0 & 44.0 & $\mathrm{ng} / \mathrm{L}$ & RLDQC & Furlong and others, 2014 \\
\hline 67485 & LC/MS-MS & 114 & 114 & $\mathrm{ng} / \mathrm{L}$ & RLDQC & Furlong and others, 2014 \\
\hline 67439 & LC/MS-MS & 17.8 & 18.0 & $\mathrm{ng} / \mathrm{L}$ & RLDQC & Furlong and others, 2014 \\
\hline
\end{tabular}


Table 2. Chemical compound information for analyses performed by various laboratories for the U.S. Geological Survey, Environmental Health Mission Area, Infrastructure Project, Tapwater Exposure Pilot Study, 2016-17._Continued

[NWIS, National Water Information System; CAS, Chemical Abstract Services; y, year; NA, not available; EPA, U.S. Environmental Protection Agency; RED01, enzyme reduction-diazotization; GC, gas chromatograph; LC, liquid chromatography; ICP-MS, inductively coupled plasma-mass spectrometry; cICP-MS, cell inductively coupled plasma-mass spectrometry; HPLC/MS-MS, high performance liquid chromatography/tandem mass spectrometry; HCO3, bicarbonate; $\mu \mathrm{S} / \mathrm{cm}$, microsiemens per centimeter; $\mu \mathrm{g} / \mathrm{L}$, micrograms per liter; $\mathrm{mg} / \mathrm{L}$, milligrams per liter; ng/L, nanograms per liter; DAI-LC/MS-MS, direct aqueous injection-liquid chromatography/tandem mass spectrometry; ICP-OES, inductively coupled plasma-optical emission spectrometry; IC, ion chromatography; GCM66, ambient purgeable method (GC/MS); GM016, heat purgeable method (GC/MS); GC/MS-MS, gas chromatography/tandem mass spectrometry; LC/MS-MS, liquid chromatography-tandem mass spectrometry; ELISA, enzyme linked immunosorbent assay for algal toxins; MDL, method detection limit; MRL, minimum reporting level; IRL, interim reporting level; LOQ, limit of quantification; RLDQC, reporting limit by (DQCALC)]

\begin{tabular}{|c|c|c|c|c|}
\hline Compound & CAS number & Compound class & $\begin{array}{c}\text { Year } \\
\text { collected } \\
\text { (yyyy) }\end{array}$ & Analyzing laboratory \\
\hline Caffeine & $58-08-2$ & Pharmaceutically active and other & 2016 and 2017 & National Water Quality Laboratory \\
\hline Carbamazepine & $298-46-4$ & Pharmaceutically active and other & 2016 and 2017 & National Water Quality Laboratory \\
\hline Carisoprodol & $78-44-4$ & Pharmaceutically active and other & 2016 and 2017 & National Water Quality Laboratory \\
\hline Chlorpheniramine & $132-22-9$ & Pharmaceutically active and other & 2016 and 2017 & National Water Quality Laboratory \\
\hline Citalopram & $59729-33-8$ & Pharmaceutically active and other & 2016 and 2017 & National Water Quality Laboratory \\
\hline Clonidine & $4205-90-7$ & Pharmaceutically active and other & 2016 and 2017 & National Water Quality Laboratory \\
\hline Codeine & $76-57-3$ & Pharmaceutically active and other & 2016 and 2017 & National Water Quality Laboratory \\
\hline Cotinine & $486-56-6$ & Pharmaceutically active and other & 2016 and 2017 & National Water Quality Laboratory \\
\hline Dextromethorphan & $125-71-3$ & Pharmaceutically active and other & 2016 and 2017 & National Water Quality Laboratory \\
\hline Diazepam (valium) & $439-14-5$ & Pharmaceutically active and other & 2016 and 2017 & National Water Quality Laboratory \\
\hline Diltiazem & $42399-41-7$ & Pharmaceutically active and other & 2016 and 2017 & National Water Quality Laboratory \\
\hline Diphenhydramine & $147-24-0$ & Pharmaceutically active and other & 2016 and 2017 & National Water Quality Laboratory \\
\hline Duloxetine & $116539-59-4$ & Pharmaceutically active and other & 2016 and 2017 & National Water Quality Laboratory \\
\hline Erythromycin & $114-07-8$ & Pharmaceutically active and other & 2016 and 2017 & National Water Quality Laboratory \\
\hline Ezetimibe & $163222-33-1$ & Pharmaceutically active and other & 2016 and 2017 & National Water Quality Laboratory \\
\hline Fadrozole & $102676-47-1$ & Pharmaceutically active and other & 2016 and 2017 & National Water Quality Laboratory \\
\hline Famotidine & $76824-35-6$ & Pharmaceutically active and other & 2016 and 2017 & National Water Quality Laboratory \\
\hline Gabapentin & $60142-96-3$ & Pharmaceutically active and other & 2016 and 2017 & National Water Quality Laboratory \\
\hline Glipizide & 29094-61-9 & Pharmaceutically active and other & 2016 and 2017 & National Water Quality Laboratory \\
\hline Glyburide & $10238-21-8$ & Pharmaceutically active and other & 2016 and 2017 & National Water Quality Laboratory \\
\hline Guanylurea & $141-83-3$ & Pharmaceutically active and other & 2016 and 2017 & National Water Quality Laboratory \\
\hline Hexamethylenetetramine & $100-97-0$ & Pharmaceutically active and other & 2016 and 2017 & National Water Quality Laboratory \\
\hline Hydrocodone & $125-29-1$ & Pharmaceutically active and other & 2016 and 2017 & National Water Quality Laboratory \\
\hline Hydrocortisone & $50-23-7$ & Pharmaceutically active and other & 2016 and 2017 & National Water Quality Laboratory \\
\hline Hydroxyzine & $68-88-2$ & Pharmaceutically active and other & 2016 and 2017 & National Water Quality Laboratory \\
\hline
\end{tabular}


Table 2. Chemical compound information for analyses performed by various laboratories for the U.S. Geological Survey, Environmental Health Mission Area, Infrastructure Project, Tapwater Exposure Pilot Study, 2016-17. —Continued

[NWIS, National Water Information System; CAS, Chemical Abstract Services; y, year; NA, not available; EPA, U.S. Environmental Protection Agency; RED01, enzyme reduction-diazotization; GC, gas chromatograph; LC, liquid chromatography; ICP-MS, inductively coupled plasma- mass spectrometry; cICP-MS, cell inductively coupled plasma-mass spectrometry; HPLC/MS-MS, high performance liquid chromatography-tandem mass spectrometry; HCO3, bicarbonate; $\mu \mathrm{S} / \mathrm{cm}$, microsiemens per centimeter; $\mu \mathrm{g} / \mathrm{L}$, micrograms per liter; $\mathrm{mg} / \mathrm{L}$, milligrams per liter; ng/L, nanograms per liter; DAI-LC/MS-MS, direct aqueous injection-liquid chromatography/tandem mass spectrometry; ICP-OES, inductively coupled plasma-optical emission spectrometry; IC, ion chromatography; GCM66, ambient purgeable method (GC/MS); GM016, heat purgeable method (GC/MS); GC/MS-MS, gas chromatography, tandem mass spectrometry; LC/MS-MS, liquid chromatography-tandem mass spectrometry; ELISA, enzyme linked immunosorbent assay for algal toxins; MDL, method detection limit; MRL, minimum reporting level; IRL, interim reporting level; LOQ, limit of quantification; RLDQC, reporting limit by (DQCALC)]

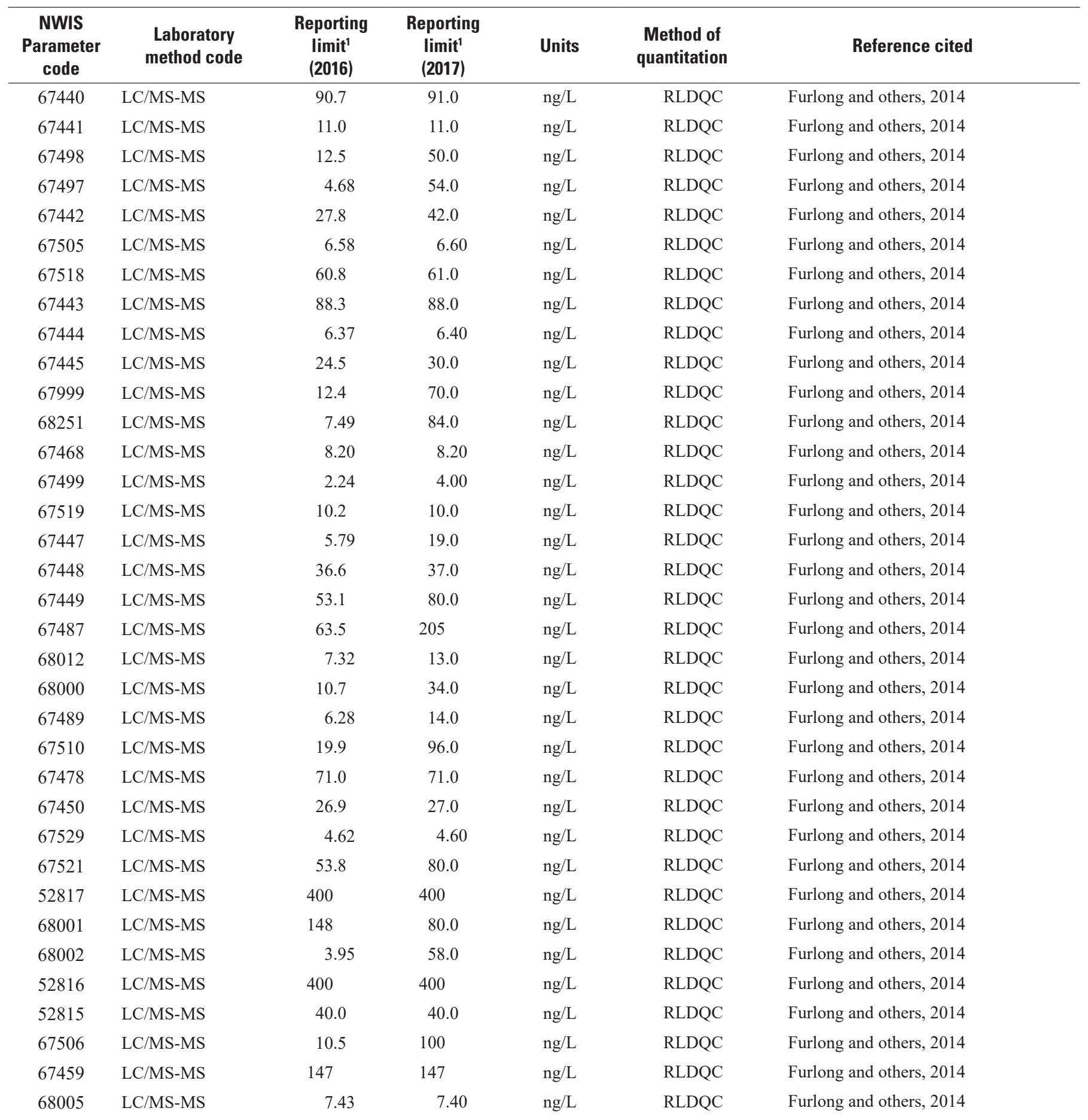


Table 2. Chemical compound information for analyses performed by various laboratories for the U.S. Geological Survey, Environmental Health Mission Area, Infrastructure Project, Tapwater Exposure Pilot Study, 2016-17.-Continued

[NWIS, National Water Information System; CAS, Chemical Abstract Services; y, year; NA, not available; EPA, U.S. Environmental Protection Agency; RED01, enzyme reduction-diazotization; GC, gas chromatograph; LC, liquid chromatography; ICP-MS, inductively coupled plasma-mass spectrometry; cICP-MS, cell inductively coupled plasma-mass spectrometry; HPLC/MS-MS, high performance liquid chromatography/tandem mass spectrometry; HCO3, bicarbonate; $\mu \mathrm{S} / \mathrm{cm}$, microsiemens per centimeter; $\mu \mathrm{g} / \mathrm{L}$, micrograms per liter; $\mathrm{mg} / \mathrm{L}$, milligrams per liter; ng/L, nanograms per liter; DAI-LC/MS-MS, direct aqueous injection-liquid chromatography/tandem mass spectrometry; ICP-OES, inductively coupled plasma-optical emission spectrometry; IC, ion chromatography; GCM66, ambient purgeable method (GC/MS); GM016, heat purgeable method (GC/MS); GC/MS-MS, gas chromatography/tandem mass spectrometry; LC/MS-MS, liquid chromatography-tandem mass spectrometry; ELISA, enzyme linked immunosorbent assay for algal toxins; MDL, method detection limit; MRL, minimum reporting level; IRL, interim reporting level; LOQ, limit of quantification; RLDQC, reporting limit by (DQCALC)]

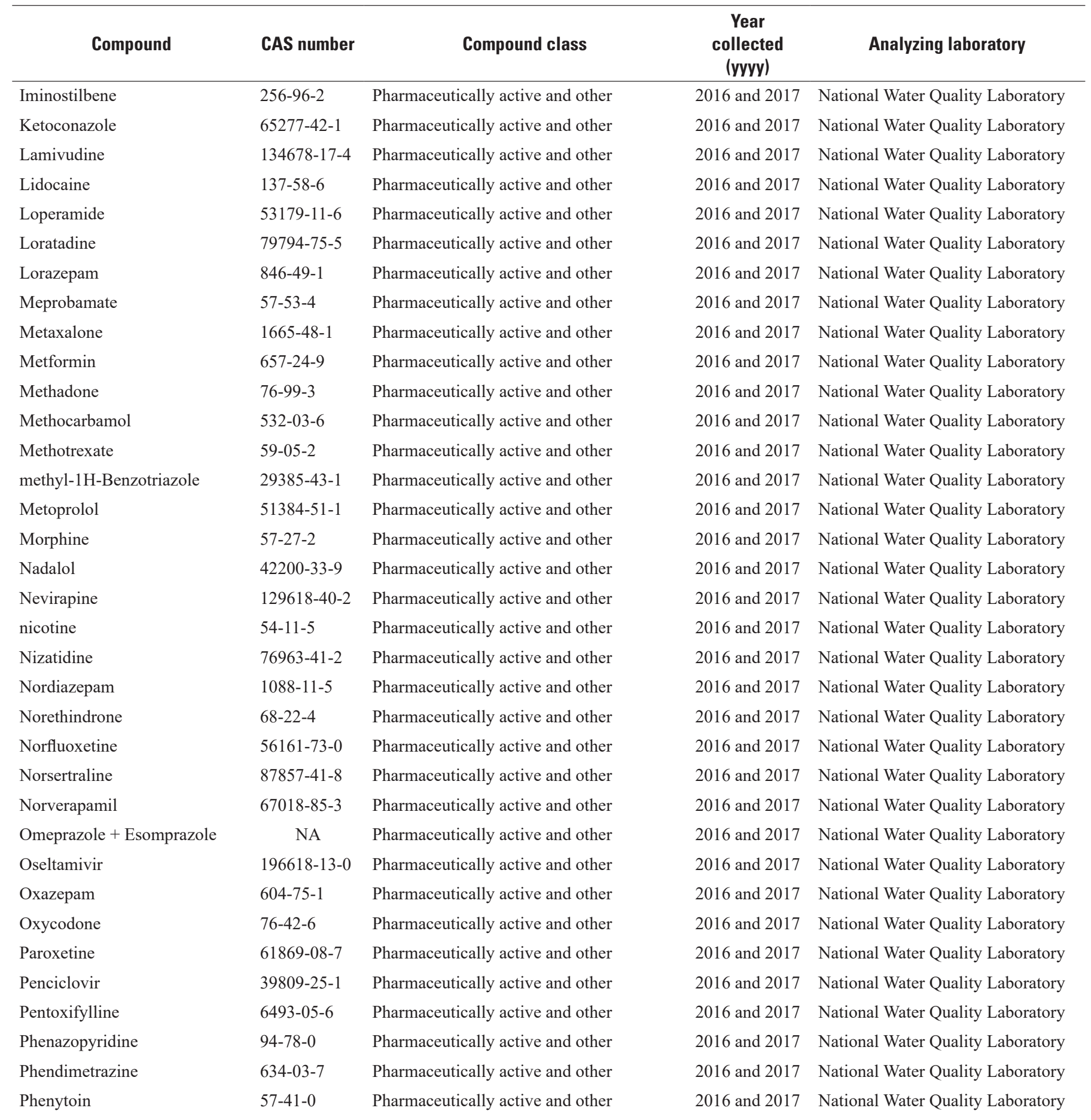


Table 2. 51

Table 2. Chemical compound information for analyses performed by various laboratories for the U.S. Geological Survey, Environmental Health Mission Area, Infrastructure Project, Tapwater Exposure Pilot Study, 2016-17. —Continued

[NWIS, National Water Information System; CAS, Chemical Abstract Services; y, year; NA, not available; EPA, U.S. Environmental Protection Agency; RED01, enzyme reduction-diazotization; GC, gas chromatograph; LC, liquid chromatography; ICP-MS, inductively coupled plasma- mass spectrometry; cICP-MS, cell inductively coupled plasma-mass spectrometry; HPLC/MS-MS, high performance liquid chromatography-tandem mass spectrometry; HCO3, bicarbonate; $\mu \mathrm{S} / \mathrm{cm}$, microsiemens per centimeter; $\mu \mathrm{g} / \mathrm{L}$, micrograms per liter; mg/L, milligrams per liter; ng/L, nanograms per liter; DAI-LC/MS-MS, direct aqueous injection-liquid chromatography/tandem mass spectrometry; ICP-OES, inductively coupled plasma-optical emission spectrometry; IC, ion chromatography; GCM66, ambient purgeable method (GC/MS); GM016, heat purgeable method (GC/MS); GC/MS-MS, gas chromatography, tandem mass spectrometry; LC/MS-MS, liquid chromatography-tandem mass spectrometry; ELISA, enzyme linked immunosorbent assay for algal toxins; MDL, method detection limit; MRL, minimum reporting level; IRL, interim reporting level; LOQ, limit of quantification; RLDQC, reporting limit by (DQCALC)]

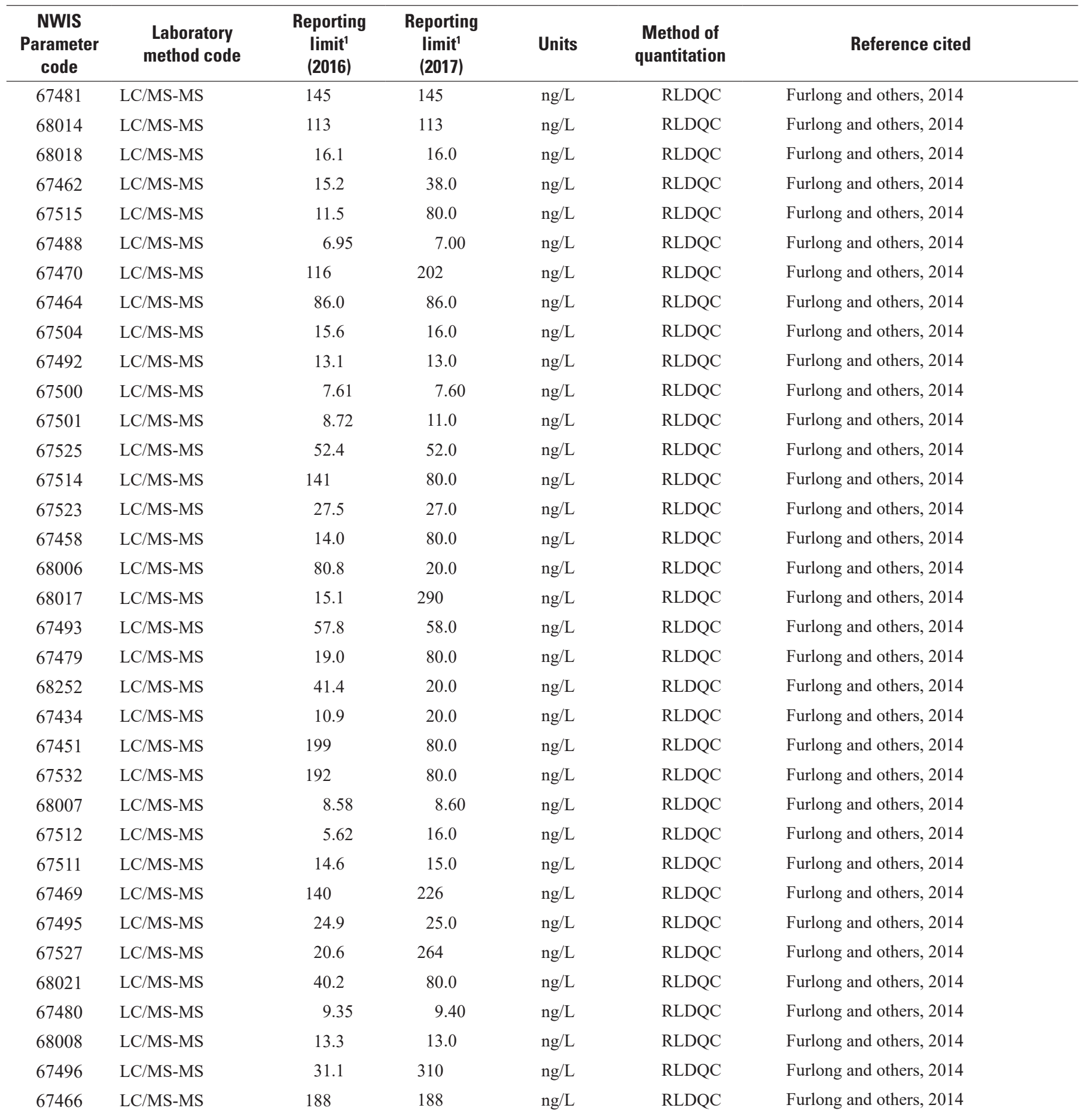


Table 2. Chemical compound information for analyses performed by various laboratories for the U.S. Geological Survey, Environmental Health Mission Area, Infrastructure Project, Tapwater Exposure Pilot Study, 2016-17.-Continued

[NWIS, National Water Information System; CAS, Chemical Abstract Services; y, year; NA, not available; EPA, U.S. Environmental Protection Agency; RED01, enzyme reduction-diazotization; GC, gas chromatograph; LC, liquid chromatography; ICP-MS, inductively coupled plasma-mass spectrometry; cICP-MS, cell inductively coupled plasma-mass spectrometry; HPLC/MS-MS, high performance liquid chromatography/tandem mass spectrometry; HCO3, bicarbonate; $\mu \mathrm{S} / \mathrm{cm}$, microsiemens per centimeter; $\mu \mathrm{g} / \mathrm{L}$, micrograms per liter; $\mathrm{mg} / \mathrm{L}$, milligrams per liter; ng/L, nanograms per liter; DAI-LC/MS-MS, direct aqueous injection-liquid chromatography/tandem mass spectrometry; ICP-OES, inductively coupled plasma-optical emission spectrometry; IC, ion chromatography; GCM66, ambient purgeable method (GC/MS); GM016, heat purgeable method (GC/MS); GC/MS-MS, gas chromatography/tandem mass spectrometry; LC/MS-MS, liquid chromatography-tandem mass spectrometry; ELISA, enzyme linked immunosorbent assay for algal toxins; MDL, method detection limit; MRL, minimum reporting level; IRL, interim reporting level; LOQ, limit of quantification; RLDQC, reporting limit by (DQCALC)]

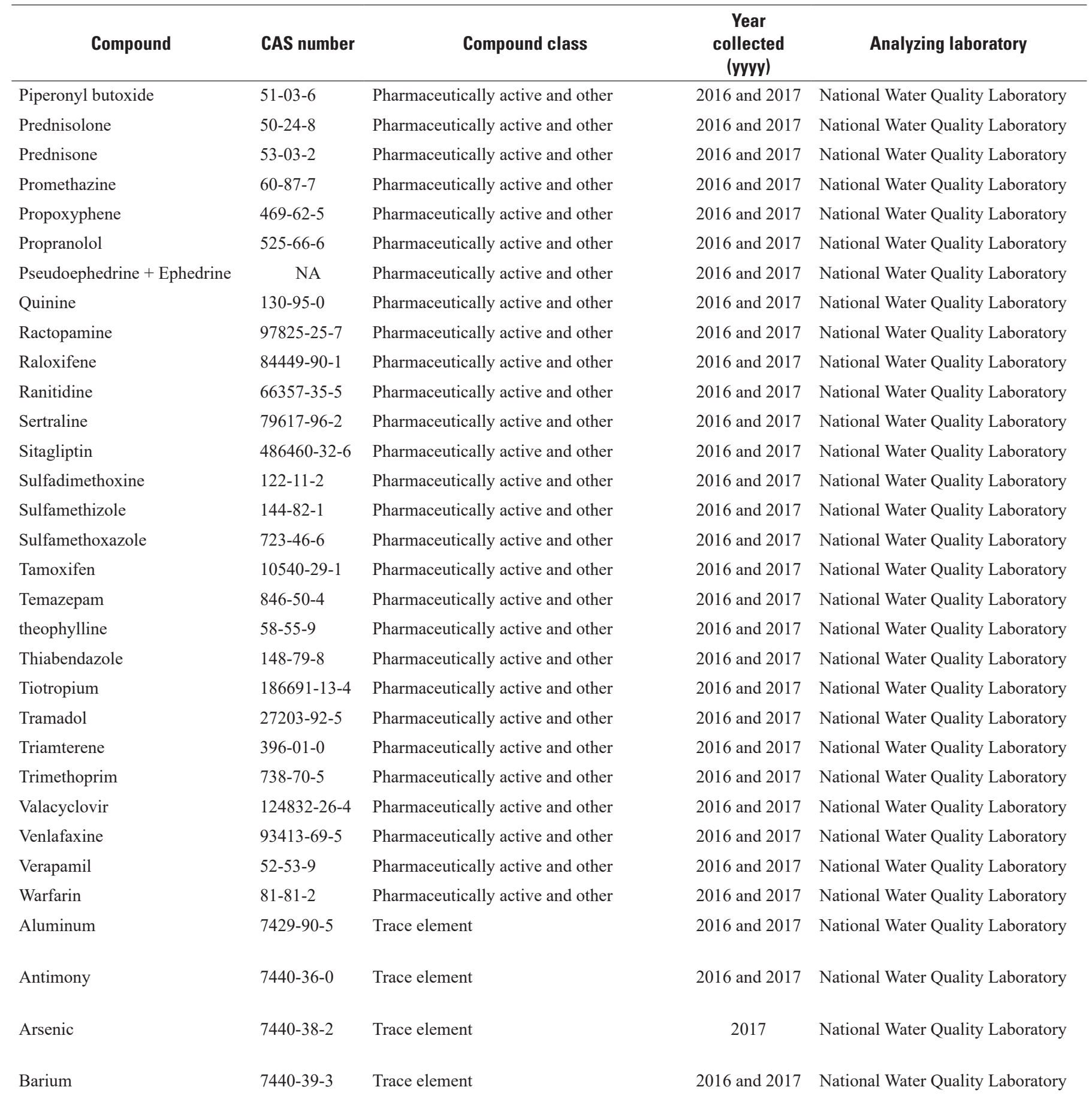


Table 2. Chemical compound information for analyses performed by various laboratories for the U.S. Geological Survey, Environmental Health Mission Area, Infrastructure Project, Tapwater Exposure Pilot Study, 2016-17. —Continued

[NWIS, National Water Information System; CAS, Chemical Abstract Services; y, year; NA, not available; EPA, U.S. Environmental Protection Agency; RED01, enzyme reduction-diazotization; GC, gas chromatograph; LC, liquid chromatography; ICP-MS, inductively coupled plasma- mass spectrometry; cICP-MS, cell inductively coupled plasma-mass spectrometry; HPLC/MS-MS, high performance liquid chromatography-tandem mass spectrometry; HCO3, bicarbonate; $\mu \mathrm{S} / \mathrm{cm}$, microsiemens per centimeter; $\mu \mathrm{g} / \mathrm{L}$, micrograms per liter; mg/L, milligrams per liter; ng/L, nanograms per liter; DAI-LC/MS-MS, direct aqueous injection-liquid chromatography/tandem mass spectrometry; ICP-OES, inductively coupled plasma-optical emission spectrometry; IC, ion chromatography; GCM66, ambient purgeable method (GC/MS); GM016, heat purgeable method (GC/MS); GC/MS-MS, gas chromatography, tandem mass spectrometry; LC/MS-MS, liquid chromatography-tandem mass spectrometry; ELISA, enzyme linked immunosorbent assay for algal toxins; MDL, method detection limit; MRL, minimum reporting level; IRL, interim reporting level; LOQ, limit of quantification; RLDQC, reporting limit by (DQCALC)]

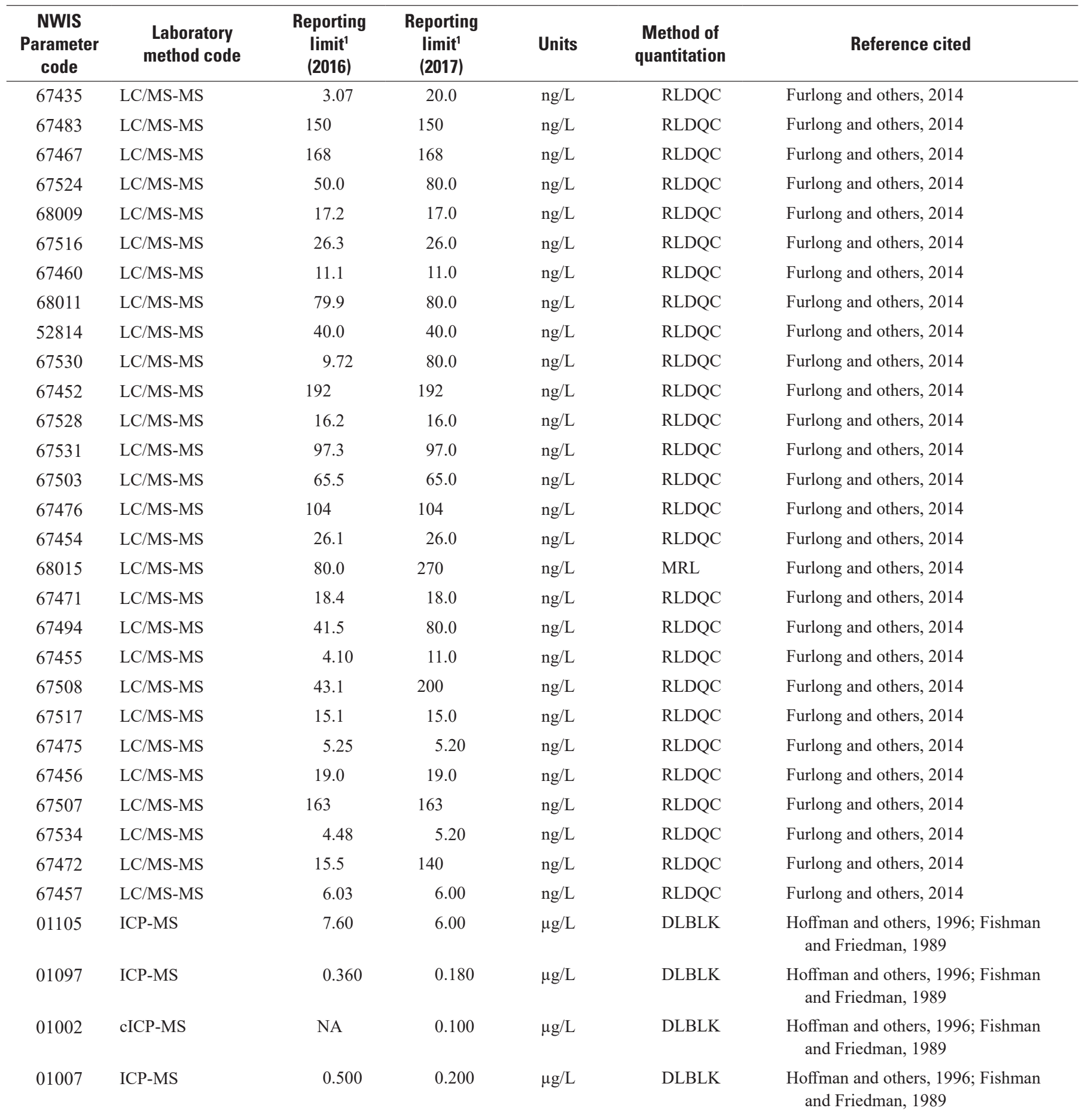


Table 2. Chemical compound information for analyses performed by various laboratories for the U.S. Geological Survey, Environmental Health Mission Area, Infrastructure Project, Tapwater Exposure Pilot Study, 2016-17.-Continued

[NWIS, National Water Information System; CAS, Chemical Abstract Services; y, year; NA, not available; EPA, U.S. Environmental Protection Agency; RED01, enzyme reduction-diazotization; GC, gas chromatograph; LC, liquid chromatography; ICP-MS, inductively coupled plasma-mass spectrometry; cICP-MS, cell inductively coupled plasma-mass spectrometry; HPLC/MS-MS, high performance liquid chromatography/tandem mass spectrometry; HCO3, bicarbonate; $\mu \mathrm{S} / \mathrm{cm}$, microsiemens per centimeter; $\mu \mathrm{g} / \mathrm{L}$, micrograms per liter; $\mathrm{mg} / \mathrm{L}$, milligrams per liter; ng/L, nanograms per liter; DAI-LC/MS-MS, direct aqueous injection-liquid chromatography/tandem mass spectrometry; ICP-OES, inductively coupled plasma-optical emission spectrometry; IC, ion chromatography; GCM66, ambient purgeable method (GC/MS); GM016, heat purgeable method (GC/MS); GC/MS-MS, gas chromatography/tandem mass spectrometry; LC/MS-MS, liquid chromatography-tandem mass spectrometry; ELISA, enzyme linked immunosorbent assay for algal toxins; MDL, method detection limit; MRL, minimum reporting level; IRL, interim reporting level; LOQ, limit of quantification; RLDQC, reporting limit by (DQCALC)]

\begin{tabular}{|c|c|c|c|c|}
\hline Compound & CAS number & Compound class & $\begin{array}{c}\text { Year } \\
\text { collected } \\
\text { (yyyy) }\end{array}$ & Analyzing laboratory \\
\hline Beryllium & $7440-41-7$ & Trace element & 2016 and 2017 & National Water Quality Laboratory \\
\hline Boron & $7440-42-8$ & Trace element & 2017 & National Water Quality Laboratory \\
\hline Calcium & $7440-70-2$ & Trace element & 2017 & National Water Quality Laboratory \\
\hline Chromium & $7440-47-3$ & Trace element & 2016 and 2017 & National Water Quality Laboratory \\
\hline Cobalt & $7440-48-4$ & Trace element & 2016 and 2017 & National Water Quality Laboratory \\
\hline Iron & $7439-89-6$ & Trace element & 2017 & National Water Quality Laboratory \\
\hline Lead & $7439-92-1$ & Trace element & 2016 and 2017 & National Water Quality Laboratory \\
\hline Lithium & $7439-93-2$ & Trace element & 2016 and 2017 & National Water Quality Laboratory \\
\hline Magnesium & $7439-95-4$ & Trace element & 2017 & National Water Quality Laboratory \\
\hline Manganese & $7439-96-5$ & Trace element & 2016 and 2017 & National Water Quality Laboratory \\
\hline Selenium & $7782-49-2$ & Trace element & 2016 and 2017 & National Water Quality Laboratory \\
\hline Silica & $7631-86-9$ & Trace element & 2017 & National Water Quality Laboratory \\
\hline Silver & $7440-22-4$ & Trace element & 2016 and 2017 & National Water Quality Laboratory \\
\hline Sodium & $7440-23-5$ & Trace element & 2017 & National Water Quality Laboratory \\
\hline $\begin{array}{l}\text { specific conductance, } \\
\text { laboratory }\end{array}$ & NA & NA & 2016 and 2017 & National Water Quality Laboratory \\
\hline
\end{tabular}


Table 2. Chemical compound information for analyses performed by various laboratories for the U.S. Geological Survey, Environmental Health Mission Area, Infrastructure Project, Tapwater Exposure Pilot Study, 2016-17. —Continued

[NWIS, National Water Information System; CAS, Chemical Abstract Services; y, year; NA, not available; EPA, U.S. Environmental Protection Agency; RED01, enzyme reduction-diazotization; GC, gas chromatograph; LC, liquid chromatography; ICP-MS, inductively coupled plasma- mass spectrometry; cICP-MS, cell inductively coupled plasma-mass spectrometry; HPLC/MS-MS, high performance liquid chromatography-tandem mass spectrometry; HCO3, bicarbonate; $\mu \mathrm{S} / \mathrm{cm}$, microsiemens per centimeter; $\mu \mathrm{g} / \mathrm{L}$, micrograms per liter; $\mathrm{mg} / \mathrm{L}$, milligrams per liter; ng/L, nanograms per liter; DAI-LC/MS-MS, direct aqueous injection-liquid chromatography/tandem mass spectrometry; ICP-OES, inductively coupled plasma-optical emission spectrometry; IC, ion chromatography; GCM66, ambient purgeable method (GC/MS); GM016, heat purgeable method (GC/MS); GC/MS-MS, gas chromatography, tandem mass spectrometry; LC/MS-MS, liquid chromatography-tandem mass spectrometry; ELISA, enzyme linked immunosorbent assay for algal toxins; MDL, method detection limit; MRL, minimum reporting level; IRL, interim reporting level; LOQ, limit of quantification; RLDQC, reporting limit by (DQCALC)]

\begin{tabular}{|c|c|c|c|c|c|c|}
\hline $\begin{array}{c}\text { NWIS } \\
\text { Parameter } \\
\text { code }\end{array}$ & $\begin{array}{l}\text { Laboratory } \\
\text { method code }\end{array}$ & $\begin{array}{c}\text { Reporting } \\
\text { limit }^{1} \\
(2016)\end{array}$ & $\begin{array}{c}\text { Reporting } \\
\text { limit }^{1} \\
(2017)\end{array}$ & Units & $\begin{array}{l}\text { Method of } \\
\text { quantitation }\end{array}$ & Reference cited \\
\hline 01012 & ICP-MS & 0.040 & 0.020 & $\mu \mathrm{g} / \mathrm{L}$ & DLBLK & $\begin{array}{l}\text { Hoffman and others, 1996; Fishman } \\
\text { and Friedman, } 1989\end{array}$ \\
\hline 01022 & ICP-MS & NA & 10.0 & $\mu \mathrm{g} / \mathrm{L}$ & DLBLK & $\begin{array}{l}\text { Hoffman and others, 1996; Fishman } \\
\text { and Friedman, } 1989\end{array}$ \\
\hline 00916 & ICP & NA & 0.042 & $\mathrm{mg} / \mathrm{L}$ & DLDQC & $\begin{array}{l}\text { Hoffman and others, 1996; Fishman } \\
\text { and Friedman, } 1989\end{array}$ \\
\hline 01034 & cICP-MS & 0.800 & 1.00 & $\mu \mathrm{g} / \mathrm{L}$ & DLBLK & $\begin{array}{l}\text { Hoffman and others, 1996; Fishman } \\
\text { and Friedman, } 1989\end{array}$ \\
\hline 01037 & cICP-MS & 0.100 & 0.060 & $\mu \mathrm{g} / \mathrm{L}$ & DLBLK & $\begin{array}{l}\text { Hoffman and others, 1996; Fishman } \\
\text { and Friedman, } 1989\end{array}$ \\
\hline 01045 & $\mathrm{ICP}$ & NA & 20.0 & $\mu \mathrm{g} / \mathrm{L}$ & DLDQC & $\begin{array}{l}\text { Hoffman and others, 1996; Fishman } \\
\text { and Friedman, } 1989\end{array}$ \\
\hline 01051 & ICP-MS & 0.080 & 0.040 & $\mu \mathrm{g} / \mathrm{L}$ & DLBLK & $\begin{array}{l}\text { Hoffman and others, 1996; Fishman } \\
\text { and Friedman, } 1989\end{array}$ \\
\hline 01132 & ICP-MS & 0.300 & 0.300 & $\mu \mathrm{g} / \mathrm{L}$ & DLBLK & $\begin{array}{l}\text { Hoffman and others, 1996; Fishman } \\
\text { and Friedman, } 1989\end{array}$ \\
\hline 00927 & ICP & NA & 0.020 & $\mathrm{mg} / \mathrm{L}$ & DLDQC & $\begin{array}{l}\text { Hoffman and others, 1996; Fishman } \\
\text { and Friedman, } 1989\end{array}$ \\
\hline 01055 & ICP-MS & 0.800 & 0.800 & $\mu \mathrm{g} / \mathrm{L}$ & DLBLK & $\begin{array}{l}\text { Hoffman and others, 1996; Fishman } \\
\text { and Friedman, } 1989\end{array}$ \\
\hline 00956 & ICP & NA & 0.036 & $\mathrm{mg} / \mathrm{L}$ & DLDQC & $\begin{array}{l}\text { Hoffman and others, 1996; Fishman } \\
\text { and Friedman, } 1989\end{array}$ \\
\hline 01077 & ICP-MS & 0.060 & 0.060 & $\mu \mathrm{g} / \mathrm{L}$ & DLBLK & $\begin{array}{l}\text { Hoffman and others, 1996; Fishman } \\
\text { and Friedman, } 1989\end{array}$ \\
\hline 00929 & $\mathrm{ICP}$ & NA & 0.120 & $\mathrm{mg} / \mathrm{L}$ & DLDQC & $\begin{array}{l}\text { Hoffman and others, 1996; Fishman } \\
\text { and Friedman, } 1989\end{array}$ \\
\hline 90095 & WHT03 & 5.00 & 5.00 & $\mathrm{uS} / \mathrm{cm}$ & MRL & $\begin{array}{l}\text { Hoffman and others, 1996; Fishman } \\
\text { and Friedman, } 1989\end{array}$ \\
\hline
\end{tabular}


Table 2. Chemical compound information for analyses performed by various laboratories for the U.S. Geological Survey, Environmental Health Mission Area, Infrastructure Project, Tapwater Exposure Pilot Study, 2016-17._Continued

[NWIS, National Water Information System; CAS, Chemical Abstract Services; y, year; NA, not available; EPA, U.S. Environmental Protection Agency; RED01, enzyme reduction-diazotization; GC, gas chromatograph; LC, liquid chromatography; ICP-MS, inductively coupled plasma-mass spectrometry; cICP-MS, cell inductively coupled plasma-mass spectrometry; HPLC/MS-MS, high performance liquid chromatography/tandem mass spectrometry; HCO3, bicarbonate; $\mu \mathrm{S} / \mathrm{cm}$, microsiemens per centimeter; $\mu \mathrm{g} / \mathrm{L}$, micrograms per liter; $\mathrm{mg} / \mathrm{L}$, milligrams per liter; ng/L, nanograms per liter; DAI-LC/MS-MS, direct aqueous injection-liquid chromatography/tandem mass spectrometry; ICP-OES, inductively coupled plasma-optical emission spectrometry; IC, ion chromatography; GCM66, ambient purgeable method (GC/MS); GM016, heat purgeable method (GC/MS); GC/MS-MS, gas chromatography/tandem mass spectrometry; LC/MS-MS, liquid chromatography-tandem mass spectrometry; ELISA, enzyme linked immunosorbent assay for algal toxins; MDL, method detection limit; MRL, minimum reporting level; IRL, interim reporting level; LOQ, limit of quantification; RLDQC, reporting limit by (DQCALC)]

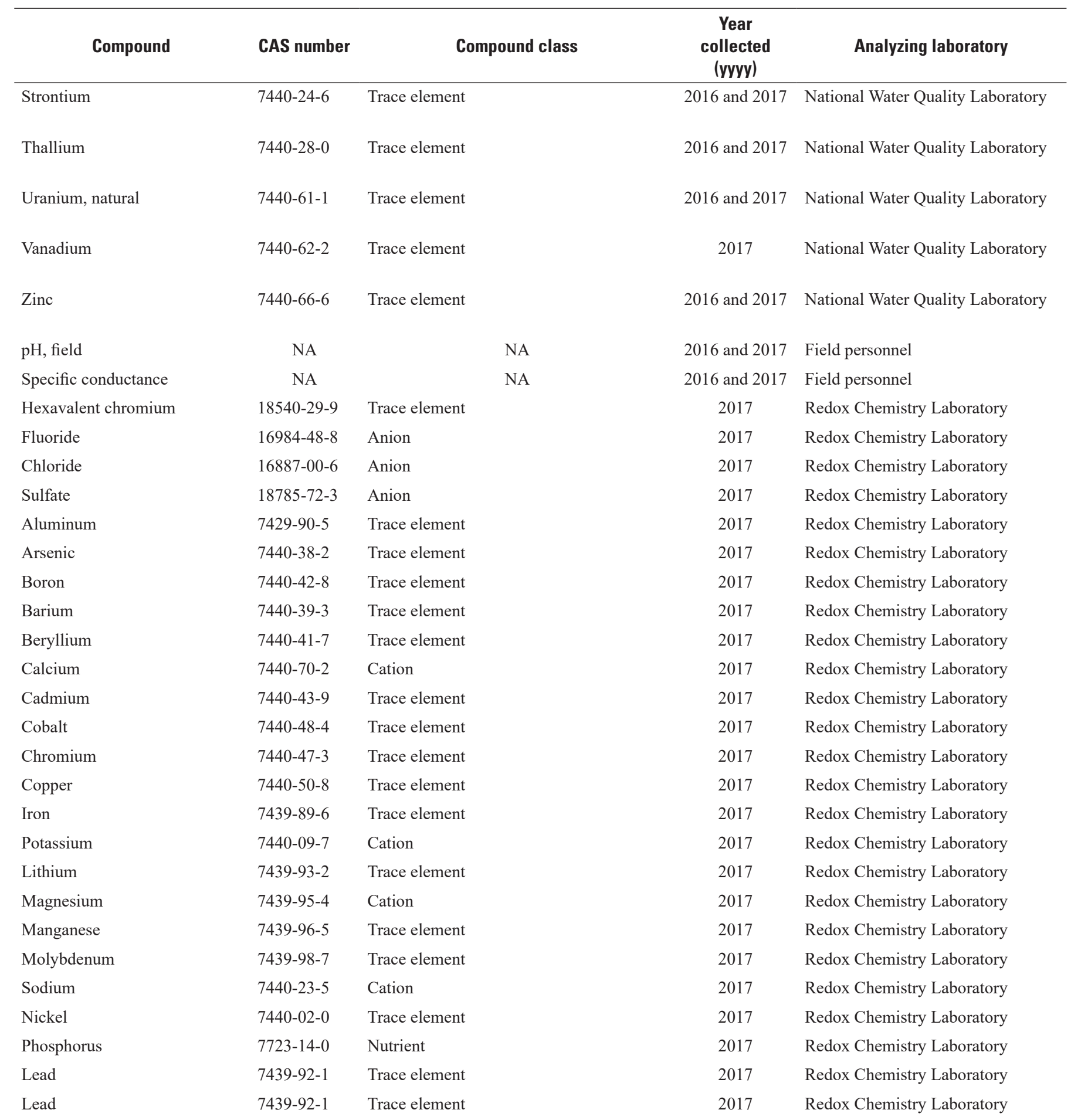


Table 2. Chemical compound information for analyses performed by various laboratories for the U.S. Geological Survey, Environmental Health Mission Area, Infrastructure Project, Tapwater Exposure Pilot Study, 2016-17. —Continued

[NWIS, National Water Information System; CAS, Chemical Abstract Services; y, year; NA, not available; EPA, U.S. Environmental Protection Agency; RED01, enzyme reduction-diazotization; GC, gas chromatograph; LC, liquid chromatography; ICP-MS, inductively coupled plasma- mass spectrometry; cICP-MS, cell inductively coupled plasma-mass spectrometry; HPLC/MS-MS, high performance liquid chromatography-tandem mass spectrometry; HCO3, bicarbonate; $\mu \mathrm{S} / \mathrm{cm}$, microsiemens per centimeter; $\mu \mathrm{g} / \mathrm{L}$, micrograms per liter; mg/L, milligrams per liter; ng/L, nanograms per liter; DAI-LC/MS-MS, direct aqueous injection-liquid chromatography/tandem mass spectrometry; ICP-OES, inductively coupled plasma-optical emission spectrometry; IC, ion chromatography; GCM66, ambient purgeable method (GC/MS); GM016, heat purgeable method (GC/MS); GC/MS-MS, gas chromatography, tandem mass spectrometry; LC/MS-MS, liquid chromatography-tandem mass spectrometry; ELISA, enzyme linked immunosorbent assay for algal toxins; MDL, method detection limit; MRL, minimum reporting level; IRL, interim reporting level; LOQ, limit of quantification; RLDQC, reporting limit by (DQCALC)]

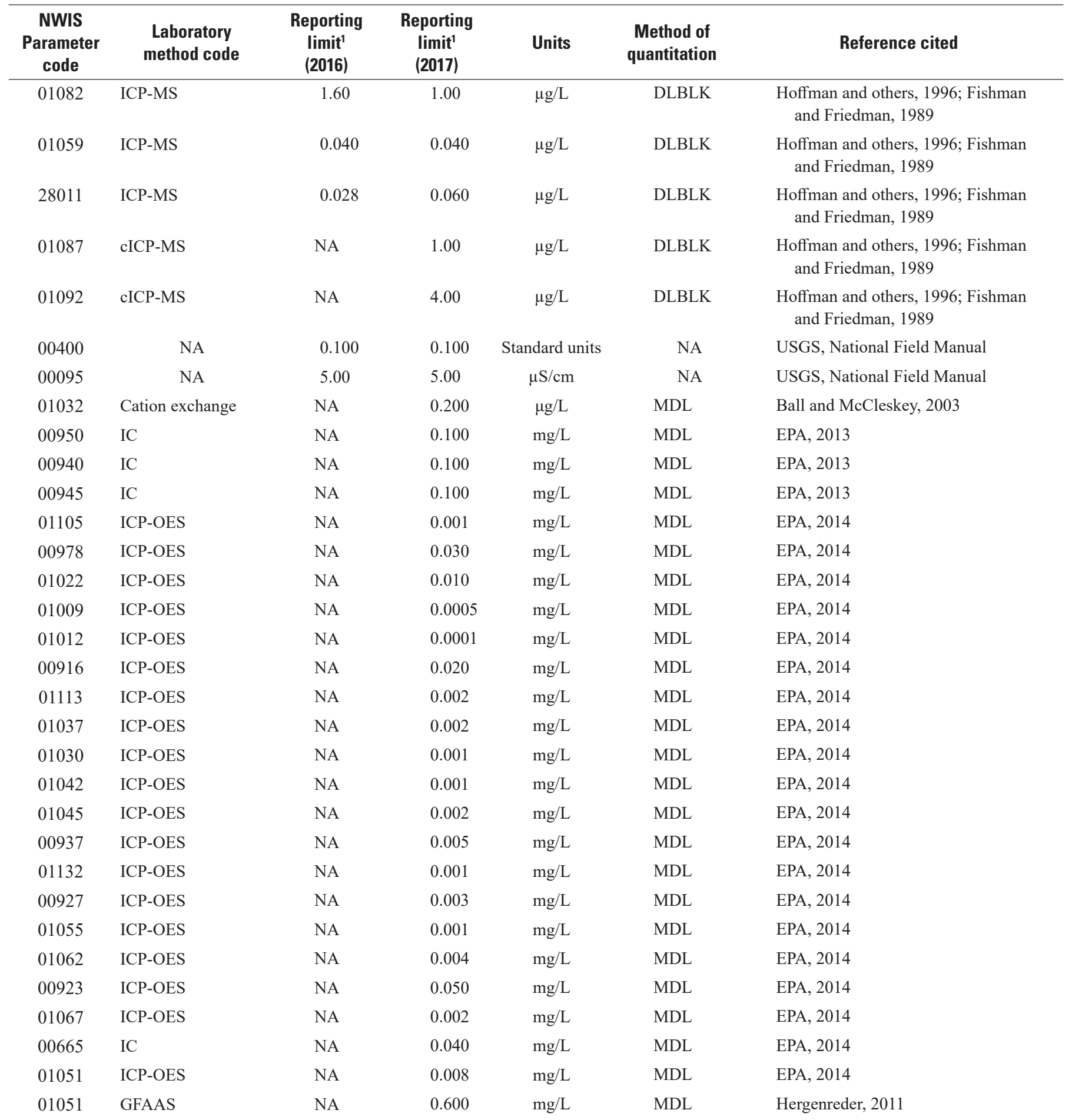


Table 2. Chemical compound information for analyses performed by various laboratories for the U.S. Geological Survey, Environmental Health Mission Area, Infrastructure Project, Tapwater Exposure Pilot Study, 2016-17.-Continued

[NWIS, National Water Information System; CAS, Chemical Abstract Services; y, year; NA, not available; EPA, U.S. Environmental Protection Agency; RED01, enzyme reduction-diazotization; GC, gas chromatograph; LC, liquid chromatography; ICP-MS, inductively coupled plasma-mass spectrometry; cICP-MS, cell inductively coupled plasma-mass spectrometry; HPLC/MS-MS, high performance liquid chromatography/tandem mass spectrometry; HCO3, bicarbonate; $\mu \mathrm{S} / \mathrm{cm}$, microsiemens per centimeter; $\mu \mathrm{g} / \mathrm{L}$, micrograms per liter; $\mathrm{mg} / \mathrm{L}$, milligrams per liter; ng/L, nanograms per liter; DAI-LC/MS-MS, direct aqueous injection-liquid chromatography/tandem mass spectrometry; ICP-OES, inductively coupled plasma-optical emission spectrometry; IC, ion chromatography; GCM66, ambient purgeable method (GC/MS); GM016, heat purgeable method (GC/MS); GC/MS-MS, gas chromatography/tandem mass spectrometry; LC/MS-MS, liquid chromatography-tandem mass spectrometry; ELISA, enzyme linked immunosorbent assay for algal toxins; MDL, method detection limit; MRL, minimum reporting level; IRL, interim reporting level; LOQ, limit of quantification; RLDQC, reporting limit by (DQCALC)]

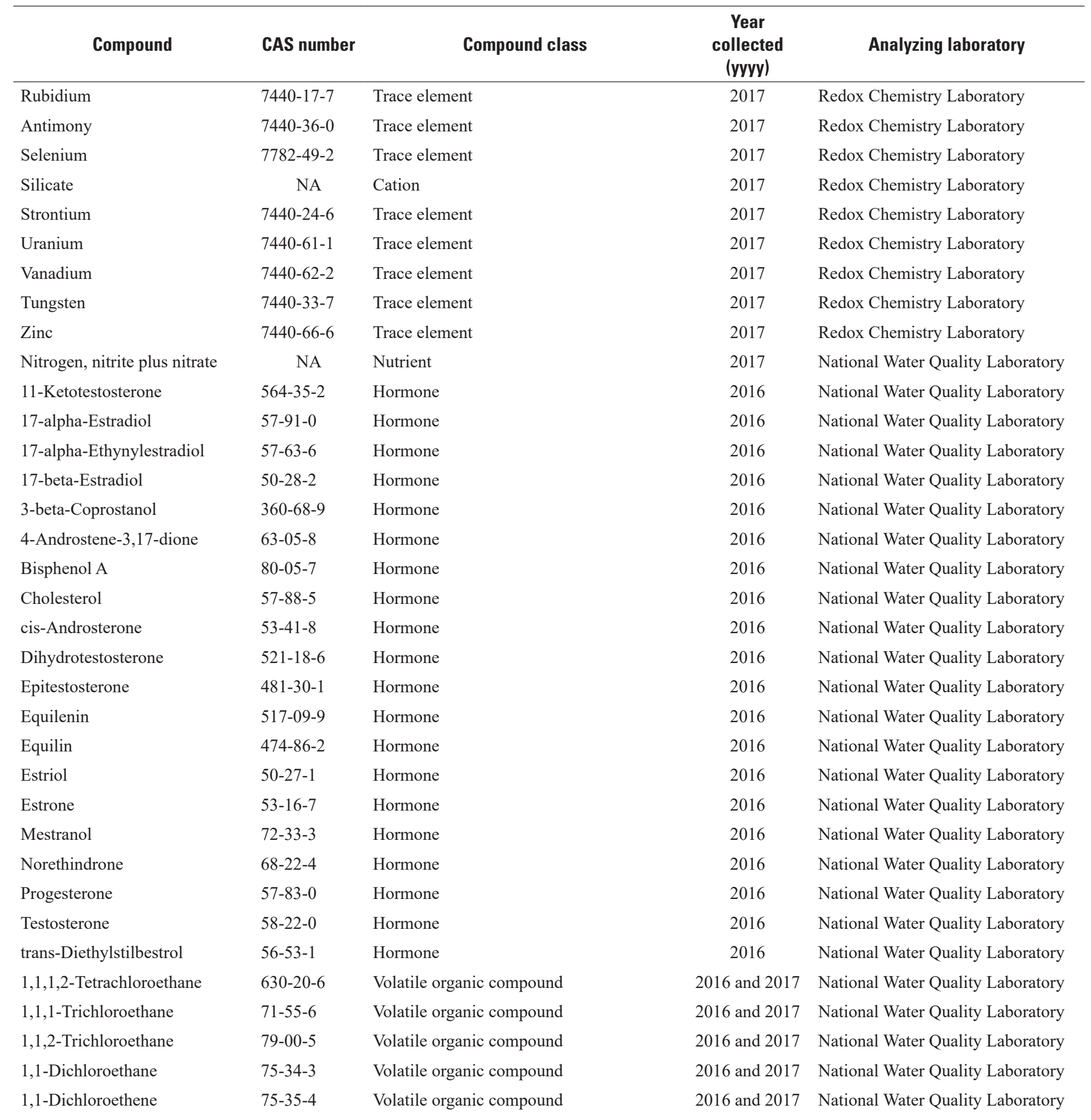


Table 2. Chemical compound information for analyses performed by various laboratories for the U.S. Geological Survey, Environmental Health Mission Area, Infrastructure Project, Tapwater Exposure Pilot Study, 2016-17. —Continued

[NWIS, National Water Information System; CAS, Chemical Abstract Services; y, year; NA, not available; EPA, U.S. Environmental Protection Agency; RED01, enzyme reduction-diazotization; GC, gas chromatograph; LC, liquid chromatography; ICP-MS, inductively coupled plasma- mass spectrometry; cICP-MS, cell inductively coupled plasma-mass spectrometry; HPLC/MS-MS, high performance liquid chromatography-tandem mass spectrometry; HCO3, bicarbonate; $\mu \mathrm{S} / \mathrm{cm}$, microsiemens per centimeter; $\mu \mathrm{g} / \mathrm{L}$, micrograms per liter; mg/L, milligrams per liter; ng/L, nanograms per liter; DAI-LC/MS-MS, direct aqueous injection-liquid chromatography/tandem mass spectrometry; ICP-OES, inductively coupled plasma-optical emission spectrometry; IC, ion chromatography; GCM66, ambient purgeable method (GC/MS); GM016, heat purgeable method (GC/MS); GC/MS-MS, gas chromatography, tandem mass spectrometry; LC/MS-MS, liquid chromatography-tandem mass spectrometry; ELISA, enzyme linked immunosorbent assay for algal toxins; MDL, method detection limit; MRL, minimum reporting level; IRL, interim reporting level; LOQ, limit of quantification; RLDQC, reporting limit by (DQCALC)]

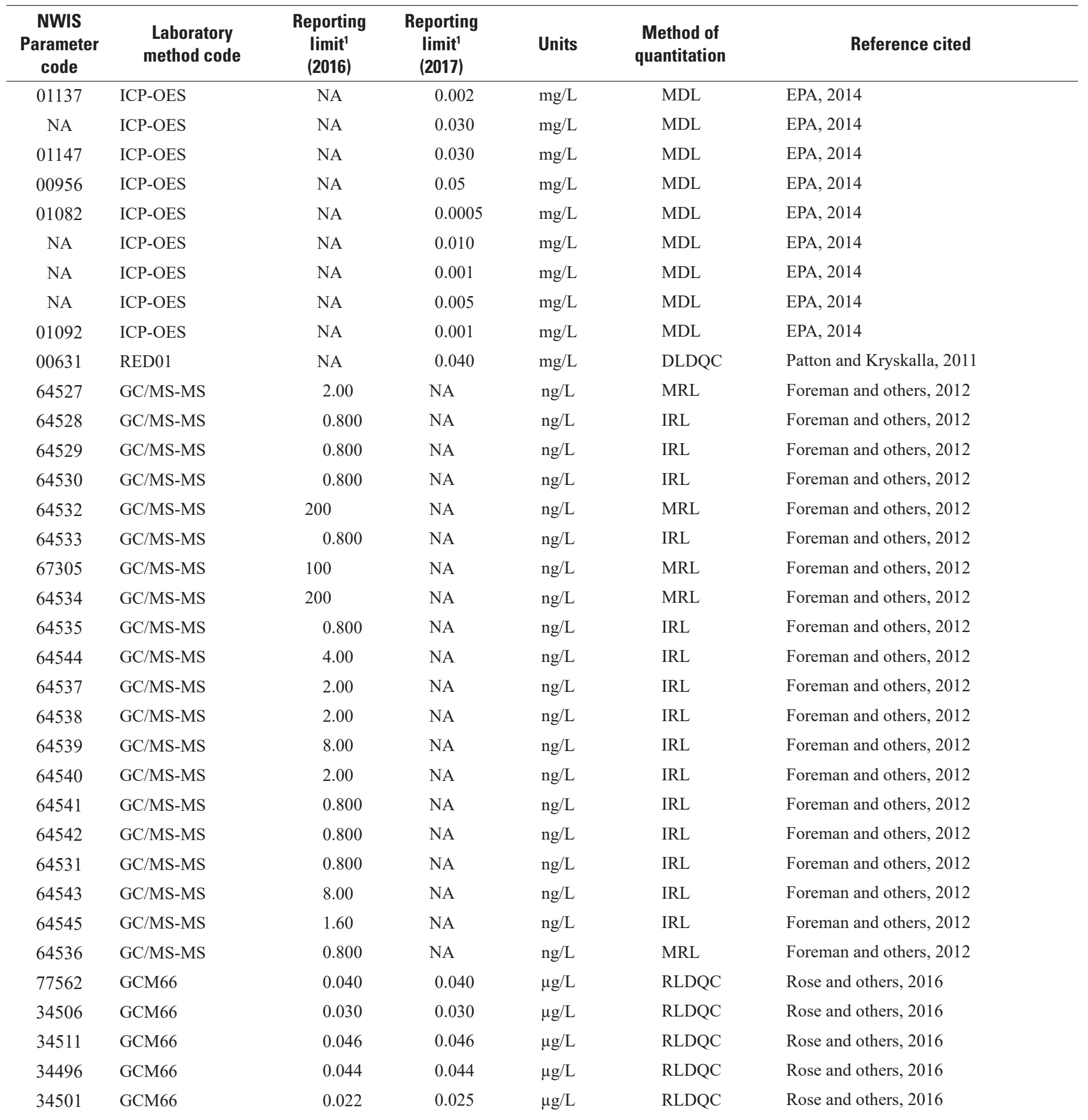


Table 2. Chemical compound information for analyses performed by various laboratories for the U.S. Geological Survey, Environmental Health Mission Area, Infrastructure Project, Tapwater Exposure Pilot Study, 2016-17.-Continued

[NWIS, National Water Information System; CAS, Chemical Abstract Services; y, year; NA, not available; EPA, U.S. Environmental Protection Agency; RED01, enzyme reduction-diazotization; GC, gas chromatograph; LC, liquid chromatography; ICP-MS, inductively coupled plasma-mass spectrometry; cICP-MS, cell inductively coupled plasma-mass spectrometry; HPLC/MS-MS, high performance liquid chromatography/tandem mass spectrometry; HCO3, bicarbonate; $\mu \mathrm{S} / \mathrm{cm}$, microsiemens per centimeter; $\mu \mathrm{g} / \mathrm{L}$, micrograms per liter; $\mathrm{mg} / \mathrm{L}$, milligrams per liter; ng/L, nanograms per liter; DAI-LC/MS-MS, direct aqueous injection-liquid chromatography/tandem mass spectrometry; ICP-OES, inductively coupled plasma-optical emission spectrometry; IC, ion chromatography; GCM66, ambient purgeable method (GC/MS); GM016, heat purgeable method (GC/MS); GC/MS-MS, gas chromatography/tandem mass spectrometry; LC/MS-MS, liquid chromatography-tandem mass spectrometry; ELISA, enzyme linked immunosorbent assay for algal toxins; MDL, method detection limit; MRL, minimum reporting level; IRL, interim reporting level; LOQ, limit of quantification; RLDQC, reporting limit by (DQCALC)]

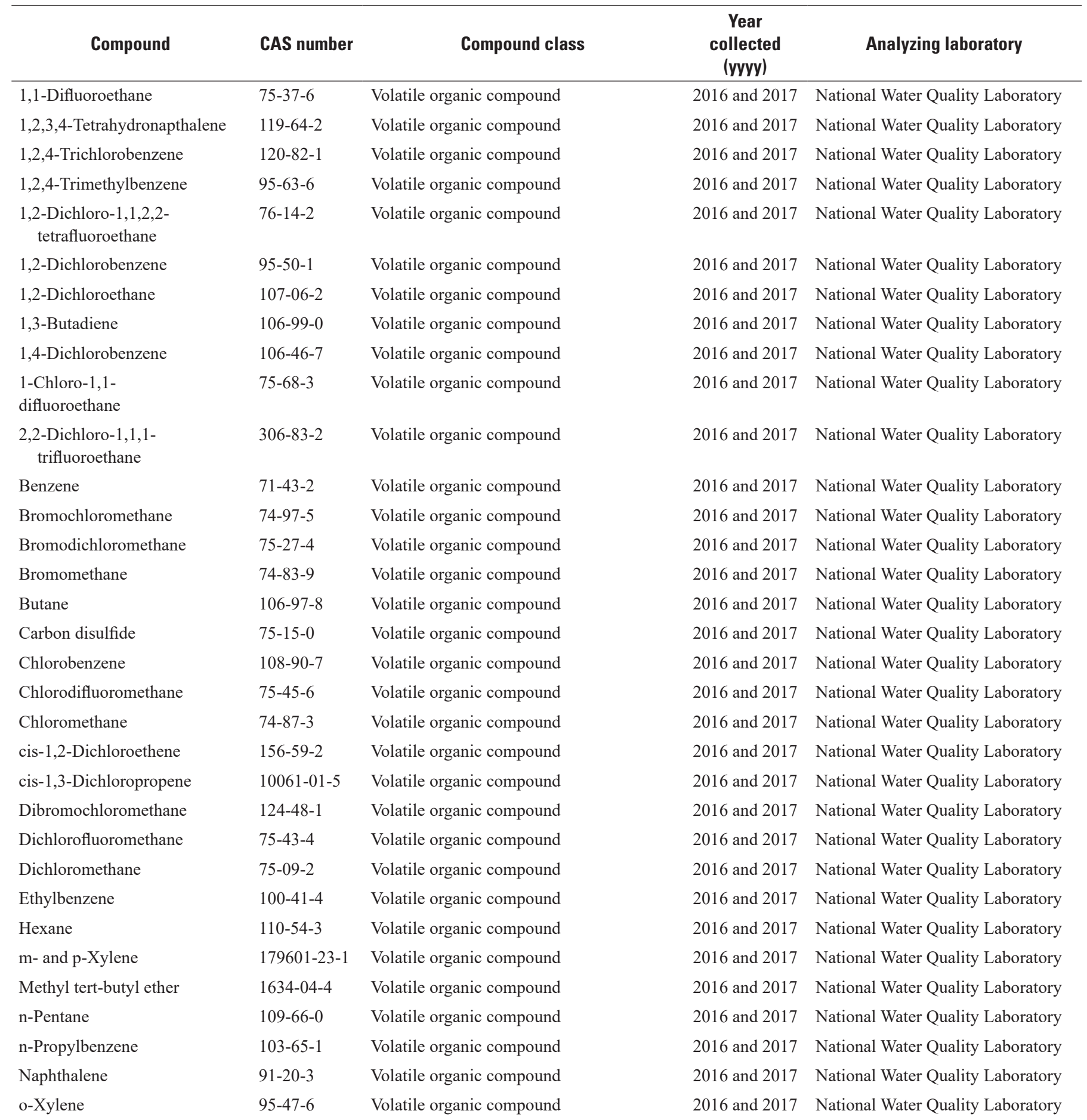


Table 2. $\quad 61$

Table 2. Chemical compound information for analyses performed by various laboratories for the U.S. Geological Survey, Environmental Health Mission Area, Infrastructure Project, Tapwater Exposure Pilot Study, 2016-17. —Continued

[NWIS, National Water Information System; CAS, Chemical Abstract Services; y, year; NA, not available; EPA, U.S. Environmental Protection Agency; RED01, enzyme reduction-diazotization; GC, gas chromatograph; LC, liquid chromatography; ICP-MS, inductively coupled plasma- mass spectrometry; cICP-MS, cell inductively coupled plasma-mass spectrometry; HPLC/MS-MS, high performance liquid chromatography-tandem mass spectrometry; HCO3, bicarbonate; $\mu \mathrm{S} / \mathrm{cm}$, microsiemens per centimeter; $\mu \mathrm{g} / \mathrm{L}$, micrograms per liter; $\mathrm{mg} / \mathrm{L}$, milligrams per liter; ng/L, nanograms per liter; DAI-LC/MS-MS, direct aqueous injection-liquid chromatography/tandem mass spectrometry; ICP-OES, inductively coupled plasma-optical emission spectrometry; IC, ion chromatography; GCM66, ambient purgeable method (GC/MS); GM016, heat purgeable method (GC/MS); GC/MS-MS, gas chromatography, tandem mass spectrometry; LC/MS-MS, liquid chromatography-tandem mass spectrometry; ELISA, enzyme linked immunosorbent assay for algal toxins; MDL, method detection limit; MRL, minimum reporting level; IRL, interim reporting level; LOQ, limit of quantification; RLDQC, reporting limit by (DQCALC)]

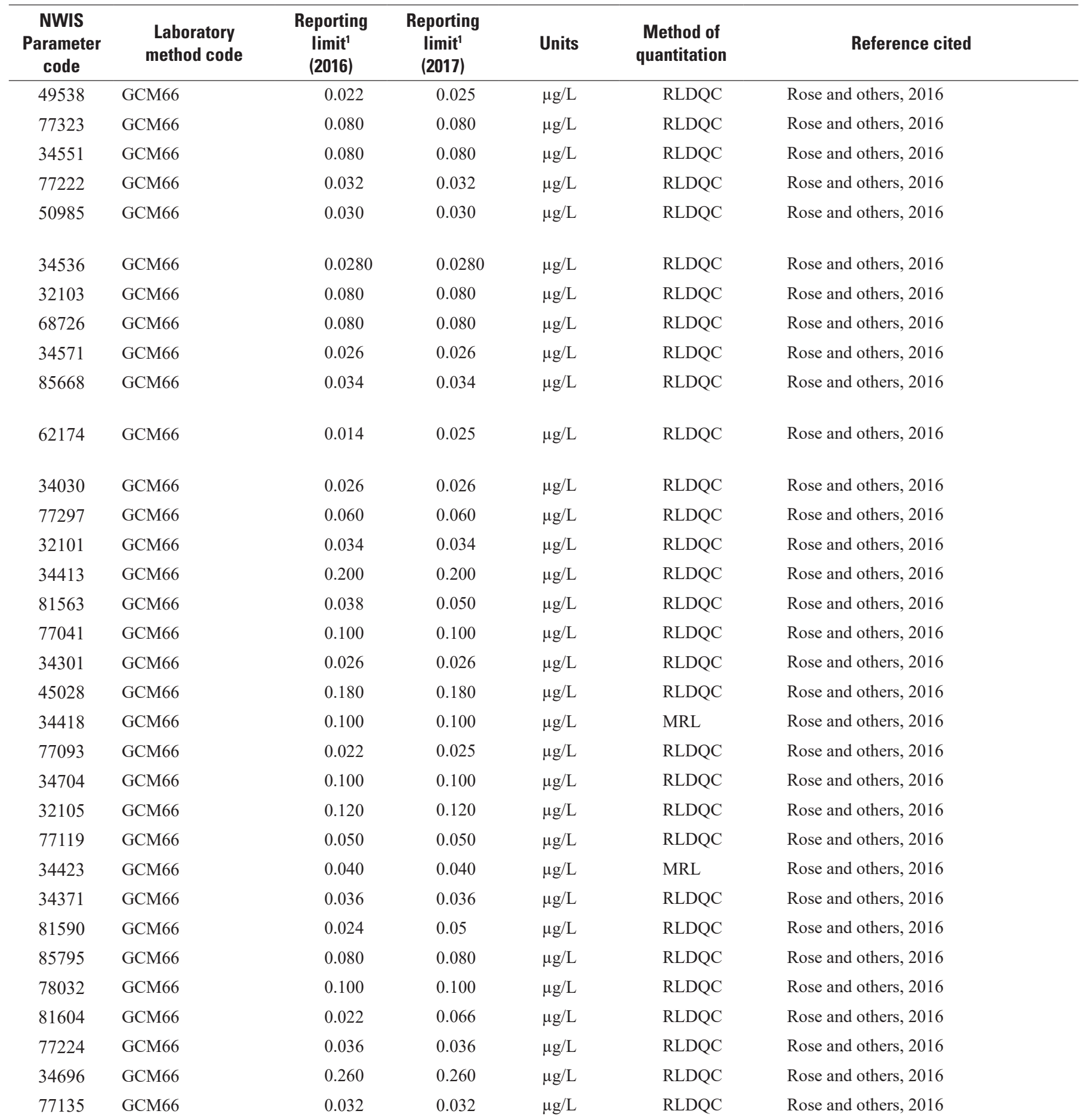


Table 2. Chemical compound information for analyses performed by various laboratories for the U.S. Geological Survey, Environmental Health Mission Area, Infrastructure Project, Tapwater Exposure Pilot Study, 2016-17.-Continued

[NWIS, National Water Information System; CAS, Chemical Abstract Services; y, year; NA, not available; EPA, U.S. Environmental Protection Agency; RED01, enzyme reduction-diazotization; GC, gas chromatograph; LC, liquid chromatography; ICP-MS, inductively coupled plasma-mass spectrometry; cICP-MS, cell inductively coupled plasma-mass spectrometry; HPLC/MS-MS, high performance liquid chromatography/tandem mass spectrometry; HCO3, bicarbonate; $\mu \mathrm{S} / \mathrm{cm}$, microsiemens per centimeter; $\mu \mathrm{g} / \mathrm{L}$, micrograms per liter; $\mathrm{mg} / \mathrm{L}$, milligrams per liter; ng/L, nanograms per liter; DAI-LC/MS-MS, direct aqueous injection-liquid chromatography/tandem mass spectrometry; ICP-OES, inductively coupled plasma-optical emission spectrometry; IC, ion chromatography; GCM66, ambient purgeable method (GC/MS); GM016, heat purgeable method (GC/MS); GC/MS-MS, gas chromatography/tandem mass spectrometry; LC/MS-MS, liquid chromatography-tandem mass spectrometry; ELISA, enzyme linked immunosorbent assay for algal toxins; MDL, method detection limit; MRL, minimum reporting level; IRL, interim reporting level; LOQ, limit of quantification; RLDQC, reporting limit by (DQCALC)]

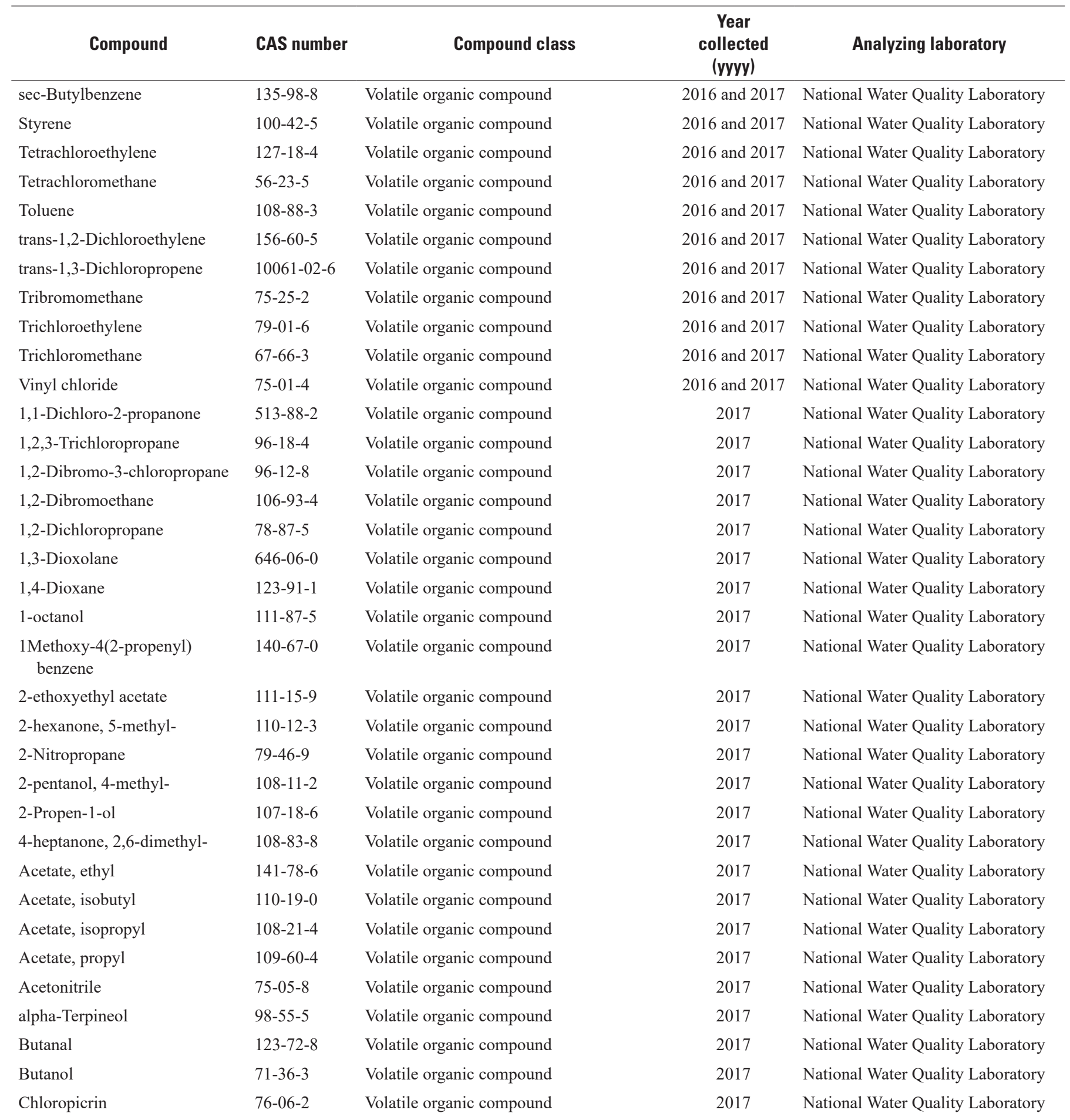


Table 2. $\quad 63$

Table 2. Chemical compound information for analyses performed by various laboratories for the U.S. Geological Survey, Environmental Health Mission Area, Infrastructure Project, Tapwater Exposure Pilot Study, 2016-17. —Continued

[NWIS, National Water Information System; CAS, Chemical Abstract Services; y, year; NA, not available; EPA, U.S. Environmental Protection Agency; RED01, enzyme reduction-diazotization; GC, gas chromatograph; LC, liquid chromatography; ICP-MS, inductively coupled plasma- mass spectrometry; cICP-MS, cell inductively coupled plasma-mass spectrometry; HPLC/MS-MS, high performance liquid chromatography-tandem mass spectrometry; HCO3, bicarbonate; $\mu \mathrm{S} / \mathrm{cm}$, microsiemens per centimeter; $\mu \mathrm{g} / \mathrm{L}$, micrograms per liter; mg/L, milligrams per liter; ng/L, nanograms per liter; DAI-LC/MS-MS, direct aqueous injection-liquid chromatography/tandem mass spectrometry; ICP-OES, inductively coupled plasma-optical emission spectrometry; IC, ion chromatography; GCM66, ambient purgeable method (GC/MS); GM016, heat purgeable method (GC/MS); GC/MS-MS, gas chromatography, tandem mass spectrometry; LC/MS-MS, liquid chromatography-tandem mass spectrometry; ELISA, enzyme linked immunosorbent assay for algal toxins; MDL, method detection limit; MRL, minimum reporting level; IRL, interim reporting level; LOQ, limit of quantification; RLDQC, reporting limit by (DQCALC)]

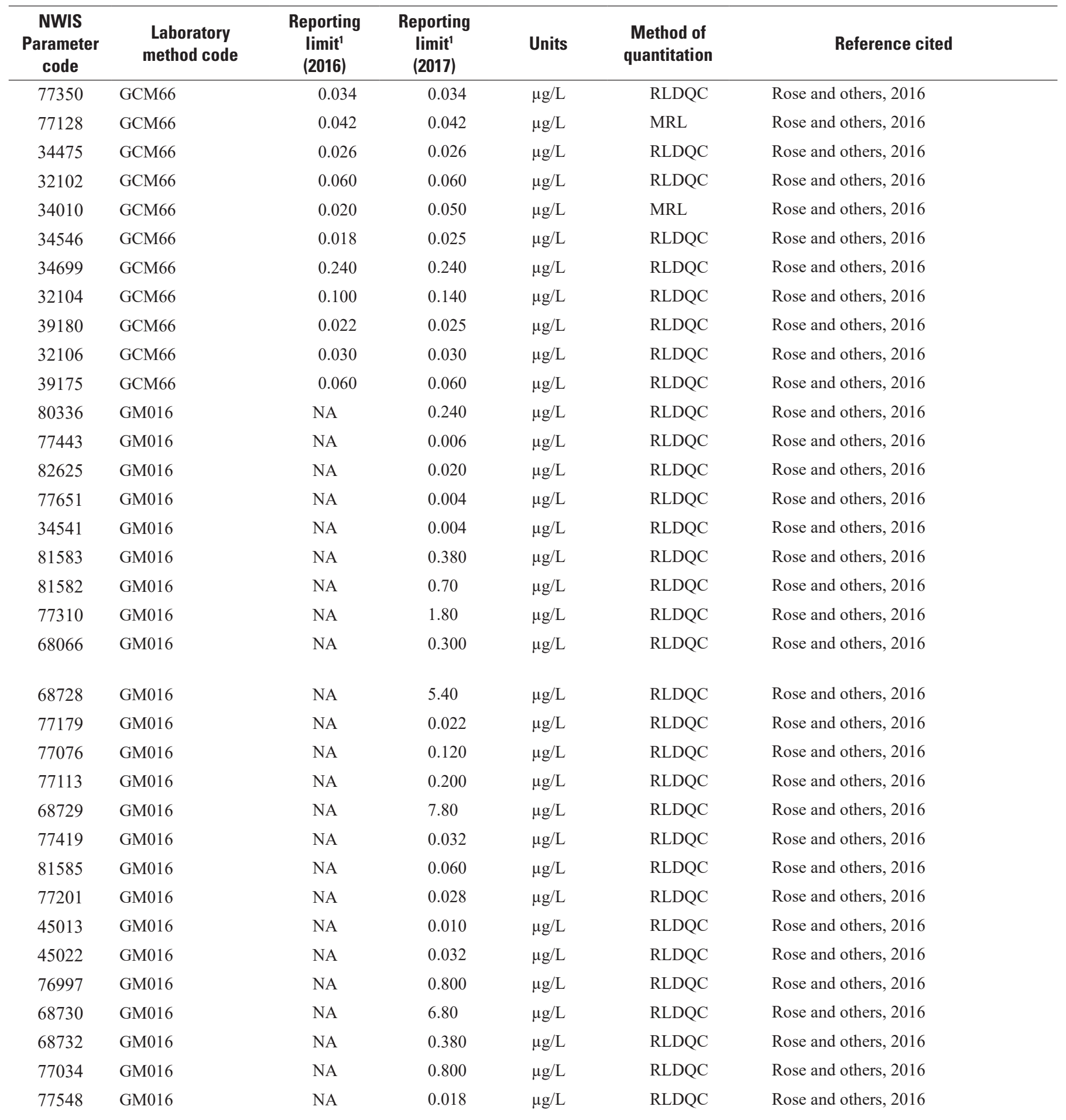


Table 2. Chemical compound information for analyses performed by various laboratories for the U.S. Geological Survey, Environmental Health Mission Area, Infrastructure Project, Tapwater Exposure Pilot Study, 2016-17.-Continued

[NWIS, National Water Information System; CAS, Chemical Abstract Services; y, year; NA, not available; EPA, U.S. Environmental Protection Agency; RED01, enzyme reduction-diazotization; GC, gas chromatograph; LC, liquid chromatography; ICP-MS, inductively coupled plasma-mass spectrometry; cICP-MS, cell inductively coupled plasma-mass spectrometry; HPLC/MS-MS, high performance liquid chromatography/tandem mass spectrometry; HCO3, bicarbonate; $\mu \mathrm{S} / \mathrm{cm}$, microsiemens per centimeter; $\mu \mathrm{g} / \mathrm{L}$, micrograms per liter; $\mathrm{mg} / \mathrm{L}$, milligrams per liter; ng/L, nanograms per liter; DAI-LC/MS-MS, direct aqueous injection-liquid chromatography/tandem mass spectrometry; ICP-OES, inductively coupled plasma-optical emission spectrometry; IC, ion chromatography; GCM66, ambient purgeable method (GC/MS); GM016, heat purgeable method (GC/MS); GC/MS-MS, gas chromatography/tandem mass spectrometry; LC/MS-MS, liquid chromatography-tandem mass spectrometry; ELISA, enzyme linked immunosorbent assay for algal toxins; MDL, method detection limit; MRL, minimum reporting level; IRL, interim reporting level; LOQ, limit of quantification; RLDQC, reporting limit by (DQCALC)]

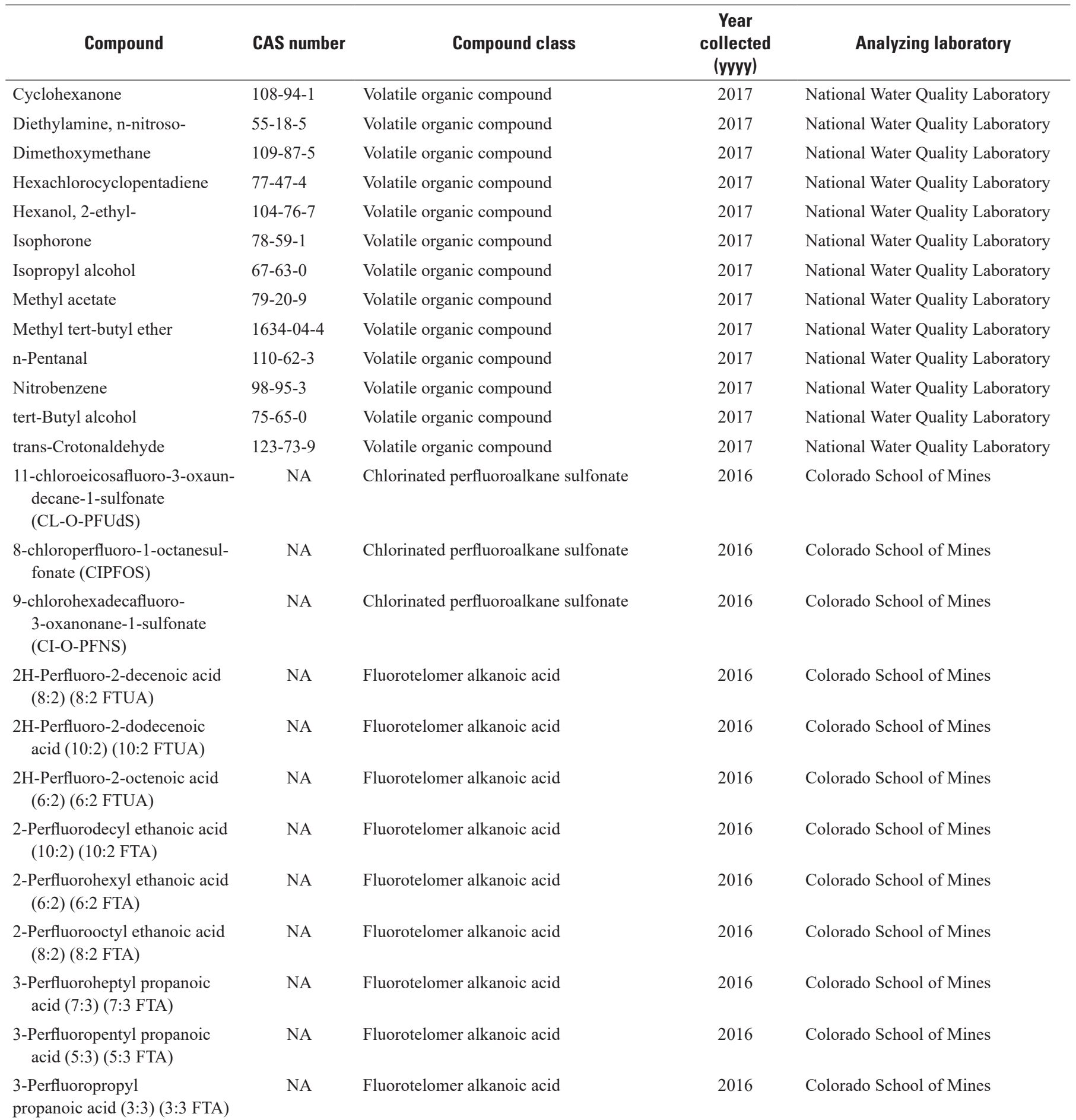


Table 2. Chemical compound information for analyses performed by various laboratories for the U.S. Geological Survey, Environmental Health Mission Area, Infrastructure Project, Tapwater Exposure Pilot Study, 2016-17. —Continued

[NWIS, National Water Information System; CAS, Chemical Abstract Services; y, year; NA, not available; EPA, U.S. Environmental Protection Agency; RED01, enzyme reduction-diazotization; GC, gas chromatograph; LC, liquid chromatography; ICP-MS, inductively coupled plasma- mass spectrometry; cICP-MS, cell inductively coupled plasma-mass spectrometry; HPLC/MS-MS, high performance liquid chromatography-tandem mass spectrometry; HCO3, bicarbonate; $\mu \mathrm{S} / \mathrm{cm}$, microsiemens per centimeter; $\mu \mathrm{g} / \mathrm{L}$, micrograms per liter; mg/L, milligrams per liter; ng/L, nanograms per liter; DAI-LC/MS-MS, direct aqueous injection-liquid chromatography/tandem mass spectrometry; ICP-OES, inductively coupled plasma-optical emission spectrometry; IC, ion chromatography; GCM66, ambient purgeable method (GC/MS); GM016, heat purgeable method (GC/MS); GC/MS-MS, gas chromatography, tandem mass spectrometry; LC/MS-MS, liquid chromatography-tandem mass spectrometry; ELISA, enzyme linked immunosorbent assay for algal toxins; MDL, method detection limit; MRL, minimum reporting level; IRL, interim reporting level; LOQ, limit of quantification; RLDQC, reporting limit by (DQCALC)]

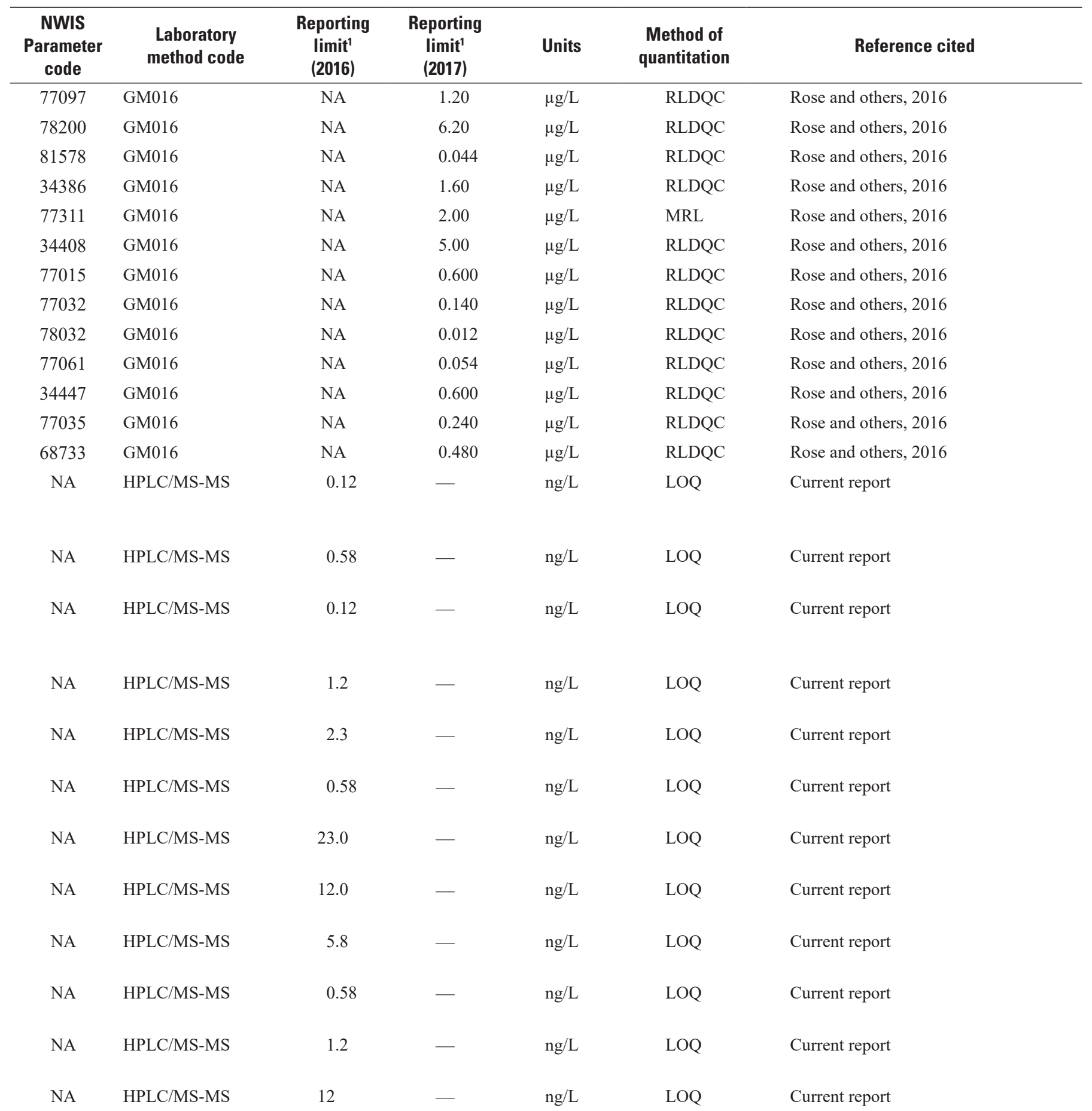


Table 2. Chemical compound information for analyses performed by various laboratories for the U.S. Geological Survey, Environmental Health Mission Area, Infrastructure Project, Tapwater Exposure Pilot Study, 2016-17.-Continued

[NWIS, National Water Information System; CAS, Chemical Abstract Services; y, year; NA, not available; EPA, U.S. Environmental Protection Agency; RED01, enzyme reduction-diazotization; GC, gas chromatograph; LC, liquid chromatography; ICP-MS, inductively coupled plasma-mass spectrometry; cICP-MS, cell inductively coupled plasma-mass spectrometry; HPLC/MS-MS, high performance liquid chromatography/tandem mass spectrometry; HCO3, bicarbonate; $\mu \mathrm{S} / \mathrm{cm}$, microsiemens per centimeter; $\mu \mathrm{g} / \mathrm{L}$, micrograms per liter; $\mathrm{mg} / \mathrm{L}$, milligrams per liter; ng/L, nanograms per liter; DAI-LC/MS-MS, direct aqueous injection-liquid chromatography/tandem mass spectrometry; ICP-OES, inductively coupled plasma-optical emission spectrometry; IC, ion chromatography; GCM66, ambient purgeable method (GC/MS); GM016, heat purgeable method (GC/MS); GC/MS-MS, gas chromatography/tandem mass spectrometry; LC/MS-MS, liquid chromatography-tandem mass spectrometry; ELISA, enzyme linked immunosorbent assay for algal toxins; MDL, method detection limit; MRL, minimum reporting level; IRL, interim reporting level; LOQ, limit of quantification; RLDQC, reporting limit by (DQCALC)]

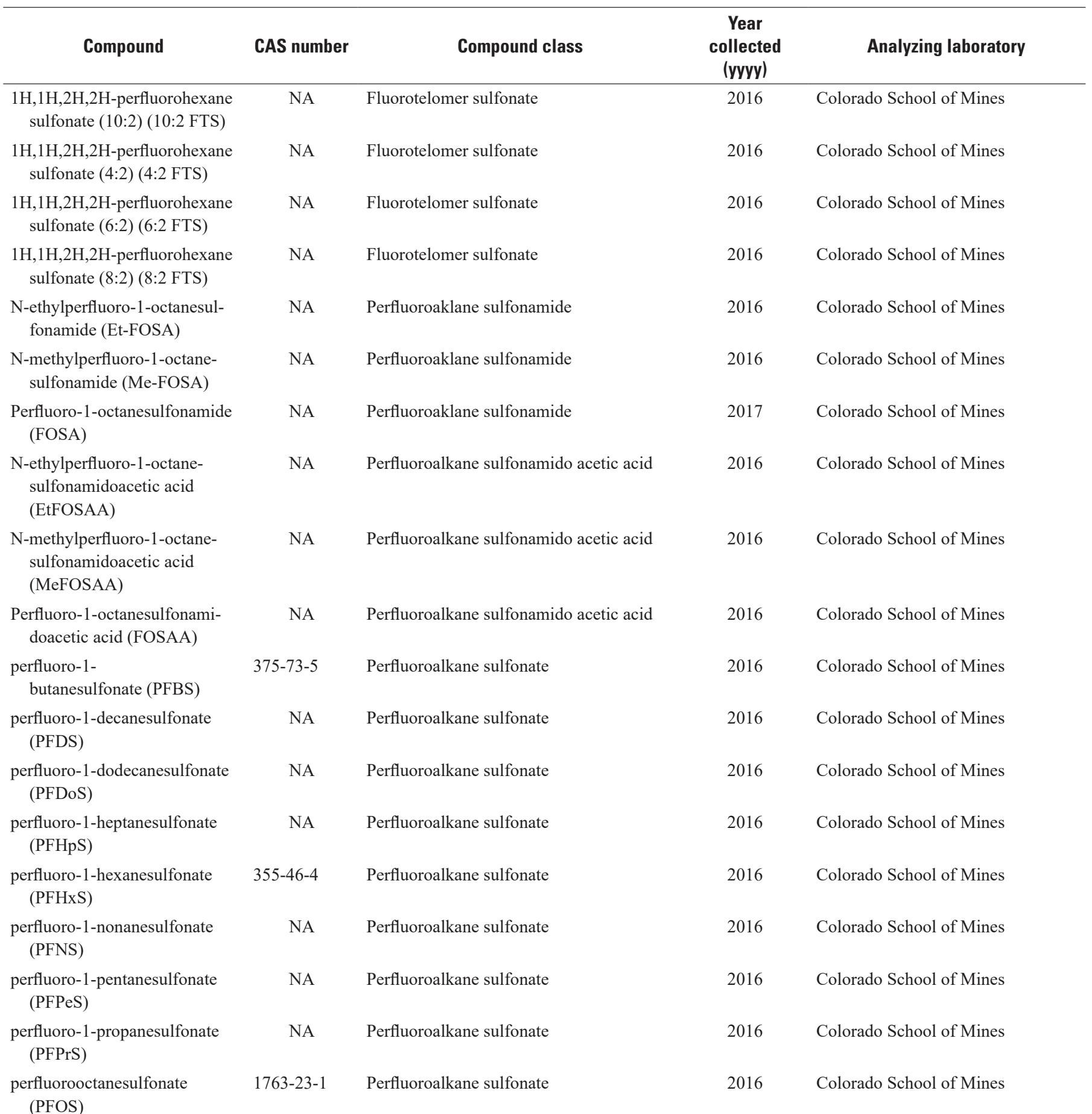


Table 2. Chemical compound information for analyses performed by various laboratories for the U.S. Geological Survey, Environmental Health Mission Area, Infrastructure Project, Tapwater Exposure Pilot Study, 2016-17. —Continued

[NWIS, National Water Information System; CAS, Chemical Abstract Services; y, year; NA, not available; EPA, U.S. Environmental Protection Agency; RED01, enzyme reduction-diazotization; GC, gas chromatograph; LC, liquid chromatography; ICP-MS, inductively coupled plasma- mass spectrometry; cICP-MS, cell inductively coupled plasma-mass spectrometry; HPLC/MS-MS, high performance liquid chromatography-tandem mass spectrometry; HCO3, bicarbonate; $\mu \mathrm{S} / \mathrm{cm}$, microsiemens per centimeter; $\mu \mathrm{g} / \mathrm{L}$, micrograms per liter; $\mathrm{mg} / \mathrm{L}$, milligrams per liter; ng/L, nanograms per liter; DAI-LC/MS-MS, direct aqueous injection-liquid chromatography/tandem mass spectrometry; ICP-OES, inductively coupled plasma-optical emission spectrometry; IC, ion chromatography; GCM66, ambient purgeable method (GC/MS); GM016, heat purgeable method (GC/MS); GC/MS-MS, gas chromatography, tandem mass spectrometry; LC/MS-MS, liquid chromatography-tandem mass spectrometry; ELISA, enzyme linked immunosorbent assay for algal toxins; MDL, method detection limit; MRL, minimum reporting level; IRL, interim reporting level; LOQ, limit of quantification; RLDQC, reporting limit by (DQCALC)]

\begin{tabular}{|c|c|c|c|c|c|c|}
\hline $\begin{array}{c}\text { NWIS } \\
\text { Parameter } \\
\text { code }\end{array}$ & $\begin{array}{l}\text { Laboratory } \\
\text { method code }\end{array}$ & $\begin{array}{c}\text { Reporting } \\
\text { limit' }^{1} \\
(2016)\end{array}$ & $\begin{array}{c}\text { Reporting } \\
\text { limit }^{1} \\
(2017)\end{array}$ & Units & $\begin{array}{c}\text { Method of } \\
\text { quantitation }\end{array}$ & Reference cited \\
\hline NA & HPLC/MS-MS & 0.12 & - & $\mathrm{ng} / \mathrm{L}$ & LOQ & Current report \\
\hline NA & HPLC/MS-MS & 1.2 & - & $\mathrm{ng} / \mathrm{L}$ & LOQ & Current report \\
\hline NA & HPLC/MS-MS & 1.2 & - & $\mathrm{ng} / \mathrm{L}$ & LOQ & Current report \\
\hline NA & HPLC/MS-MS & 5.80 & - & $\mathrm{ng} / \mathrm{L}$ & LOQ & Current report \\
\hline NA & HPLC/MS-MS & 0.58 & - & $\mathrm{ng} / \mathrm{L}$ & LOQ & Current report \\
\hline NA & HPLC/MS-MS & 1.2 & - & $\mathrm{ng} / \mathrm{L}$ & LOQ & Current report \\
\hline NA & HPLC/MS-MS & 0.12 & - & $\mathrm{ng} / \mathrm{L}$ & LOQ & Current report \\
\hline NA & HPLC/MS-MS & 2.3 & - & $\mathrm{ng} / \mathrm{L}$ & LOQ & Current report \\
\hline NA & HPLC/MS-MS & 1.2 & - & $\mathrm{ng} / \mathrm{L}$ & LOQ & Current report \\
\hline NA & HPLC/MS-MS & 23 & - & $\mathrm{ng} / \mathrm{L}$ & LOQ & Current report \\
\hline NA & HPLC/MS-MS & 0.58 & - & $\mathrm{ng} / \mathrm{L}$ & LOQ & Current report \\
\hline NA & HPLC/MS-MS & 0.58 & - & $\mathrm{ng} / \mathrm{L}$ & LOQ & Current report \\
\hline
\end{tabular}


Table 2. Chemical compound information for analyses performed by various laboratories for the U.S. Geological Survey, Environmental Health Mission Area, Infrastructure Project, Tapwater Exposure Pilot Study, 2016-17._Continued

[NWIS, National Water Information System; CAS, Chemical Abstract Services; y, year; NA, not available; EPA, U.S. Environmental Protection Agency; RED01, enzyme reduction-diazotization; GC, gas chromatograph; LC, liquid chromatography; ICP-MS, inductively coupled plasma-mass spectrometry; cICP-MS, cell inductively coupled plasma-mass spectrometry; HPLC/MS-MS, high performance liquid chromatography/tandem mass spectrometry; HCO3, bicarbonate; $\mu \mathrm{S} / \mathrm{cm}$, microsiemens per centimeter; $\mu \mathrm{g} / \mathrm{L}$, micrograms per liter; $\mathrm{mg} / \mathrm{L}$, milligrams per liter; ng/L, nanograms per liter; DAI-LC/MS-MS, direct aqueous injection-liquid chromatography/tandem mass spectrometry; ICP-OES, inductively coupled plasma-optical emission spectrometry; IC, ion chromatography; GCM66, ambient purgeable method (GC/MS); GM016, heat purgeable method (GC/MS); GC/MS-MS, gas chromatography/tandem mass spectrometry; LC/MS-MS, liquid chromatography-tandem mass spectrometry; ELISA, enzyme linked immunosorbent assay for algal toxins; MDL, method detection limit; MRL, minimum reporting level; IRL, interim reporting level; LOQ, limit of quantification; RLDQC, reporting limit by (DQCALC)]

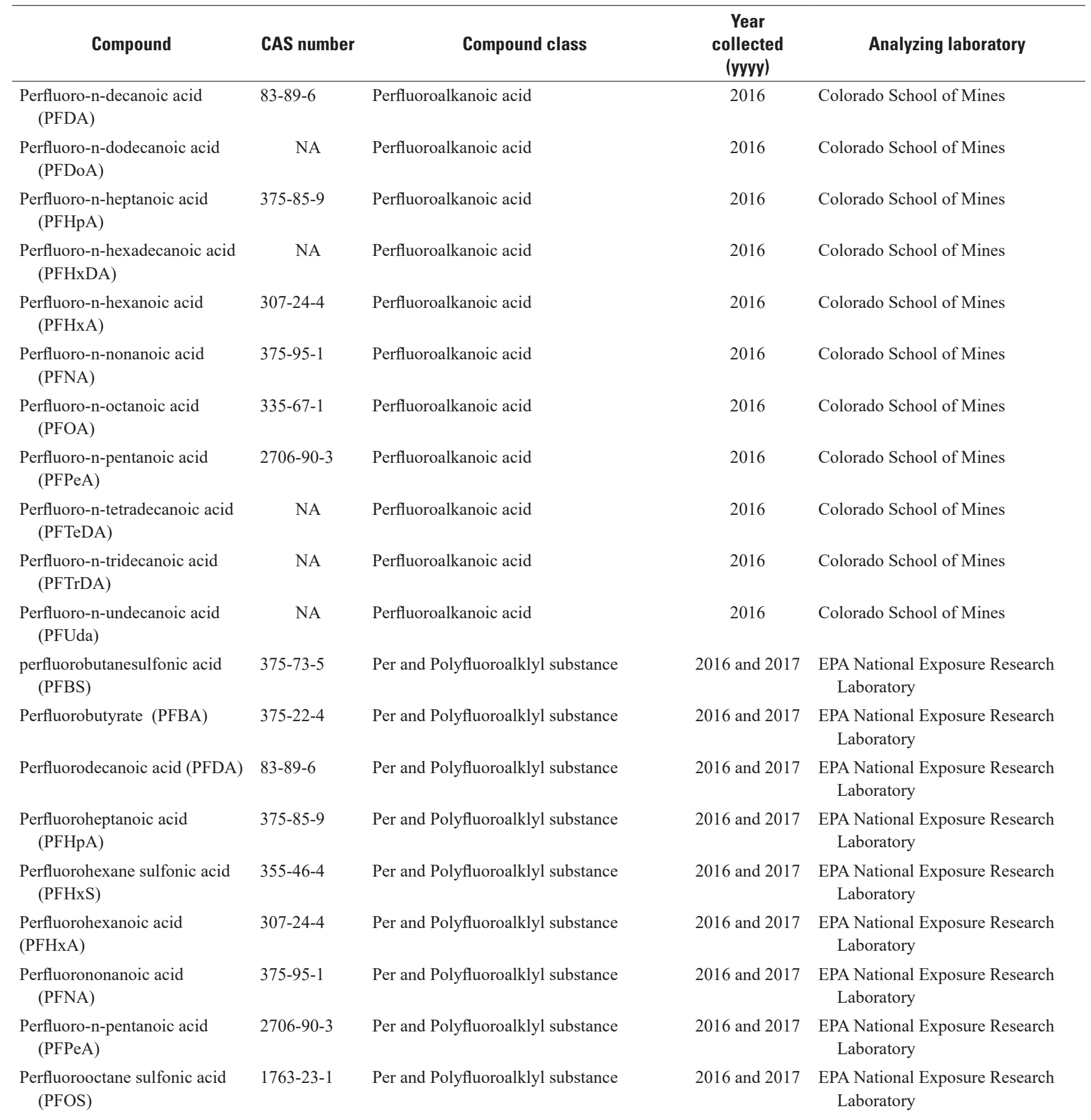


Table 2. Chemical compound information for analyses performed by various laboratories for the U.S. Geological Survey, Environmental Health Mission Area, Infrastructure Project, Tapwater Exposure Pilot Study, 2016-17. —Continued

[NWIS, National Water Information System; CAS, Chemical Abstract Services; y, year; NA, not available; EPA, U.S. Environmental Protection Agency; RED01, enzyme reduction-diazotization; GC, gas chromatograph; LC, liquid chromatography; ICP-MS, inductively coupled plasma- mass spectrometry; cICP-MS, cell inductively coupled plasma-mass spectrometry; HPLC/MS-MS, high performance liquid chromatography-tandem mass spectrometry; HCO3, bicarbonate; $\mu \mathrm{S} / \mathrm{cm}$, microsiemens per centimeter; $\mu \mathrm{g} / \mathrm{L}$, micrograms per liter; $\mathrm{mg} / \mathrm{L}$, milligrams per liter; ng/L, nanograms per liter; DAI-LC/MS-MS, direct aqueous injection-liquid chromatography/tandem mass spectrometry; ICP-OES, inductively coupled plasma-optical emission spectrometry; IC, ion chromatography; GCM66, ambient purgeable method (GC/MS); GM016, heat purgeable method (GC/MS); GC/MS-MS, gas chromatography, tandem mass spectrometry; LC/MS-MS, liquid chromatography-tandem mass spectrometry; ELISA, enzyme linked immunosorbent assay for algal toxins; MDL, method detection limit; MRL, minimum reporting level; IRL, interim reporting level; LOQ, limit of quantification; RLDQC, reporting limit by (DQCALC)]

\begin{tabular}{|c|c|c|c|c|c|c|}
\hline $\begin{array}{c}\text { NWIS } \\
\text { Parameter } \\
\text { code }\end{array}$ & $\begin{array}{l}\text { Laboratory } \\
\text { method code }\end{array}$ & $\begin{array}{c}\text { Reporting } \\
\text { limit }^{1} \\
(2016)\end{array}$ & $\begin{array}{c}\text { Reporting } \\
\text { limit }^{1} \\
(2017)\end{array}$ & Units & $\begin{array}{c}\text { Method of } \\
\text { quantitation }\end{array}$ & Reference cited \\
\hline NA & HPLC/MS-MS & 0.58 & - & $\mathrm{ng} / \mathrm{L}$ & LOQ & Current report \\
\hline NA & HPLC/MS-MS & 0.58 & - & $\mathrm{ng} / \mathrm{L}$ & LOQ & Current report \\
\hline NA & HPLC/MS-MS & 5.8 & - & $\mathrm{ng} / \mathrm{L}$ & LOQ & Current report \\
\hline NA & HPLC/MS-MS & 2.3 & 一 & $\mathrm{ng} / \mathrm{L}$ & LOQ & Current report \\
\hline NA & HPLC/MS-MS & 2.3 & - & $\mathrm{ng} / \mathrm{L}$ & LOQ & Current report \\
\hline NA & HPLC/MS-MS & 12 & - & $\mathrm{ng} / \mathrm{L}$ & LOQ & Current report \\
\hline NA & HPLC/MS-MS & 2.3 & - & $\mathrm{ng} / \mathrm{L}$ & LOQ & Current report \\
\hline NA & HPLC/MS-MS & 0.58 & 一 & $\mathrm{ng} / \mathrm{L}$ & LOQ & Current report \\
\hline NA & HPLC/MS-MS & 0.58 & - & $\mathrm{ng} / \mathrm{L}$ & LOQ & Current report \\
\hline NA & HPLC/MS-MS & 5.00 & 5.00 & $\mathrm{ng} / \mathrm{L}$ & LOQ & EPA, 2017 \\
\hline NA & HPLC/MS-MS & 5.00 & 5.00 & $\mathrm{ng} / \mathrm{L}$ & LOQ & EPA, 2017 \\
\hline NA & HPLC/MS-MS & 5.00 & 5.00 & $\mathrm{ng} / \mathrm{L}$ & LOQ & EPA, 2017 \\
\hline NA & HPLC/MS-MS & 5.00 & 5.00 & $\mathrm{ng} / \mathrm{L}$ & LOQ & EPA, 2017 \\
\hline NA & HPLC/MS-MS & 5.00 & 5.00 & $\mathrm{ng} / \mathrm{L}$ & LOQ & EPA, 2017 \\
\hline
\end{tabular}


Table 2. Chemical compound information for analyses performed by various laboratories for the U.S. Geological Survey, Environmental Health Mission Area, Infrastructure Project, Tapwater Exposure Pilot Study, 2016-17.-Continued

[NWIS, National Water Information System; CAS, Chemical Abstract Services; y, year; NA, not available; EPA, U.S. Environmental Protection Agency; RED01, enzyme reduction-diazotization; GC, gas chromatograph; LC, liquid chromatography; ICP-MS, inductively coupled plasma-mass spectrometry; cICP-MS, cell inductively coupled plasma-mass spectrometry; HPLC/MS-MS, high performance liquid chromatography/tandem mass spectrometry; HCO3, bicarbonate; $\mu \mathrm{S} / \mathrm{cm}$, microsiemens per centimeter; $\mu \mathrm{g} / \mathrm{L}$, micrograms per liter; $\mathrm{mg} / \mathrm{L}$, milligrams per liter; ng/L, nanograms per liter; DAI-LC/MS-MS, direct aqueous injection-liquid chromatography/tandem mass spectrometry; ICP-OES, inductively coupled plasma-optical emission spectrometry; IC, ion chromatography; GCM66, ambient purgeable method (GC/MS); GM016, heat purgeable method (GC/MS); GC/MS-MS, gas chromatography/tandem mass spectrometry; LC/MS-MS, liquid chromatography-tandem mass spectrometry; ELISA, enzyme linked immunosorbent assay for algal toxins; MDL, method detection limit; MRL, minimum reporting level; IRL, interim reporting level; LOQ, limit of quantification; RLDQC, reporting limit by (DQCALC)]

\begin{tabular}{|c|c|c|c|c|}
\hline Compound & CAS number & Compound class & $\begin{array}{c}\text { Year } \\
\text { collected } \\
\text { (yyyy) }\end{array}$ & Analyzing laboratory \\
\hline Perfluorooctanoic acid (PFOA) & $335-67-1$ & Per and Polyfluoroalklyl substance & 2016 and 2017 & $\begin{array}{l}\text { EPA National Exposure Research } \\
\text { Laboratory }\end{array}$ \\
\hline Perfluorobutyrate (PFBA) & $375-22-4$ & Per and Polyfluoroalklyl substance & 2016 and 2017 & National Water Quality Laboratory \\
\hline Perfluorodecanoic acid (PFDA) & $83-89-6$ & Per and Polyfluoroalklyl substance & 2022 and 2017 & National Water Quality Laboratory \\
\hline $\begin{array}{l}\text { Perfluorohexanoic acid } \\
\text { (PFHxA) }\end{array}$ & $307-24-4$ & Per and Polyfluoroalklyl substance & 2018 and 2017 & National Water Quality Laboratory \\
\hline $\begin{array}{l}\text { Perfluorononanoic acid } \\
\text { (PFNA) }\end{array}$ & $375-95-1$ & Per and Polyfluoroalklyl substance & 2021 and 2017 & National Water Quality Laboratory \\
\hline $\begin{array}{l}\text { perfluoro-1-decanesulfonate } \\
\text { (PFDS) }\end{array}$ & NA & Perfluoroalkane sulfonate & 2031 and 2017 & National Water Quality Laboratory \\
\hline $\begin{array}{l}\text { perfluoro-1-heptanesulfonate } \\
\qquad \text { (PFHpS) }\end{array}$ & NA & Perfluoroalkane sulfonate & 2029 and 2017 & National Water Quality Laboratory \\
\hline $\begin{array}{l}\text { perfluoro-1-hexanesulfonate } \\
\text { (PFHxS) }\end{array}$ & $355-46-4$ & Perfluoroalkane sulfonate & 2028 and 2017 & National Water Quality Laboratory \\
\hline $\begin{array}{l}\text { perfluorooctanesulfonate } \\
\text { (PFOS) }\end{array}$ & $1763-23-1$ & Perfluoroalkane sulfonate & 2030 and 2017 & National Water Quality Laboratory \\
\hline $\begin{array}{l}\text { Perfluoro-n-dodecanoic acid } \\
\qquad \text { (PFDoA) }\end{array}$ & $307-55-14$ & Perfluoroalkanoic acid & 2024 and 2017 & National Water Quality Laboratory \\
\hline
\end{tabular}

${ }^{1}$ Reporting limit and method detection limits can be found in references cited. 
Table 2. $\quad 71$

Table 2. Chemical compound information for analyses performed by various laboratories for the U.S. Geological Survey, Environmental Health Mission Area, Infrastructure Project, Tapwater Exposure Pilot Study, 2016-17. —Continued

[NWIS, National Water Information System; CAS, Chemical Abstract Services; y, year; NA, not available; EPA, U.S. Environmental Protection Agency; RED01, enzyme reduction-diazotization; GC, gas chromatograph; LC, liquid chromatography; ICP-MS, inductively coupled plasma- mass spectrometry; cICP-MS, cell inductively coupled plasma-mass spectrometry; HPLC/MS-MS, high performance liquid chromatography-tandem mass spectrometry; HCO3, bicarbonate; $\mu \mathrm{S} / \mathrm{cm}$, microsiemens per centimeter; $\mu \mathrm{g} / \mathrm{L}$, micrograms per liter; $\mathrm{mg} / \mathrm{L}$, milligrams per liter; ng/L, nanograms per liter; DAI-LC/MS-MS, direct aqueous injection-liquid chromatography/tandem mass spectrometry; ICP-OES, inductively coupled plasma-optical emission spectrometry; IC, ion chromatography; GCM66, ambient purgeable method (GC/MS); GM016, heat purgeable method (GC/MS); GC/MS-MS, gas chromatography, tandem mass spectrometry; LC/MS-MS, liquid chromatography-tandem mass spectrometry; ELISA, enzyme linked immunosorbent assay for algal toxins; MDL, method detection limit; MRL, minimum reporting level; IRL, interim reporting level; LOQ, limit of quantification; RLDQC, reporting limit by (DQCALC)]

\begin{tabular}{|c|c|c|c|c|c|c|}
\hline $\begin{array}{l}\text { NWIS } \\
\text { Parameter } \\
\text { code }\end{array}$ & $\begin{array}{l}\text { Laboratory } \\
\text { method code }\end{array}$ & $\begin{array}{l}\text { Reporting } \\
\text { limit }^{1} \\
(2016)\end{array}$ & $\begin{array}{l}\text { Reporting } \\
\text { limit }^{1} \\
(2017)\end{array}$ & Units & $\begin{array}{l}\text { Method of } \\
\text { quantitation }\end{array}$ & Reference cited \\
\hline $\mathrm{NA}$ & HPLC/MS-MS & 5.00 & 5.00 & $\mathrm{ng} / \mathrm{L}$ & LOQ & EPA, 2017 \\
\hline NA & DAI-LC/MS-MS & 50.0 & 5.00 & $\mathrm{ng} / \mathrm{L}$ & LOQ & NA \\
\hline NA & DAI-LC/MS-MS & 134 & 5.00 & $\mathrm{ng} / \mathrm{L}$ & LOQ & NA \\
\hline $\mathrm{NA}$ & DAI-LC/MS-MS & 5.00 & 5.00 & $\mathrm{ng} / \mathrm{L}$ & LOQ & NA \\
\hline NA & DAI-LC/MS-MS & 5.00 & 5.00 & $\mathrm{ng} / \mathrm{L}$ & LOQ & NA \\
\hline NA & DAI-LC/MS-MS & 35.0 & 5.00 & $\mathrm{ng} / \mathrm{L}$ & LOQ & NA \\
\hline NA & DAI-LC/MS-MS & 10.0 & 5.00 & $\mathrm{ng} / \mathrm{L}$ & LOQ & NA \\
\hline NA & DAI-LC/MS-MS & 74.0 & 5.00 & $\mathrm{ng} / \mathrm{L}$ & LOQ & NA \\
\hline NA & DAI-LC/MS-MS & 50.0 & 5.00 & $\mathrm{ng} / \mathrm{L}$ & LOQ & NA \\
\hline NA & DAI-LC/MS-MS & 16.0 & 5.00 & $\mathrm{ng} / \mathrm{L}$ & LOQ & NA \\
\hline NA & DAI-LC/MS-MS & 5.00 & 5.00 & $\mathrm{ng} / \mathrm{L}$ & LOQ & NA \\
\hline NA & DAI-LC/MS-MS & 50.0 & 5.00 & $\mathrm{ng} / \mathrm{L}$ & LOQ & NA \\
\hline $\mathrm{NA}$ & DAI-LC/MS-MS & 500 & 5.00 & $\mathrm{ng} / \mathrm{L}$ & LOQ & NA \\
\hline NA & DAI-LC/MS-MS & 50.0 & 5.00 & $\mathrm{ng} / \mathrm{L}$ & LOQ & NA \\
\hline NA & DAI-LC/MS-MS & 250 & 5.00 & $\mathrm{ng} / \mathrm{L}$ & LOQ & NA \\
\hline NA & DAI-LC/MS-MS & 500 & 5.00 & $\mathrm{ng} / \mathrm{L}$ & LOQ & NA \\
\hline NA & DAI-LC/MS-MS & 50.0 & 5.00 & $\mathrm{ng} / \mathrm{L}$ & LOQ & NA \\
\hline
\end{tabular}



Apendixes 1-3 
Appendix 1. Target analytes and internal standards used for quantitation of per- and polyfluorinated alkyl substances analyzed at the Colorado School of Mines, Golden, Colorado.

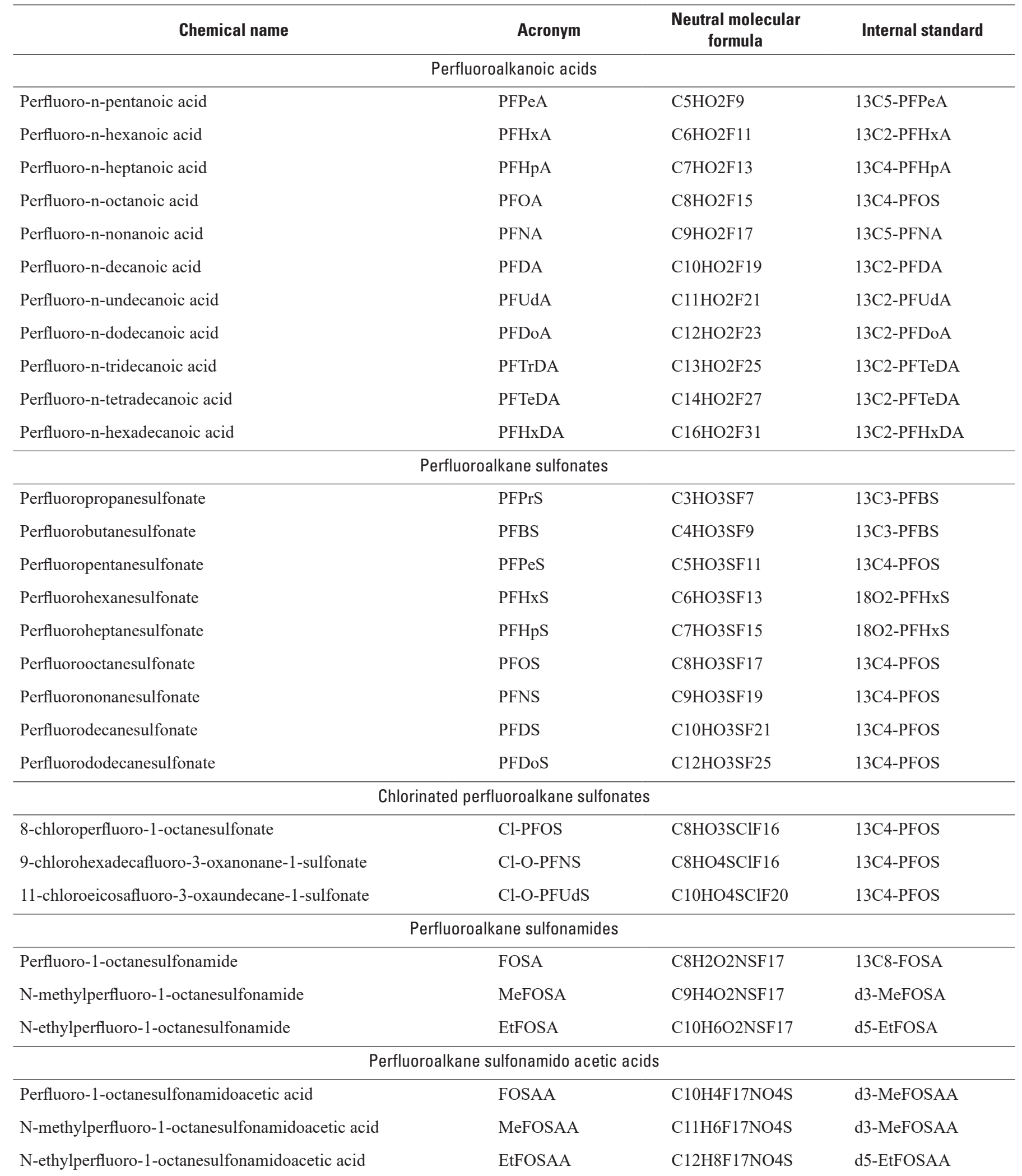


Appendix 1. Target analytes and internal standards used for quantitation of per- and polyfluorinated alkyl substances analyzed at the Colorado School of Mines, Golden, Colorado.-Continued

\begin{tabular}{|c|c|c|c|}
\hline Chemical name & Acronym & $\begin{array}{l}\text { Neutral molecular } \\
\text { formula }\end{array}$ & Internal standard \\
\hline \multicolumn{4}{|c|}{ Fluorotelomer sulfonates } \\
\hline 4:2 fluorotelomer sulfonate & 4:2 FTS & C6H5O3SF9 & $13 \mathrm{C} 2-4: 2 \mathrm{FTS}$ \\
\hline 6:2 fluorotelomer sulfonate & $6: 2$ FTS & $\mathrm{C} 8 \mathrm{H} 5 \mathrm{O} 3 \mathrm{SF} 13$ & 13C4-PFOA \\
\hline $8: 2$ fluorotelomer sulfonate & $8: 2$ FTS & $\mathrm{C} 10 \mathrm{H} 5 \mathrm{O} 3 \mathrm{SF} 17$ & $13 \mathrm{C} 2-8: 2 \mathrm{FTS}$ \\
\hline 10:2 fluorotelomer sulfonate & 10:2 FTS & $\mathrm{C} 12 \mathrm{H} 5 \mathrm{O} 3 \mathrm{SF} 21$ & 13C2-8:2 FTS \\
\hline \multicolumn{4}{|c|}{ Fluorotelomer alkanoic acids } \\
\hline 3-Perfluoropropyl propanoic acid (3:3) & 3:3 FTA & C6H5F7O2 & 13C2-6:2 FTA \\
\hline 3-Perfluoropentyl propanoic acid (5:3) & 5:3 FTA & C8H5F11O2 & $13 \mathrm{C} 2-8: 2 \mathrm{FTA}$ \\
\hline 3-Perfluoroheptyl propanoic acid (7:3) & 7:3 FTA & $\mathrm{C} 10 \mathrm{H} 5 \mathrm{~F} 15 \mathrm{O} 2$ & 13C2-10:2 FTA \\
\hline 2-Perfluorohexyl ethanoic acid (6:2) & 6:2 FTA & $\mathrm{C} 8 \mathrm{H} 3 \mathrm{~F} 13 \mathrm{O} 2$ & $13 \mathrm{C} 2-6: 2 \mathrm{FTA}$ \\
\hline 2-Perfluorooctyl ethanoic acid (8:2) & $8: 2$ FTA & $\mathrm{C} 10 \mathrm{H} 3 \mathrm{~F} 17 \mathrm{O} 2$ & 13C2-8:2 FTA \\
\hline 2-Perfluorodecyl ethanoic acid (10:2) & 10:2 FTA & $\mathrm{C} 12 \mathrm{H} 3 \mathrm{~F} 21 \mathrm{O} 2$ & 13C2-10:2 FTA \\
\hline 2H-Perfluoro-2-octenoic acid (6:2) & 6:2 FTUA & $\mathrm{C} 8 \mathrm{H} 2 \mathrm{~F} 12 \mathrm{O} 2$ & 13C2-6:2FTUA \\
\hline 2H-Perfluoro-2-decenoic acid (8:2) & 8:2 FTUA & $\mathrm{C} 10 \mathrm{H} 2 \mathrm{~F} 16 \mathrm{O} 2$ & 13C2-8:2 FTUA \\
\hline 2H-Perfluoro-2-dodecenoic acid (10:2) & 10:2 FTUA & $\mathrm{C} 12 \mathrm{H} 2 \mathrm{~F} 20 \mathrm{O} 2$ & 13C2-10:2 FTUA \\
\hline
\end{tabular}


Appendix 2. Recoveries of target analytes in 7-milliliter in-vessel spike tests of per- and polyfluorinated alkyl substances analyzed at the Colorado School of Mines, Golden, Colorado.

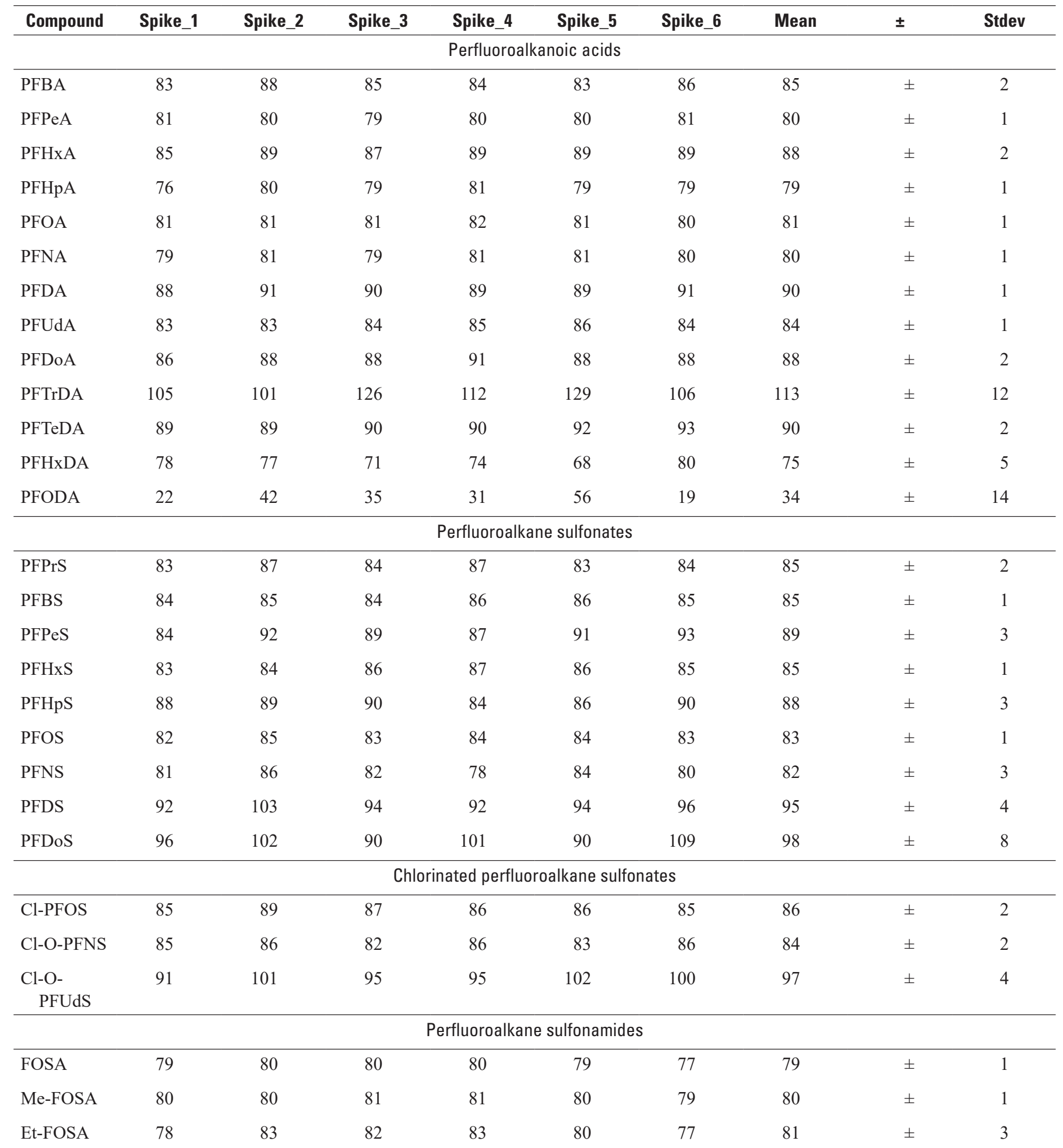


Appendix 2. 77

Appendix 2. Recoveries of target analytes in 7-milliliter in-vessel spike tests of per- and polyfluorinated alkyl substances analyzed at the Colorado School of Mines, Golden, Colorado.-Continued

\begin{tabular}{|c|c|c|c|c|c|c|c|c|c|}
\hline Compound & Spike_1 & Spike_2 & Spike_3 & Spike_4 & Spike_5 & Spike_6 & Mean & \pm & Stdev \\
\hline \multicolumn{10}{|c|}{ Perfluoroalkane sulfonamido acetic acids } \\
\hline FOSAA & 84 & 85 & 82 & 83 & 88 & 90 & 85 & \pm & 3 \\
\hline MeFOSAA & 86 & 88 & 88 & 88 & 89 & 89 & 88 & \pm & 1 \\
\hline EtFOSAA & 91 & 95 & 91 & 90 & 92 & 93 & 92 & \pm & 2 \\
\hline \multicolumn{10}{|c|}{ Fluorotelomer sulfonates } \\
\hline 4:2 FTS & 91 & 95 & 92 & 93 & 94 & 91 & 92 & \pm & 2 \\
\hline 6:2 FTS & 105 & 98 & 93 & 94 & 94 & 93 & 96 & \pm & 5 \\
\hline 8:2 FTS & 89 & 91 & 92 & 93 & 91 & 90 & 91 & \pm & 1 \\
\hline 10:2 FTS & 125 & 133 & 134 & 139 & 129 & 137 & 133 & \pm & 5 \\
\hline \multicolumn{10}{|c|}{ Fluorotelomer alkanoic acids } \\
\hline 6:2 FTA & 98 & 104 & 100 & 102 & 95 & 99 & 100 & \pm & 3 \\
\hline $8: 2$ FTA & 87 & 93 & 89 & 92 & 92 & 88 & 90 & \pm & 3 \\
\hline 10:2 FTA & 93 & 94 & 99 & 90 & 92 & 91 & 93 & \pm & 3 \\
\hline 3:3 FTA & 101 & 109 & 106 & 108 & 98 & 103 & 104 & \pm & 4 \\
\hline 5:3 FTA & 86 & 96 & 88 & 95 & 92 & 94 & 92 & \pm & 4 \\
\hline 7:3 FTA & 78 & 80 & 80 & 81 & 89 & 80 & 81 & \pm & 4 \\
\hline 6:2 FTUA & 94 & 96 & 95 & 93 & 93 & 96 & 95 & \pm & 2 \\
\hline $8: 2$ FTUA & 91 & 93 & 94 & 90 & 92 & 88 & 91 & \pm & 2 \\
\hline 10:2 FTUA & 95 & 88 & 92 & 92 & 91 & 94 & 92 & \pm & 2 \\
\hline
\end{tabular}


Appendix 3. Calibration range, limit of quantitation, linear fit $\left(r^{2}\right)$, and weighting type of calibration curves for target analytes of per- and polyfluorinated alkyl substances analyzed at the Colorado School of Mines, Golden, Colorado.

[ng/L, nanograms per liter]

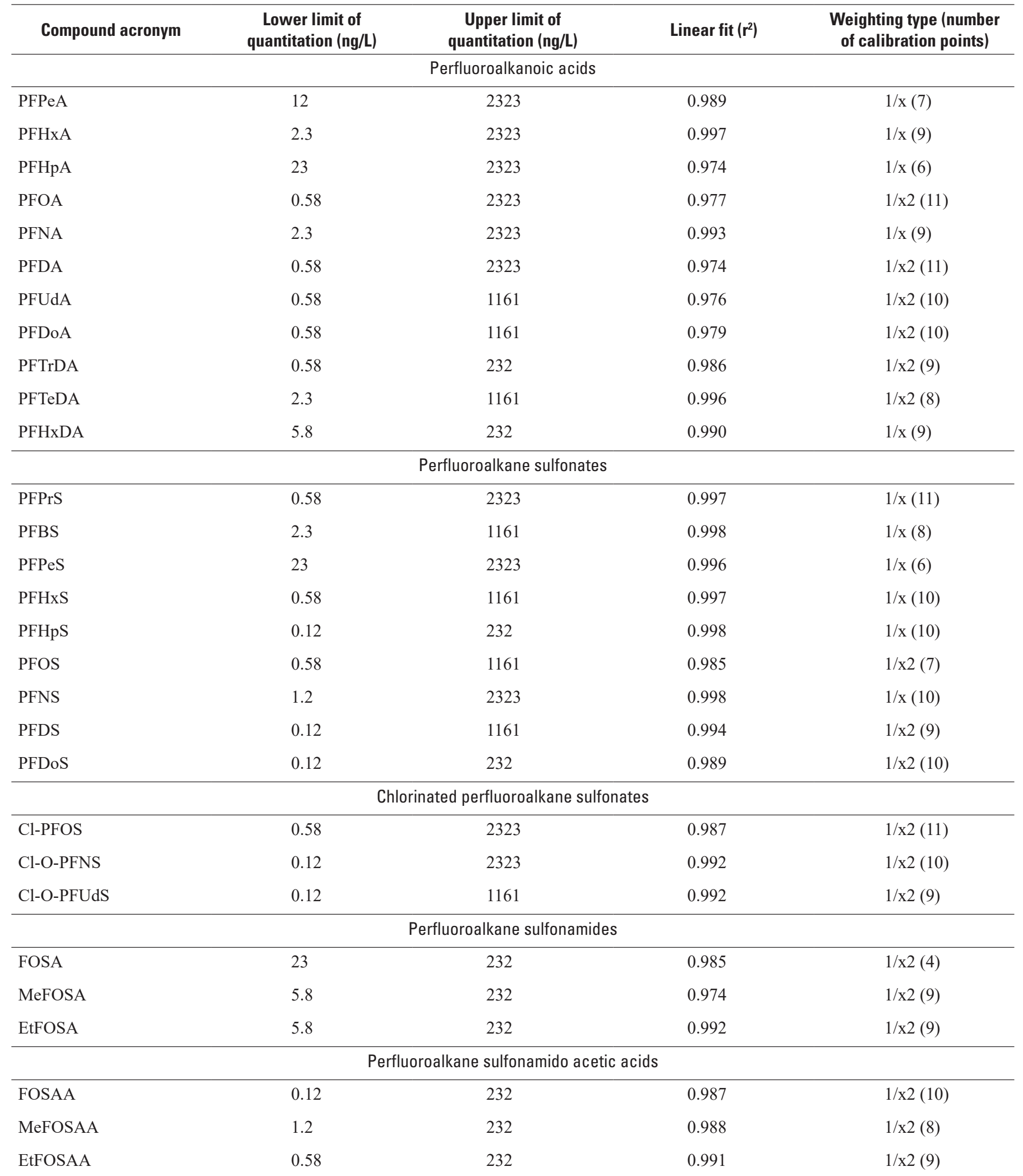


Appendix 3. Calibration range, limit of quantitation, linear fit $\left(r^{2}\right)$, and weighting type of calibration curves for target analytes of per- and polyfluorinated alkyl substances analyzed at the Colorado School of Mines, Golden, Colorado.—Continued

[ng/L, nanograms per liter]

\begin{tabular}{|c|c|c|c|c|}
\hline Compound acronym & $\begin{array}{c}\text { Lower limit of } \\
\text { quantitation (ng/L) }\end{array}$ & $\begin{array}{c}\text { Upper limit of } \\
\text { quantitation (ng/L) }\end{array}$ & Linear fit $\left(r^{2}\right)$ & $\begin{array}{l}\text { Weighting type (number } \\
\text { of calibration points) }\end{array}$ \\
\hline \multicolumn{5}{|c|}{ Fluorotelomer sulfonates } \\
\hline $6: 2$ FTS & 5.8 & 1161 & 0.996 & 1/x (10) \\
\hline $8: 2$ FTS & 1.2 & 2323 & 0.995 & $1 / x 2(10)$ \\
\hline \multicolumn{5}{|c|}{ Fluorotelomer alkanoic acids } \\
\hline 3:3 FTA & 12 & 2323 & 0.996 & $1 / x 2(7)$ \\
\hline 5:3 FTA & 1.2 & 1161 & 0.989 & $1 / x 2(9)$ \\
\hline 7:3 FTA & 0.58 & 232 & 0.985 & $1 / x 2(9)$ \\
\hline 10:2 FTA & 23 & 2323 & 0.999 & $1 / x(6)$ \\
\hline $6: 2$ FTUA & 0.58 & 2323 & 0.984 & $1 / x 2(11)$ \\
\hline $8: 2$ FTUA & 1.2 & 1161 & 0.994 & $1 / x 2(9)$ \\
\hline 10:2 FTUA & 2.3 & 232 & 0.994 & $1 / x 2(7)$ \\
\hline
\end{tabular}


